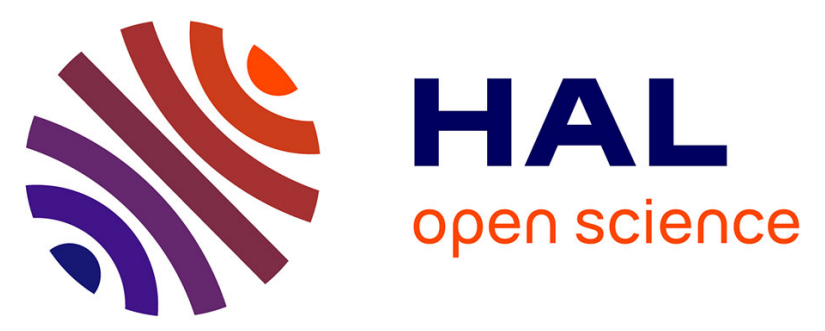

\title{
Mica composition as a vector to gold mineralization: Deciphering hydrothermal and metamorphic effects in the Malartic district, Quebec
}

Nicolas Gaillard, Anthony Williams-Jones, James Clark, Philip Lypaczewski, Stefano Salvi, Stephane Perrouty, Nicolas Piette-Lauzière, Carl Guilmette, Robert Linnen

\section{To cite this version:}

Nicolas Gaillard, Anthony Williams-Jones, James Clark, Philip Lypaczewski, Stefano Salvi, et al.. Mica composition as a vector to gold mineralization: Deciphering hydrothermal and metamorphic effects in the Malartic district, Quebec. Ore Geology Reviews, 2018, 95, pp.789-820. 10.1016/j.oregeorev.2018.02.009 . hal-02363124

HAL Id: hal-02363124

https://hal.science/hal-02363124

Submitted on 6 Nov 2020

HAL is a multi-disciplinary open access archive for the deposit and dissemination of scientific research documents, whether they are published or not. The documents may come from teaching and research institutions in France or abroad, or from public or private research centers.
L'archive ouverte pluridisciplinaire HAL, est destinée au dépôt et à la diffusion de documents scientifiques de niveau recherche, publiés ou non, émanant des établissements d'enseignement et de recherche français ou étrangers, des laboratoires publics ou privés. 


\title{
Mica composition as a vector to gold mineralization: Deciphering hydrothermal and metamorphic effects in the Malartic District, Québec
}

\begin{abstract}
Authors
Nicolas Gaillard ${ }^{1}$, Anthony E. Williams-Jones ${ }^{1}$, James R. Clark ${ }^{1}$, Philip Lypaczewski ${ }^{2}$, Stefano Salvi ${ }^{3}$, Stéphane Perrouty ${ }^{4}$, Nicolas Piette-Lauzière ${ }^{5}$, Carl Guilmette ${ }^{5}$, Robert L. Linnen ${ }^{4}$
\end{abstract}

\section{Affiliations}

${ }^{I}$ McGill University, Department of Earth and Planetary Sciences, 3450 University Street, Montréal, QC, H3A 0E8, Canada

${ }^{2}$ University of Alberta, Department of Earth and Atmospheric Sciences, Edmonton, AB, T6G 2E3, Canada

${ }^{3}$ Géosciences Environnement Toulouse (GET), Université Paul Sabatier, CNRS, Institut de Recherche pour le Développement, 14 avenue Edouard Belin, F-31400 Toulouse, France

${ }^{4}$ Western University, Department of Earth Sciences, 1151 Richmond Street, London, ON, N6A 6B7, Canada

${ }^{5}$ Université Laval, Département de Géologie et de Génie Géologique, Québec, QC, G1V 0A6, Canada

\section{Corresponding author}

Nicolas Gaillard

McGill University, Department of Earth and Planetary Sciences

3450 University Street, Montréal, QC, H3A 0E8, Canada

nicolas.gaillard@mail.mcgill.ca 


\section{Abstract}

Canadian Malartic, with a total endowment of $16.3 \mathrm{Moz} \mathrm{Au}$, is an important example of a largetonnage, low-grade Archean gold deposit (current reserves of $204 \mathrm{Mt} @ 1.08 \mathrm{~g} / \mathrm{t} \mathrm{Au}$ ). It is located in the southern Superior Province in contact with, and immediately south of the east-west trending CadillacLarder Lake fault zone, which delineates the boundary between the Pontiac and Abitibi subprovinces. The deposit is hosted by Pontiac Group metaturbidites, Piché Group mafic-ultramafic metavolcanics and by porphyritic quartz monzodiorite to granodiorite that intrude these lithologies. The metamorphic grade increases southward from upper greenschist facies, which characterizes the immediate metamorphic environment of the Canadian Malartic deposit, to mid-amphibolite facies; the garnet isograd is crossed 1.5 kilometers south of the deposit, and the staurolite isograd about one kilometer further south. Textural, structural and geochronological observations are consistent with a syn-kinematic $\left(\mathrm{D}_{2}\right)$, early- to syn-peak metamorphic $\left(\mathrm{M}_{2}\right)$ timing for the main ore-forming event.

Mineralization in the metasedimentary rocks and porphyritic intrusions consists of disseminated native 14 gold and minor gold-tellurides within stockworks of quartz-biotite-microcline-carbonate \pm pyrite veinlets 15 (v2) and associated microcline-albite-biotite \pm (white mica)-carbonate-pyrite pervasive alteration. A zonal distribution of alteration is centered on structures that acted as preferential pathways for the hydrothermal 17 fluids (e.g., Sladen Fault, NW-SE deformation zones). In metasedimentary rocks, the proximal potassic 18 alteration zone is dominated by microcline-albite \pm quartz with variable proportions of phlogopite ( \pm white mica), carbonate minerals (calcite-ankerite \pm Fe-dolomite), quartz, pyrite and rutile. It grades outwards into

20 a distal potassic-sericitic alteration zone characterized by relatively abundant $\mathrm{Mg}$-rich biotite and

21 phengitic white mica, as well as microcline, albite, quartz, calcite, pyrite and rutile. The zonal distribution 22 of alteration features was due in part to a decrease in the total activity of sulfur species $\left(\sum a \mathrm{~S}\right)$ and oxygen 23 fugacity $\left(f \mathrm{O}_{2}\right)$ away from the main hydrothermal corridors, which is manifested by systematic changes in 24 Fe-sulfide and (Fe-Ti)-oxide mineralogy.

25 The effects of sulfidation $\left(\sum a \mathrm{~S}\right)$, oxidation $\left(f \mathrm{O}_{2}\right)$ as well as $\mathrm{K}^{+}, \mathrm{Fe}^{2+}$ and $\mathrm{H}^{+}$activity on biotite and 26 white mica compositions were assessed from silicate-oxide-sulfide equilibria calculations. Increasing $27 \sum a \mathrm{~S}-f \mathrm{O}_{2}$ conditions proximal to the hydrothermal fluid pathways caused pyrite to be stabilized over 28 biotite, and iron sequestration in the sulfide phase in turn promoted the stability of magnesian biotite 29 compositions. Increasing sulfur metasomatism towards the hydrothermal centers was associated with 
systematic increases in biotite $\mathrm{Mg} \#\left[\mathrm{Mg} /\left(\mathrm{Fe}_{\text {total }}+\mathrm{Mg}\right)\right]$ and fluorine concentration, in agreement with the

31 Fe-F avoidance principle. Alteration was also associated with a decrease in Al in biotite and white mica,

32 coincident with increases in $\mathrm{Si}$ and $\mathrm{Fe}+\mathrm{Mg}$ concentrations. These compositional trends were controlled by

33 a Tschermak exchange reaction and are consistent with a gradual decrease in $a \mathrm{~K}^{+}$and/or $\mathrm{pH}$ upon

34 progressive rock-buffering of a mildly alkaline, potassium-rich ore-forming fluid.

35 In addition, multicomponent phase equilibria (pseudosections), constrained for specified bulk rock compositions typical of non-mineralized Pontiac Group metasedimentary rocks, are used to model the expected composition of mica solid solutions under varying metamorphic P-T conditions. The thermodynamic modelling of biotite and white mica compositions suggests that the district-scale compositional trends documented for biotite and white mica along the metamorphic gradient, including the progression of the Tschermak substitution towards more aluminous compositions southwards, were

41 likely the product of increasing metamorphic P-T conditions, rather than a distal effect of hydrothermal alteration.

Mica mineral chemistry is clearly a sensitive indicator of hydrothermal and metamorphic processes at Canadian Malartic. Our results show that biotite and white mica compositions provide a valuable tool to define hydrothermal fluid pathways in and around the deposit. These factors should be particularly useful for mapping the zonation of alteration features that characterize the footprint of major gold deposits in metamorphic terranes, where micas typically offer a good spatial distribution for defining mineralchemical vectors to ore.

\section{Keywords}

50 Canadian Malartic gold deposit; Mica mineral chemistry; Sulfidation-oxidation halo; Metamorphism; 51 Exploration vectors.

\section{Highlights}

53 - Mica composition records changes in physico-chemical conditions during alteration

$54-$ An increase in biotite $\mathrm{Mg} \#$ is associated with increasing $\sum a \mathrm{~S}-f \mathrm{O}_{2}$ conditions

55 - Tschermak exchange trends in altered rocks are controlled by variations in $a \mathrm{~K}^{+}$and/or $\mathrm{pH}$

56 - These parameters can be used to develop mineral-chemical vectors toward ore zones

57 - Mica compositional trends in non-altered rocks are caused by a metamorphic P-T increase 
Canadian Malartic, in the southeastern Superior Province of Canada, is a world-class example of a

60 low-grade, large-tonnage Archean gold deposit. It is located within, and immediately south of the

61 Cadillac-Larder Lake fault zone, which marks the boundary between the Abitibi and Pontiac subprovinces. The Abitibi greenstone belt hosts many well-studied deposits that have been used to develop genetic and exploration models for Archean gold deposits worldwide. Most of the gold deposits are located along two major structures, the Porcupine-Destor fault zone to the north and the CadillacLarder Lake fault zone to the south (Fig.1). Most of these deposits comprise relatively high gold grade quartz-carbonate \pm tourmaline veins (e.g., McIntyre-Hollinger, Sigma-Lamaque, Kirkland Lake) associated with carbonate-sericite \pm albite alteration (orogenic-type deposits; Robert and Poulsen, 1997; Goldfarb et al., 2005), but also include gold-rich volcanogenic massive sulfide (VMS) deposits such as Horne, Bousquet and La Ronde-Penna (Franklin et al., 2005). Canadian Malartic contrasts with these vein- and VMS-related deposits in that the gold is mainly disseminated, and is associated with microveinlet stockworks and microcline-albite-biotite-carbonate-pyrite \pm white mica alteration. The gold mineralization is also spatially associated with quartz monzodiorite to granodiorite porphyritic intrusions that crosscut the Pontiac Group metaturbidites and Piché Group mafic-ultramafic metavolcanics. On the basis of these features, as well as the inferred nature of the ore fluid, Canadian Malartic has been classified as an oxidized intrusion-related deposit (Helt et al., 2014), a definition that incorporates many of the characteristics of the syenite-associated disseminated gold deposit model of Robert (2001).

Epigenetic gold-dominated deposits formed at different stages during the tectonic evolution of the Abitibi greenstone belt. The syenite-associated deposits are genetically related to Timiskaming-age alkaline magmatism, and are commonly overprinted by a penetrative foliation associated with regional metamorphism (Robert, 2001). Quartz-carbonate vein systems, in contrast, generally formed during the main phase of crustal shortening (post-Timiskaming) under conditions close to peak metamorphism (McCuaig et al., 1998; Groves et al., 2003; Robert et al., 2005). The study of these Archean deposits thus represents a major challenge because of the superposition of deformation, hydrothermal and metamorphic events, and common overprinting of primary geological features. Canadian Malartic is such an example, as mineralogical, textural, as well as structural lines of evidence collectively suggest a syn-kinematic, early- to syn-peak metamorphic timing for the gold mineralization. 
Because mineral compositions record physico-chemical parameters of fluid-rock interaction (including temperature, pressure, $\mathrm{pH}, \mathrm{fO}_{2}$ and $\sum a \mathrm{~S}$ ) and metasomatic processes (e.g., halogen partitioning in micas) associated with the mineralization (Munoz, 1984, Mikucki and Ridley, 1993; Selby et al., 2000; Neumayr et al., 2008; Ayati et al., 2008; Bath et al., 2013; Pearce et al., 2015), this information can be used to develop vectors toward ore zones. In the case of Canadian Malartic, however, extracting such vectors poses a challenge because of the complex patterns that result from superposed hydrothermal, tectonic and metamorphic events.

In this paper, we report results of an investigation of mica mineral chemistry in hydrothermally altered metasedimentary rocks in order to provide insights into the ore-forming conditions at Canadian Malartic. Silicate-oxide-sulfide thermodynamic calculations have been conducted to assess the effects of sulfidation $\left(\sum a \mathrm{~S}\right)$, oxidation $\left(\mathrm{fO}_{2}\right)$ and activity of $\mathrm{K}^{+}, \mathrm{Fe}^{2+}$ and $\mathrm{H}^{+}$on biotite and white mica composition (cf. Froese, 1971; Nesbitt, 1986a,b; Zaleski et al., 1991; Hezarkhani et al, 1999; Spry, 2000; Rosenberg et al., 2000; Heiligmann et al., 2008). In addition, the composition of biotite and white mica in non-mineralized metasedimentary country-rock around the deposit was determined to assess the effect of metamorphism on the composition of these minerals and evaluate their potential utility as vectors toward mineralization. Multicomponent phase equilibria diagrams (pseudosections), constrained for specified bulk rock compositions typical of the metasedimentary host rocks, were calculated to model the expected composition of mica solid solutions under varying metamorphic P-T conditions. Our results demonstrate that biotite and white mica compositions provide a valuable tool to define fluid pathways in the hydrothermal system responsible for the formation of the Canadian Malartic deposit, and that it is possible to use these factors to map the distribution of alteration that defines the deposit footprint.

\section{Geological Background}

\subsection{Regional geology}

The Abitibi greenstone belt consists of a succession of volcano-stratigraphic units formed from

111 multiple episodes of tholeiitic to calc-alkaline, mafic-ultramafic to felsic volcanism and coeval plutonism, 112 ranging in age from 2750 to 2697 Ma (Figs.1-2; Ayer et al., 2002; Thurston et al., 2008). These volcanic 113 units are overlain by early turbidite-dominated metasedimentary sequences, including the Porcupine 114 assemblage, as well as Kewagama and Cadillac equivalents (Ayer et al., 2002; Thurston et al., 2008), 115 which were deposited between 2690 and 2685 Ma (Fig.1; Ayer et al., 2005). Greywackes and mudstones 
of the Pontiac Group ( 2682 Ma; Davis, 2002; Frieman et al., 2017) to the south, and of the Quetico

117 Group (2690-2687 Ma; Zaleski et al., 1999) to the north, formed extensive flyschoid belts that were

118 broadly coeval with Porcupine-type sedimentation. Alluvial-fluvial Timiskaming-type sediments (2677 to

1192670 Ma; Corfu et al., 1991; Ayer et al., 2005) were deposited unconformably on volcanic rocks or older

120 sedimentary assemblages, and are mostly confined to the Porcupine-Destor and Cadillac-Larder Lake

121 fault zones. The Timiskaming rocks constitute the youngest supracrustal assemblage in the southern

122 Abitibi belt (Fig.3; Thurston et al., 2008).

123 Syntectonic, pre-Timiskaming tonalite and granodiorite batholiths, as well as smaller porphyry plutons

124 of calc-alkaline affinity, were emplaced from 2697 to 2685 Ma (Fig.3; Corfu, 1993; Sutcliffe et al., 1993;

125 Davis et al., 2000), during the first episode of contractional deformation ( $\mathrm{D}_{1}$; Robert, 2001). Late

126 syntectonic intrusions and local extrusive equivalents were emplaced between 2681 and $2676 \mathrm{Ma}$, and

127 display a close spatial and temporal association with Timiskaming sedimentation (Davis et al., 2000;

128 Ayer et al., 2005). They include high-level plutons of sub-alkaline to alkaline magmatic affinity, ranging

129 in composition from monzodiorite and quartz monzonite to syenite (Feng and Kerrich, 1992; Sutcliffe et

130 al., 1993), some of which are genetically related to gold mineralization (Robert, 2001). Late-tectonic

131 igneous activity is represented by biotite-muscovite S-type granite intrusions (e.g., Lamotte and Preissac-

132 Lacorne monzogranite) and pegmatite, between 2670 and 2645 Ma (Ducharme et al., 1997; Davis et al.,

133 2000; Ayer et al., 2002).

134 A regional, post-Timiskaming, sub-greenschist (prehnite-pumpellyite) to amphibolite-facies

135 metamorphic event affected all supracrustal units in the southern Abitibi and northern Pontiac

136 subprovinces (Fig.3; Jolly, 1980; Dimroth et al., 1983b). This metamorphic event occurred between 2677

137 and $2643 \mathrm{Ma}$ (Powell et al., 1995), and corresponds broadly to a major phase of deformation (Wilkinson

138 et al., 1999) that involved regional north-south compression and local strike-slip transpression $\left(\mathrm{D}_{2}\right.$;

139 Daigneault et al., 2002), and later dextral transcurrent deformation along major fault zones $\left(\mathrm{D}_{3}\right)$. The main

140 deformation event $\left(\mathrm{D}_{2}\right)$ produced upright folds $\left(\mathrm{F}_{2}\right)$, with concurrent development of an axial-planar

141 penetrative schistosity, local thrusts and the overall east-west trending architecture of the Abitibi

142 greenstone belt (Robert, 2001). Contact metamorphic aureoles, which consist mainly of lower

143 amphibolite facies assemblages, occur adjacent to syn-volcanic and syn- to late-tectonic intrusions; they

144 are interpreted to have formed pre- to post-regional metamorphism (Thompson, 2005; Robert, 2005). 
There were several gold mineralization events during the evolution of the Abitibi greenstone belt, the chronological distribution of which is correlated to the complex succession of volcano-magmatic, tectonic

147 and metamorphic events (Fig.3). Gold-rich VMS deposits formed during the late stages of bimodal 148 volcanism (e.g., La Ronde-Penna, at 2698 Ma; Mercier-Langevin et al., 2007) and pre-date regional 149 episodes of deformation. Many intrusion-associated disseminated-stockwork gold deposits (e.g., syenite150 associated deposits; Robert, 2001) are genetically related to Timiskaming-age (2677 to 2670 Ma; Ayer et 151 al, 2005) alkaline magmatism. By contrast, mineralization usually characterized as 'orogenic' occurred 152 during two distinct events. Most of this mineralization, represented by the quartz-carbonate vein systems 153 of the Timmins-Val d'Or gold belt, formed during regional $\mathrm{D}_{2}$ deformation and is post-Timiskaming in 154 age (Robert et al., 2005). However, an early gold mineralization event (Couture et al., 1994), interpreted 155 to be associated with pre-metamorphic magmatic-hydrothermal activity, has been documented for the 156 Norlartic (>2692 Ma) and Kiena (>2686 Ma) deposits of the Val d'Or camp (Pilote et al., 1993; Morasse 157 et al., 1995).

\subsection{District-scale geology}

\subsubsection{Lithological units}

The Canadian Malartic deposit is hosted mainly by three lithologies (Fig.2), namely metaturbidites of the Pontiac Group (Sladen, Canadian Malartic and Gouldie orebodies), mafic to ultramafic metavolcanic rocks of the Piché Group (Barnat and East Malartic orebodies), and porphyritic quartz monzodiorite to granodiorite intrusions that crosscut all these lithologies (Trudel and Sauvé, 1992; Helt el al., 2014). The

164 Pontiac Group forms the northernmost domain of the Pontiac Subprovince, and consists of flyschoid 165 sequences of greywacke to mudstone interlayered with minor, local mafic-ultramafic volcanic flows and rare iron formation (Fig.2; Camiré and Burg, 1993; Camiré et al., 1993a; Benn et al., 1994; Ghassemi,

167 1996). The pelitic wackes of the Pontiac Group display well-preserved primary sedimentary textures,

168 including erosional bases, graded-bedding, as well as load casts and flame structures. Cyclical alternations 169 of mudstone to greywacke beds, ranging in thickness from a few millimetres to about one metre, define 170 partial Bouma sequences, typical of turbiditic sedimentation (Card and Poulsen, 1998). These sequences 171 are interpreted to have developed in the context of a fore-arc accretionary wedge complex (Dimroth et al., 172 1983a; Card, 1990) or as a syn-orogenic foreland basin formed during uplift related to collision or 173 shallow-angle subduction (Kimura et al., 1993; Camiré and Burg, 1993). 
The Piché Group consists of a narrow band (generally $<1 \mathrm{~km}$ wide) of schistose volcanics that are spatially restricted to the Cadillac-Larder Lake fault zone (Gunning and Ambrose, 1943; Simard et al., 2013). In the Malartic district, these rocks include variably strained blue-grey komatiites and tholeiitic basalts, as well as their talc-chlorite-carbonate altered equivalents (Sansfaçon, 1986).

Felsic, borderline sub-alkaline (calc-alkaline) to alkaline feldspar-phyric intrusions, ranging from quartz monzodiorite (Sladen, Barnat, East Malartic zones) to granodiorite (Gouldie zone), crosscut the Pontiac and Piché group rocks (Trudel and Sauvé, 1992; Helt el al., 2014). Quartz monzodiorite in the Sladen Zone (Fig.4) is characterized by plagioclase and minor orthoclase phenocrysts (typically $<6 \mathrm{~mm}$ in length) in a groundmass of quartz, plagioclase, biotite and chlorite with minor epidote, apatite, magnetite, titanite and zircon. These intrusions were emplaced at 2677-2679 Ma (De Souza et al., 2016; Clark et al., in prep.), synchronous with Timiskaming sedimentation to the north of the Cadillac-Larder Lake fault zone (2677.7 $\pm 0.8 \mathrm{Ma}$; Pilote et al., 2014). In the Malartic camp, these intrusions occur as structurallycontrolled, elongated stocks and dykes of limited width (usually $<100$ meters). Numerous mafic dykes and sills $(<1$ meter wide) intruded the Pontiac Group rocks and are interpreted by Camiré et al. (1993b) to be metamorphosed Mg-rich lamprophyres.

The Pontiac Group is bounded to the south by a granitoid-gneiss plutonic domain, which includes a pre- to syn-tectonic tonalitic suite (e.g., the Lac des Quinze batholith; Card and Poulsen, 1998), a syn- to late-tectonic (2685-2671 Ma) I-type monzodiorite-monzonite-granodiorite suite (e.g., the Lac Fréchette complex, the Lac Fournière pluton; Davis, 2002) and a late-tectonic (2670-2645 Ma) S-type garnetmuscovite granitic suite (e.g., the Decelles batholith; Feng et al., 1993; Mortensen and Card, 1993). The last of these is interpreted to have formed from the partial melting of Pontiac Group metasedimentary rocks (Feng and Kerrich, 1992).

\subsubsection{Structural and metamorphic setting}

The Pontiac Group displays a complex south- to southeast-vergent fold and thrust architecture that results from polyphase compressive deformation (Fig.3; Goulet, 1978; Sansfaçon and Hubert, 1990; Camiré and Burg; 1993; Benn et al., 1994; Ghassemi, 1996; Perrouty et al., 2017). The first deformation event $\left(\mathrm{D}_{1}\right)$ is represented by a series of NE-SW trending isoclinal anticlines and synclines $\left(\mathrm{F}_{1}\right)$ and a weak penetrative axial planar schistosity $\left(\mathrm{S}_{1}\right)$ (Fig.5A-B; Sansfaçon, 1986). The $\mathrm{F}_{1}$ folds are usually obscured by subsequent deformation (namely $\mathrm{D}_{2}$ ) and are rarely observed in the vicinity of the deposit, though they 
are inferred from local polarity inversions (Perrouty et al., 2017). The $\mathrm{S}_{1}$ foliation is a poorly-preserved,

204 discrete fabric defined by preferential alignment of relict biotite crystals, which is most evident in $\mathrm{F}_{2}$ fold

205 hinges where it occurs at a high angle to the $\mathrm{S}_{2}$ foliation (Fig.5B; Fallara et al., 2000). The second

206 deformation event $\left(\mathrm{D}_{2}\right)$ is manifested by a series of NW-SE oriented (N115 to N135), upright S-shaped

207 folds $\left(\mathrm{F}_{2}\right)$ with fold axes plunging to the $\mathrm{SE}$ (Fig.5C). The long limbs of the $\mathrm{F}_{2}$ folds strike approximately

208 E-W and dip steeply to the north, whereas their short limbs strike approximately N-S (Sansfaçon and

209 Hubert, 1990; Trudel and Sauvé, 1992). Folding was associated with a regionally pervasive axial-planar

$210 \mathrm{~S}_{2}$ foliation (Fig.5D) defined by the preferential alignment of biotite, white mica, chlorite and elongated

211 pyrrhotite-pyrite aggregates. The $\mathrm{S}_{2}$ foliation is the most prominent structural feature of the Pontiac

212 Group in the Malartic area and strikes roughly parallel to the Cadillac-Larder Lake fault zone. It is

213 interpreted to have developed early during the $\mathrm{M}_{2}$ regional tectono-metamorphic event (prior to peak

214 metamorphic conditions, as discussed below).

215 The $\mathrm{M}_{2}$ metamorphic assemblages are typical of a Barrovian sequence (Jolly, 1978; Camiré and Burg, 216 1993; Piette-Lauzière, 2017). The metamorphic grade increases southward from upper greenschist (at the 217 contact with the Cadillac-Larder Lake fault zone) to mid-amphibolite facies; the garnet isograd is crossed

2181.5 kilometers south of the deposit and the staurolite isograd occurs about one kilometer further south

219 (Fig.2). These isograds are essentially parallel to the $\mathrm{S}_{2}$ fabric and to the Cadillac-Larder Lake fault zone, 220 which further indicates that $\mathrm{D}_{2}$ deformation and prograde metamorphic recrystallization were broadly

221 contemporaneous (Fig.2). Peak metamorphic conditions in the metasedimentary rocks are indicated by the

222 occurrence of almandine-rich garnet and staurolite (Fig.5E-F). Cordierite may occur locally in the

223 Malartic district as subhexagonal porphyroblasts that have been pseudomorphed by white mica (Fig.5G).

224 Garnet occurs as euhedral (dodecahedral) to rounded crystals, some of which can be found as inclusions

225 in randomly oriented staurolite poikiloblasts (Fig.5E). The latter host linear trails of quartz and minor

226 biotite inclusions that define an internal foliation $\left(\mathrm{S}_{\mathrm{i}}\right)$, which is identical to and continuous with the main

$227 \mathrm{~S}_{2}$ foliation, indicating their late- to post-kinematic formation with respect to $\mathrm{D}_{2}$. Peak metamorphism is

228 thus considered to have been late- to post-D 2 (Fig.3; Piette-Lauzière, 2017). A late, N100-trending

229 cleavage $\left(\mathrm{S}_{2}{ }^{\prime}\right)$ is observed locally in finer-grained, more aluminous metasedimentary rocks (Trudel and

230 Sauvé, 1992; Desrochers and Hubert, 1996; Piette-Lauzière, 2017), and is characterized by crenulation 
and micro-folding of previous fabrics, and locally by the rotation of syn-kinematic staurolite poikiloblasts containing spiral inclusion trails (Fig.5E), which may indicate a shear component for late $\mathrm{D}_{2}$ deformation.

Late stage deformation $\left(\mathrm{D}_{3}\right)$ is expressed through minor chevron folds as well as N045- and N330oriented kink bands (Trudel and Sauvé, 1992; Fallara et al., 2000), and does not significantly overprint earlier fabrics. Retrograde metamorphism was recorded by local chloritization of biotite, and by white mica pseudomorphs after staurolite.

\subsection{Distribution and structural controls of gold mineralization}

The Canadian Malartic deposit is currently the largest operating gold mine in Canada with an annual production of $\sim 585,000 \mathrm{oz} \mathrm{Au}$ (in 2016) from an open pit that was commissioned in 2011. Since then, mining operations have produced a total of 2.75 Moz Au (and 2.6 Moz Ag) with estimated total proven and probable reserves of $204 \mathrm{Mt} @ 1.08 \mathrm{~g} / \mathrm{t}$ Au or a total of $7.1 \mathrm{Moz}$ Au (as of December 31, 2016; Agnico-Eagle 2016 annual report). Between 1935 and 1983, the area produced 5.1 Moz Au at an average grade of $4.5 \mathrm{~g} / \mathrm{t}$, from four underground mines. The orebodies exploited by these mines collectively define a >3.5 kilometer long mineralized system including, from west to east, the Canadian Malartic (9.93 Mt@ $3.37 \mathrm{~g} / \mathrm{t}$ Au historic production), Sladen(3.90 Mt@2.43 g/t Au), Barnat (4.55 Mt @6.20 g/t Au) and East Malartic (17.95 Mt@ 4.92 g/t Au) deposits (Fig.4; Sansfaçon et al., 1987a,b; Trudel and Sansfaçon, 1987; Trudel and Sauvé, 1992). The overall endowment of the deposit is estimated at 16.3 Moz Au, based on proven and probable reserves, measured and indicated resources, plus historic and recent production.

Gold mineralization in the current Canadian Malartic mine area is associated with a broad zone of disseminated pyrite defining a semi-continuous halo of low-grade gold (0.3-1 g/t Au) enveloping variably developed, higher-grade (generally $>1 \mathrm{~g} / \mathrm{t} \mathrm{Au}$ ) stockworks, replacement zones and local breccias. Elongated, lens-shaped orebodies are controlled by second-order structures (Fig.4) that are interpreted to have been the main pathways for hydrothermal fluids. These structures include the E-W trending Sladen Fault, a $>3$ kilometer-long subvertical to south-dipping ductile-brittle shear zone, which marks the contact between the metasedimentary rocks and the main porphyry stock in the western part of the deposit, and delineates the Piché-Pontiac contact in the east. It is usually defined by a narrow zone of mylonite $(<5$ meters thick) variably overprinted by brittle faulting characterized by local brecciation, cataclasite and gouge (De Souza et al., 2016). Controlling structures also include NW-SE trending, north-dipping deformation zones that comprise faulted asymmetric $S$-shaped $F_{2}$ folds, the axial planes of which are 
parallel to the $\mathrm{S}_{2}$ foliation ( N110). The fold hinges consist locally of high-strain zones that contain fault-

261 fill (shear) quartz-dominated veins, sub-orthogonal to the sedimentary bedding (e.g., in the Gilbert and

262 Gouldie zones; De Souza et al., 2016). In addition, the WNW-ESE trending Barnat Fault, a 200 meter

263 wide anastomosed deformation corridor within the Cadillac-Larder Lake fault zone marks the contact

264 between the Piché (to the northeast) and Pontiac (to the southwest) groups (Derry, 1939; Sansfaçon, 1986;

265 Trudel and Sauvé, 1992). This fault is manifested by intense shearing of ultramafic to mafic talc-chlorite-

266 carbonate schists and fracturing of more competent porphyritic quartz monzodiorite and diorite intrusions

267 (Sansfaçon et al., 1987b).

\subsection{Whole-rock analysis}

A suite of 596 metasedimentary rock samples was analyzed for whole-rock major and trace element compositions. The samples were prepared using a combination of crushing, splitting and pulverizing

272 (with mild steel). Major element concentrations were determined using XRF analysis on lithium 273 metaborate-tetraborate fused glass by Actlabs, Ontario. Minor and trace element concentrations were 274 measured using a combination of ICP-AES and -MS after sodium peroxide fusion by SGS, British 275 Columbia. Trace element concentrations, including gold, were also measured by ALS, British Columbia, 276 using ICP-MS after digestion by aqua regia. Carbon and sulfur concentrations were determined by SGS 277 using IR combustion. Quality control involved systematic analysis (every 20 samples) of internal 278 standards and blanks, as well as certified reference material USGS SDC-1 (Flanagan, 1976).

279 Fluoride and chloride concentrations were determined by ion-selective electrode analysis using a 280 Mandel Scientific PC-Titrate automated titration system (Geoscience Laboratories, Ontario Geological

281 Survey). Sample preparation utilized fusion of $\sim 1.0 \mathrm{~g}$ of pulverized material mixed with sodium carbonate 282 (Pamer, 2013). The resulting glass was dissolved in deionized water and the $\mathrm{pH}$ of the solution was 283 adjusted to 5.5 for the fluoride analysis and to less than 4 for the chloride analysis, using citric and nitric 284 acids, respectively. The ionic strength of the solution was buffered using a mixture of organic compounds 285 for the fluoride analysis, and sodium nitrate for the chloride analysis. Concentrations of fluoride and 286 chloride were measured after diffusion of the analytes through an electrode ion-selective membrane. 


\subsection{Electron microprobe analysis}

The chemical compositions of micas were determined using a JEOL JXA-8900L Electron Probe Microanalyzer at the Department of Earth and Planetary Sciences, McGill University. The analyses were carried out using wavelength-dispersive spectrometry with a $5 \mu \mathrm{m}$ beam diameter, a $15 \mathrm{kV}$ accelerating voltage and a $20 \mathrm{nA}$ beam current. Standard reference materials, including albite (Na), orthoclase (K, Al), diopside ( $\mathrm{Si}, \mathrm{Mg}, \mathrm{Ca})$, hematite $(\mathrm{Fe})$, rutile (Ti), spessartine $(\mathrm{Mn})$, chromite $(\mathrm{Cr})$, zircon $(\mathrm{Zr}), \mathrm{Ba}-$ orthoclase $(\mathrm{Ba})$, fluorite $(\mathrm{F})$ and vanadinite $(\mathrm{Cl})$ were systematically measured for calibration and internal consistency between analytical sessions. Peak counting times during quantitative analyses were $20 \mathrm{~s}$ for $\mathrm{Si}, \mathrm{Al}, \mathrm{Fe}, \mathrm{Mg}, \mathrm{K}, \mathrm{Na}$, Ti and $\mathrm{Mn}$; $40 \mathrm{~s}$ for $\mathrm{Cl}$ and $\mathrm{Ca} ; 80 \mathrm{~s}$ for $\mathrm{Ba}$ and $\mathrm{Zr}$; and $100 \mathrm{~s}$ for $\mathrm{F}$. Average lower limits of detections were $0.13 \mathrm{wt} \%$ for fluorine and $0.01 \mathrm{wt} . \%$ for chlorine.

\subsection{Hyperspectral imaging}

Shortwave infrared (SWIR: 1000-2500 nm) reflectance spectra were acquired on drill-core samples using a Specim SisuROCK ${ }^{\mathrm{TM}}$ hyperspectral imaging system (Lypaczewski et al, in prep.). The hyperspectral camera resolution for drill core imaging was $1 \mathrm{~mm}$ per pixel, with each pixel attributed an infrared reflectance spectrum. In the SWIR domain, phyllosilicates display characteristic absorption features that are mainly affected by the interactions between the octahedrally-coordinated cations and the hydroxyl $\left(\mathrm{OH}^{-}\right)$group (Hunt, 1977; Clark et al., 1990). For example, the Al-OH bond of white mica produces an absorption around $\sim 2200 \mathrm{~nm}$, and the $\mathrm{Al}(\mathrm{Mg}, \mathrm{Fe})-\mathrm{OH}$ bond of biotite produces an absorption around $2250 \mathrm{~nm}$. Substitutions involving octahedral site cations are thus responsible for subtle shifts in the position of the absorption wavelength of phyllosilicates (McLeod et al., 1987; Duke, 1994). The biotite $\mathrm{Mg} \#$ (i.e., atomic $\mathrm{Mg} /[\mathrm{Mg}+\mathrm{Fe}]$ ) and the white mica $\mathrm{Al}^{\mathrm{VI}}$ content were estimated by calibrating the spectral data (wavelength position of the cation-OH band) with quantitative electron microprobe analyses (Lypaczewski and Rivard, in prep.).

\section{Hydrothermal Alteration and Gold Mineralization}

\subsection{Vein paragenesis}

It is evident from the superposition of multiple episodes of veining that Canadian Malartic has had a complex hydrothermal history (Derry, 1939; Helt et al., 2014; De Souza et al., 2016). In this section, we use a simplification of the vein nomenclature introduced by De Souza et al. (2016). The earliest veins (v1) 
315 pre-date gold mineralization, are a few centimeters wide (commonly $<5 \mathrm{~cm}$ ) and consist mainly of quartz

316 with lesser albite and traces of pyrite \pm galena. These veins are cut by thin $(<1 \mathrm{~cm})$ ore-stage quartz-biotite-

317 calcite $\pm($ Fe-carbonate)-microcline-pyrite veinlets (v2) with narrow ( $<5 \mathrm{~mm})$ biotite \pm (calcite-microcline-

318 pyrite) selvages (Figs.6-7). Native gold and Au-bearing tellurides occur within v2 veinlets and alteration

319 envelopes in associated stockworks and pervasive alteration zones. In the NW-SE deformation zones

320 (e.g., the Gilbert and Gouldie zones), quartz-dominated fault-fill sheeted veins (up to 1 meter in width)

321 typically occur at a high angle to the sedimentary bedding in sheared $F_{2}$ fold hinges (De Souza et al.,

322 2016). These veins contain the same mineral assemblage and are associated with similar alteration

323 features as the v2 veinlets; they are interpreted to be part of the same hydrothermal event. Main-stage

324 stockwork veinlets (v2) and fault-fill veins preferentially occur parallel to the $\mathrm{S}_{2}$ foliation (e.g., in $\mathrm{F}_{2}$ fold

325 hinges; Fig.7B-C) but are locally deformed and transposed by the $\mathrm{D}_{2}$ event; we interpret these veins to

326 have formed early- to syn-D 2 (Fig.3). Coarse-grained veins (v3), historically referred to as 'pegmatitic'

327 (Derry, 1939), cut the v2 veinlets and related alteration and represent a marginal type of mineralization.

328 They are, for the most part, restricted to the porphyritic quartz monzodiorite intrusions along the Sladen

329 Fault. The v3 veins consist of quartz, albite, white mica, orthoclase, carbonate minerals, tourmaline,

330 rutile, pyrite and native gold (Derry, 1939; De Souza et al., 2016). In the porphyritic intrusions, v3 veins

331 have a pink alteration halo (up to one meter wide) associated with the replacement of biotite by

332 microcline-white mica-quartz-carbonates-pyrite-rutile \pm hematite. Shallow-dipping extensional quartz

333 veins (v4) are inferred to have been associated with late movement along the Sladen Fault and postdated

334 gold mineralization. Barren chlorite-calcite veinlets $(<1 \mathrm{~mm})$ are associated with $\mathrm{D}_{3}$ kink-bands (v5) and

335 crosscut all earlier sets of veins.

\subsection{Hydrothermal alteration}

Disseminated gold mineralization at Canadian Malartic occurs within stockworks of quartz-biotite-

338 microcline-carbonate \pm pyrite veinlets (v2) and associated microcline-albite-biotite \pm (white mica)-

339 carbonate-pyrite pervasively altered wall-rocks (Figs.6-10; Helt et al., 2014). A lateral zonation adjacent

340 to the main fluid pathways (e.g., Sladen and Barnat faults, NW-SE deformation zones) is evident from

341 systematic variations in the hydrothermal alteration assemblage (Fig.8; De Souza et al., 2016). This

342 alteration sequence is typified by proximal potassic (microcline \pm albite-phlogopite) and distal potassic-

343 sericitic (biotite-phengite-microcline \pm albite) assemblages (Fig.11). Extensive pyritization, carbonatization 
344 (from proximal calcite-ankerite to distal calcite-only) and albitization, as well as local silicification and retrograde chloritization are prominent features of the alteration.

346 Proximal alteration is characterized by a yellowish/brown (in metasedimentary rocks) to

347 beige/pinkish-colored (in quartz monzodiorite) replacement assemblage that obliterates primary host-rock

348 textures (Fig.6). It extends a few meters to a few tens of meters in width and is generally asymmetrical

349 around the main hydrothermal corridors. Proximal alteration is typically associated with dense stockwork

350 veining where it forms a halo adjacent to ore-stage quartz-biotite-carbonate-microcline \pm pyrite (v2)

351 veinlets (Fig.6A-B). These veinlets locally crosscut (Fig.6E), but spatially coincide with zones of

352 pervasive microcline-albite \pm quartz replacement. A hydrothermally-cemented, open-space filled

353 stockwork breccia is commonly associated with zones of intense ore-stage veining (Fig.6A; Beaulieu et

354 al., 2010; Helt et al, 2014). The innermost proximal alteration facies is dominated by a narrow zone $(<5$

$355 \mathrm{~m}$ ) of highly strained pervasively altered rocks (replacement-type), which typically delineates the

356 structures that acted as pathways for hydrothermal fluids. In the Sladen Fault zone, the latter is defined by

357 a strongly foliated mylonitic fabric, which suggests a syn-kinematic timing of hydrothermal alteration

358 with respect to ductile deformation (Fig.6-C; Fallara et al., 2000; De Souza et al., 2016). In

359 metasedimentary rocks and quartz monzodiorite, the mineralogy of the proximal alteration assemblage is

360 dominated by very fine-grained $(<10 \mu \mathrm{m})$ microcline-albite \pm quartz with variable proportions of

361 phlogopite ( \pm white mica), carbonate minerals (calcite-ankerite $\pm F e-d o l o m i t e), ~ q u a r t z$, pyrite and rutile

362 (Fig.6D-I). Phlogopite, carbonate minerals and quartz occur mainly within ore-stage veinlet (v2)

363 alteration envelopes, and as stringers that formed interstitially between patches of microcrystalline

364 microcline-albite replacement (Fig.6E-H). Pyrite occurs as coarse euhedra (usually $<2 \mathrm{~mm}$ ) in these

365 stringers as well as fine disseminations in the groundmass. Hematite is restricted to the quartz

366 monzodiorite intrusions where it is closely associated with pyrite (Figs.9B and 11).

367 The proximal alteration grades outwards into a distal alteration envelope dominated by biotite-

368 phengite-microcline \pm albite-calcite-pyrite (Fig.7), typically tens to hundreds of meters in width. The

369 intensity of the distal alteration correlates with the density of ore-stage quartz-biotite-microcline-

370 carbonate \pm pyrite stockwork veinlets (v2) and decreases progressively away from the hydrothermal fluid

371 pathways. Distal alteration in metasedimentary rocks is characteristically blue/grey in color, which is

372 attributed to abundant phengitic white mica and Mg-rich biotite (Fig.7A-C), and also includes microcline, 
albite, quartz, calcite, pyrite, rutile and apatite. Increasing proximity to v2 veinlets is associated with progressive replacement of the host-rock plagioclase $\left(\mathrm{An}_{25-30}\right)$ by fine-grained microcline and albite (Fig.7C-E). Distal alteration was partly controlled by variations in grain-size and protolith composition. Sericitization was best developed in mudstone layers because of the more aluminous composition of the latter relative to the coarser-grained greywacke (Fig.7H-J). In quartz monzodiorite, distally-altered rock is medium grey (Fig.7D) and changes progressively to a light-pink/beige color in the vicinity of v2 and v3 veins. This alteration consists of a biotite-albite-microcline-white mica-quartz-calcite-pyriterutile \pm hematite \pm barite assemblage, which typically occurs as patchy aggregates and stringers interstitially to albite-, microcline-, and sericite-altered feldspar phenocrysts.

\subsection{Distribution of sulfide-oxide minerals}

The zonal distribution of alteration was associated with a decrease in the total activity of sulfur species $\left(\sum a \mathrm{~S}\right)$ and oxygen fugacity $\left(f \mathrm{O}_{2}\right)$ away from the main hydrothermal corridors. These variations are manifested by systematic changes in Fe-sulfide and (Fe-Ti)-oxide mineralogy (Figs.9 and 11), which were used as a framework for monitoring changes in physico-chemical conditions and ore-forming processes (cf. Nesbitt and Kelly, 1980; Nesbitt, 1986a,b; Spry, 2000; Neumayr et al., 2008; Helt et al., 2014). Altered rocks within the ore shell contain pyrite and rutile as the main Fe-sulfide and oxide phases, indicating relatively elevated sulfidation and oxidation conditions for mineralization (Fig.9A; Helt et al., 2014). In contrast, metasedimentary rocks beyond the ore shell are characterized by the assemblage pyrite-pyrrhotite-ilmenite \pm magnetite \pm (graphite), which is interpreted to have formed under relatively reduced conditions during the prograde metamorphism (Figs.9, 11; Pitcairn et al., 2006). The appearance of fine-grained, subhedral to euhedral pyrite represents the most distal apparent mineralogical indicator of alteration associated with gold mineralization and delineates the outermost extent of the sulfidationoxidation halo (Fig.12A). Pyrite in metasedimentary rocks beyond the ore shell is commonly aligned in the main foliation $\left(\mathrm{S}_{2}\right)$ and shows increasing degrees of replacement by pyrrhotite \pm (chalcopyritepentlandite) with increasing metamorphic grade southwards (Fig.9C-D). Rutile (and titanite) replace ilmenite in hydrothermally-altered metasedimentary rocks and its distribution coincides with the pyriteonly side of the pyrite-pyrrhotite transition at the edge of the ore shell (Fig.11).

In the quartz monzodiorite, the oxidation-sulfidation gradient is manifested by the progressive replacement and overgrowth of magnetite by pyrite+hematite towards the ore zone (Fig.9B). Igneous 
titanite was pseudomorphed by rutile \pm (calcite-hematite-pyrite) in hydrothermally-altered rocks (Fig.9E), which is interpreted to have been controlled mainly by an increase in $\mathrm{X}\left(\mathrm{CO}_{2}\right)$ towards the hydrothermal fluid pathways (Clark et al., 1989). The fact that hematite and sulfate minerals are restricted to quartz monzodiorite (pyrite-rutile-hematite \pm barite/celestite) suggests that oxygen fugacity was internally (rock) buffered and that values of $f \mathrm{O}_{2}$ were higher (above the magnetite-hematite buffer) in the intrusions than in the adjacent metasediments (Fig.11; Helt et al., 2014). This observation raises the possibility that the intrusions played a pivotal role in channelling oxidized hydrothermal fluids throughout the mineralized system (e.g., Bath et al., 2013).

\subsection{Gold mineralization and relationship with pyrite}

Gold mineralization at Canadian Malartic occurs mainly in the form of native gold grains (generally $<10 \mu \mathrm{m}$ in diameter) and minor $\mathrm{Au}-(\mathrm{Ag}-\mathrm{Bi}-\mathrm{Pb})$-bearing tellurides, including petzite $\left(\mathrm{Ag}_{3} \mathrm{AuTe}_{2}\right)$, hessite $\left(\mathrm{Ag}_{2} \mathrm{Te}\right)$, calaverite $\left(\mathrm{AuTe}_{2}\right)$ and altaite $(\mathrm{PbTe})$ (Fig.10; Helt et al., 2014). These minerals are associated with pyrite in ore-stage veinlets (v2), in alteration envelopes surrounding these veinlets and in zones of pervasive alteration. Native gold and the telluride minerals occur as inclusions and fracture-fillings in pyrite, along pyrite-pyrite grain boundaries, and with silicates and carbonates close to pyrite grains (Fig.10A-E). Hydrothermal pyrite in the ore shell is characteristically zoned (Fig.10A-B; Gao et al., 2015) and, for simplicity, can be subdivided texturally into two generations. Early pyrite $\left(\mathrm{H}_{1}\right)$ is rich in inclusions (including biotite, microcline, albite, carbonates, rutile) and forms the cores of crystals; it is typically overgrown by late, inclusion-free pyrite $\left(\mathrm{H}_{2}\right)$. Pyrite $\mathrm{H}_{1}$ is characterized by higher Au-Ag-Bi-Te$\mathrm{Sb}-\mathrm{Pb}-\mathrm{Zn}$ concentrations than $\mathrm{H}_{2}$, and displays complex oscillatory zonations that are manifested by rhythmic variations in Ni concentrations (Gaillard et al., in prep.). Inclusions of native gold and Au-(Ag)bearing tellurides occur mainly within pyrite $\mathrm{H}_{1}$, together with inclusions of ore-stage sulfides (e.g., chalcopyrite, galena and sphalerite). Gold along healed pyrite fractures is found in both pyrite subtypes $\left(\mathrm{H}_{1}\right.$ and $\left.\mathrm{H}_{2}\right)$.

The textural association between native gold and pyrite $\left(\mathrm{H}_{1}\right)$, together with the positive correlation of gold and whole-rock sulfur concentrations $\left(r^{2}=0.47\right.$ in metasediments $)$, indicates that pyrite and gold mineralization are genetically related. Previous work (Helt et al., 2014) suggested that replacement of ferromagnesian silicates and iron oxides (including magnetite and ilmenite) by pyrite destabilized goldbisulfide complexes $\left(\mathrm{Au}(\mathrm{HS})_{2}^{-}\right)$in the mineralizing fluid and was responsible for the deposition of gold- 
431 bearing minerals at a temperature of $\sim 475^{\circ} \mathrm{C}$, under relatively oxidizing (just above the magnetite-

432 hematite buffer) conditions.

Textural and Compositional Characteristics of the Micas

\subsection{Nature and distribution of the micas}

Gold mineralization at Canadian Malartic is associated with widespread microcline-biotite \pm white mica potassic alteration that affected most lithotypes. In the proximal alteration zone, biotite generally forms small clusters of fine- to medium-grained crystals $(<0.5 \mathrm{~mm})$ and also occurs as biotite-quartz-carbonatespyrite stringers that develop interstitially between patches of microcline-albite \pm quartz replacement (Fig.6E-J). In metasedimentary rocks, proximal biotite has a pale yellow to light brown/green color (typically attributed to a high $\mathrm{Mg \#}$ and/or a high Fe oxidation state) and yellowish to greenish pleochroism (Fig.6E,H). White mica is generally absent in proximal metasedimentary rocks (see Fig.11); it is typically restricted to highly aluminous mudstone facies, where white mica occurs within and adjacent to biotite-quartz-carbonate-pyrite stringers as finely disseminated grains $(<0.02 \mathrm{~mm})$. In the quartz monzodiorite, white mica consists of unoriented laths $(<0.3 \mathrm{~mm})$ associated with biotite, quartz, carbonate minerals and pyrite, and as a partial replacement of feldspar phenocrysts.

Metasedimentary rocks that underwent distal alteration have a higher modal proportion of micas than

448 It commonly occurs within alteration envelopes of ore-stage v2 veinlets, and as elongated grains $(<1 \mathrm{~mm}$ 449 long) that collectively form braided stringers interstitial to detrital grains in the matrix (Fig.7E-J). Distal 450 white mica is finer-grained than the biotite $(<0.1 \mathrm{~mm})$, and consists of disseminated grains in the matrix. 451 Elongate prisms of biotite and white mica define a pseudo-foliation (Fig.7F-G) that resulted from their 452 preferential orientation orthogonal to stress during $\mathrm{D}_{2}$ deformation. Syn-deformation crystallization of 453 alteration minerals is also evident from biotite (together with quartz, microcline and carbonates) in pyrite pressure shadows that consistently extend parallel to the pseudo-foliation (Fig.7F-G, I-J).

The metamorphic grade in the Malartic district exceeded the biotite zone of the upper greenschist 457 constituents of the pelitic metamorphic assemblage. Two generations of metamorphic biotite have been 458 distinguished in the metasedimentary rocks beyond the ore shell (Fig.5B). The main metamorphic 459 foliation $\left(\mathrm{S}_{2}\right)$ is defined by the preferential alignment of biotite flakes (generally $>0.03 \mathrm{~mm}$ long) that are 
locally associated with white mica (developed preferentially in finer-grained metasedimentary layers), chlorite and sulfide minerals (ellipsoidal aggregates of pyrrhotite-pyrite-pentlandite; see Fig.5F). An earlier metamorphic foliation $\left(\mathrm{S}_{1}\right)$ is usually poorly preserved and is characterized by relict (corroded) crystals of biotite at a high angle to $S_{2}$ in quartzo-feldspathic microlithons. Both metamorphic fabrics are best identified in $F_{2}$ fold hinges (Fig.5D), whereas $S_{1}$ biotite has been rotated parallel to $S_{2}$ elsewhere $\left(F_{2}\right.$ fold limbs). The $S_{1}$ and $S_{2}$ biotite have comparable optical properties; they are orange to dark brown colored and display a strong pleochroism (Fig.5B). A late generation of retrograde chlorite occurs commonly as non-oriented flakes (cutting across the $\mathrm{S}_{2}$ foliation), as well as a partial replacement of biotite within and beyond the ore shell.

\subsection{Mica composition}

The major and minor element composition of biotite ( 79 samples; $n=821$; Table 1 ) and white mica (47 samples; $\mathrm{n}=485$, Table 2 ) was analyzed (electron microprobe) in the metasedimentary rocks along a $\sim 3.5$ $\mathrm{km}$ north-south cross-section $\left(\mathrm{P}_{2}\right)$ extending from the ore shell towards the Lac Fournière pluton (Fig.12A). The mica stoichiometry was calculated on the basis of $20 \mathrm{O}+4(\mathrm{OH}, \mathrm{F}, \mathrm{Cl})$ atoms according to the crystallochemical formula $\left[\mathrm{X}_{2} \mathrm{Y}_{4-6} \mathrm{Z}_{8} \mathrm{O}_{20}(\mathrm{OH}, \mathrm{F}, \mathrm{Cl})_{4}\right]$, with the site-specific occupancy determined following Pauling's rules (1929). Partition coefficients between coexisting biotite and white mica were calculated for a total of 47 metasedimentary rock samples and are presented in Appendix 1.

\subsubsection{Biotite chemistry}

The composition of biotite from hydrothermally-altered zones was distinguished from that of metamorphic biotite beyond the ore shell on the basis of the octahedral, tetrahedral and hydroxyl anion site chemistry. Figures 13 to 16 illustrate compositional changes as a function of distance from the Canadian Malartic deposit and emphasize the zonal distribution of the alteration, which is evident in the systematic decrease in biotite $\mathrm{Mg} \#\left[\right.$ molar $\left.\mathrm{Mg} /\left(\mathrm{Fe}_{\text {total }}+\mathrm{Mg}\right)\right]$ away from hydrothermal fluid pathways (Figs.11 and 14A). Biotite is phlogopitic in composition within the proximal alteration zone (biotite $\mathrm{Mg}$ end-member; $0.72<\mathrm{Mg \#}<0.92)$ and is also enriched in $\mathrm{Mg}$ relative to $\mathrm{Fe}$ in the distal alteration zone $(0.52<\mathrm{Mg} \#<0.72)$. By contrast, metamorphic biotite consistently has intermediate $\mathrm{Mg \#}$ compositions $(0.45<\mathrm{Mg} \#<0.58)$, which display a weak increasing trend southwards. There is no correlation between the

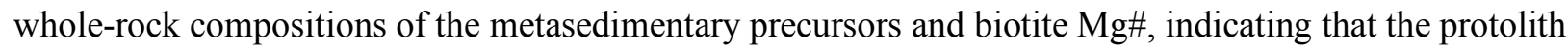
did not exercise a control on the biotite chemistry. Microprobe analyses of coexisting metamorphic $\mathrm{S}_{1}$ and 
$\mathrm{S}_{2}$ biotite yield similar compositions (Table 1), which suggest that $\mathrm{S}_{1}$ biotite likely re-equilibrated during the $\mathrm{M}_{2}$ metamorphic event.

The mechanisms of element incorporation in biotite were evaluated by determining ratios of cations

492 (or sum of cations) involved in potential substitution reactions from binary plots. A linear distribution and near-unity negative slope of $-0.79\left(\mathrm{r}^{2}=0.97\right)$ for Fe versus Mg (Fig. 14B) indicates that variations in the

494 biotite $\mathrm{Mg} \#$ in the octahedral site are accounted for mainly by the substitution $\mathrm{Fe}^{2+} \Leftrightarrow \mathrm{Mg}$ (annite-

495 phlogopite solid solution). The small deviation from unity suggests the presence of $\mathrm{Fe}^{3+}$ in the crystal structure and/or participation of other substitution reactions, likely involving $\mathrm{Ti}^{4+}$, in determining the composition of the octahedral site. Our observations show that the Mg-rich biotite tends to incorporate a smaller proportion of Ti (Table 1), consistent with the observations of Henry et al. (2005).

Increasing proximity to hydrothermal fluid pathways in altered rocks is manifested by a gradual decrease in the total $\mathrm{Al}$ concentration of the biotite, coincident with increases in $\mathrm{Si}$ and $\mathrm{Fe}+\mathrm{Mg}$ contents

501 (Fig.13A-D). Significantly, Al concentrations in biotite of the proximal alteration zone range between 5022.28 and $3.05 \mathrm{apfu}(\mathrm{mean}=2.69 \mathrm{apfu})$, and for the distal alteration between 2.70 and $3.09 \mathrm{apfu}(\mathrm{mean}=2.94$ $503 a p f u$ ). Metamorphic biotite beyond the ore shell is characterized by consistently higher Al concentrations, 504 ranging from 3.08 to $3.48 \mathrm{apfu}$ (mean=3.26 apfu). In addition, metamorphic biotite displays a progressive 505 increase in the proportion of $\mathrm{Al}$ with increasing distance southwards, which is matched by a 506 corresponding decrease in $\mathrm{Si}$ (tetrahedrally-coordinated) and $\mathrm{Fe}+\mathrm{Mg}$ (octahedrally-coordinated) contents.

507 The overall charge associated with the substitution of $\mathrm{Al}^{\mathrm{IV}}$ for tetravalent $\mathrm{Si}$ was balanced through a 508 coupled Tschermak exchange of $\mathrm{Al}^{\mathrm{VI}}$ for divalent $\mathrm{Fe}$ and $\mathrm{Mg}$ cations in the octahedral site: $\left[\left(\mathrm{Fe}^{2+}, \mathrm{Mg}^{2+}\right)^{\mathrm{VI}}\right.$ $\left.509+\left(\mathrm{Si}^{4+}\right)^{\mathrm{IV}} \Leftrightarrow\left(\mathrm{Al}^{3+}\right)^{\mathrm{VI}}+\left(\mathrm{Al}^{3+}\right)^{\mathrm{IV}}\right]$, as shown by a plot of $\mathrm{Fe}+\mathrm{Mg}+\mathrm{Si}$ vs. total $\mathrm{Al}$ (slope of $-0.97 ; \mathrm{r}^{2}=0.90$;

510 Fig.14D). This plot illustrates the decrease in the extent of the $\mathrm{Si}_{1}(\mathrm{Fe}, \mathrm{Mg})_{1} \mathrm{Al}^{\mathrm{IV}}{ }_{-1} \mathrm{Al}^{\mathrm{VI}}{ }_{-1}$ Tschermak

511 exchange in biotite towards more aluminous compositions (in the direction of the siderophyllite-eastonite 512 join) with increasing distance southwards (i.e., towards higher metamorphic grade; Fig. 14C).

513 Compositional variation in the biotite interlayer site consists of a general decrease in the K content 514 (from 1.97 to $1.70 \mathrm{apfu}$ ), coincident with a progressive increase in Na content (from 0.00 to 0.09 apfu) 515 along the north-south $\mathrm{P}_{2}$ section southwards (Fig.13E-F). The biotite anion site underwent significant 516 substitution of fluorine $\left(\mathrm{F}^{-}\right)$for hydroxyl $\left(\mathrm{OH}^{-}\right)$, which increased with increasing proximity to 517 hydrothermal fluid pathways (Fig.15A; Table 1); generally, chlorine (Cl-) concentrations are below the 
lower limit of detection. The fluorine concentration of biotite outside the ore shell is generally low (0.05$0.20 \mathrm{apfu}$; mean $=0.09 \mathrm{apfu})$ and is nearly three times higher in the distal $(0.12-0.77 \mathrm{apfu}$; mean $=0.25$ $a p f u)$, and proximal (0.04-0.89 apfu; mean=0.26 apfu) alteration zones. Fluorine incorporation into the

521 hydroxyl site has been demonstrated experimentally and thermodynamically to be dependent on the octahedral site composition, halogen activity and temperature (Zhu and Sverjensky, 1992; Munoz, 1992). At Canadian Malartic, the fluorine content of biotite covaries with Mg\# (Fig.15D), in good agreement with the crystal-chemical Fe-F avoidance principle (Munoz, 1984).

\subsubsection{White mica chemistry}

The zonal distribution of alteration features at Canadian Malartic is associated with systematic variations in white mica composition (Fig.11). In altered metasedimentary rocks, white mica is characteristically phengitic in composition $(\mathrm{Fe}+\mathrm{Mg}>0.6$ apfu $)$, as indicated by higher $\mathrm{Si}$ and $\mathrm{Fe}+\mathrm{Mg}$ contents, as well as lower Al concentrations than metamorphic white mica (Fig.17; Table 2). A trend toward muscovite end-member compositions is indicated by a progressive increase in total $\mathrm{Al}$ concentration and decreases in $\mathrm{Si}$ and $(\mathrm{Fe}+\mathrm{Mg})$ contents southwards (Fig.17A-D). These relationships are

532 largely controlled by a Tschermak exchange reaction (Fig.18A), as demonstrated by the correlation $\left(\mathrm{r}^{2}\right.$ $533=0.99)$ and near-unity negative slope $(\mathrm{m}=-0.99)$ for $(\mathrm{Fe}+\mathrm{Mg}+\mathrm{Si}) v s$. total $\mathrm{Al}(\mathrm{Fig} .18 \mathrm{~B})$. However,

534 substitution mechanisms involving $\mathrm{Fe}^{3+}$ (e.g., ferrimuscovite substitution, $\left.\left[\left(\mathrm{Fe}^{3+}\right)^{\mathrm{VI}} \Leftrightarrow\left(\mathrm{Al}^{3+}\right)^{\mathrm{VI}}\right]\right)$ may have 535 played a role in controlling the white mica composition, as evidenced by the deviation from the ideal 536 Tschermak substitution line on a plot of $(\mathrm{Fe}+\mathrm{Mg}) v s$. total $\mathrm{Al}$ (slope of $-0.64, \mathrm{r}^{2}=0.94$; ideal slope of 537 0.5). Deviations from ideality might also be related to the contribution of Ti, which is more abundant in 538 white mica from the altered zones (0.05-0.12 apfu) than from the unaltered rocks (0.03-0.06 apfu). In 539 contrast to biotite, hydrothermal and metamorphic white mica cannot be distinguished on the basis of 540 their $\mathrm{Mg}$ numbers and there is no evidence of systematic Fe-Mg substitution associated with alteration (Fe $541 v s$. Mg display a positive relationship with a $\mathrm{r}^{2}$ value of 0.41 ).

542 The white mica interlayer site composition varies considerably $(\mathrm{K}=1.54-1.92, \mathrm{Na}=0.03-0.30$ apfu $)$ 543 with increasing distance southwards from the deposit (Table 1). There is a general decrease in the white 544 mica K content (Fig.17E-F), coincident with increases in $\mathrm{Na}$ and $\mathrm{Ba}$ (towards a paragonitic muscovite 545 composition). A substitution of $\mathrm{Na}$ and $\mathrm{Ba}$ for $\mathrm{K}$ is inferred from the correlation between $(\mathrm{Na}+\mathrm{Ba})$ and $\mathrm{K}$ 
546 (slope of $\left.-0.72, \mathrm{r}^{2}=0.82\right)$. The halogen content of white mica $(\mathrm{F}, \mathrm{Cl})$ is generally below the lower detection

547 limit; F was detectable in only 47 out of 567 analytical points, reaching a maximum of 0.14 apfu.

\section{Whole-Rock Geochemistry}

The distribution and extent of alteration-related mass changes document a lithogeochemical zonation that reflects changes in the fluid-rock ratio and the strength of gold mineralization (Helt et al; 2014). Mass change calculations (e.g., MacLean and Barrett, 1993), involving a comparison of the average composition of altered $(n=576)$ and least-altered metasedimentary rocks $(n=20)$, show that hydrothermal alteration was associated with enrichments in $\mathrm{K}_{2} \mathrm{O}, \mathrm{Na}_{2} \mathrm{O}, \mathrm{S}, \mathrm{C}$ and loss on ignition (Fig. 12B-C; Gaillard et al., 2015). This observation is consistent with the mineralogical nature of the alteration assemblage (microcline-albite-biotite \pm white mica-carbonates-pyrite). Distal and proximal alteration in metasedimentary rocks are characterized by significant gains in potassium (average $+66 \%$ and $+161 \%$ compared to least altered equivalents, respectively), which define a lithogeochemical zoning with respect to gold mineralization (Fig.12C). Progressive sulfidation around hydrothermal pathways was manifested by increasing mass gains in sulfur from unaltered Pontiac metasedimentary rocks through distal (average 0.75 wt. $\% \mathrm{~S}$, corresponding to $+384 \%$ compared to least altered equivalents) to proximal (average 2.69 wt. $\%$ S; i.e. $+1740 \%$ ) alteration zones (Fig.12B). Most significantly, trace elements associated with hostrock sulfidation (Ag-Te-W-Bi-Mo-As-Sb-Pb) underwent steadily increasing mass gains towards gold mineralization, reaching concentrations several orders of magnitude higher in altered metasedimentary rocks than the least altered equivalents (Gaillard et al., 2015). In general, ratios involving Fe, $\mathrm{Mg}$, Ti and $\mathrm{Al}$ are essentially constant, suggesting that these elements were relatively immobile during alteration.

A subset of 79 samples collected along the $\mathrm{P}_{2}$ north-south cross-section (Fig.2) was used to assess variations in the whole-rock fluorine content in hydrothermally altered metasedimentary rocks (Fig.15B). Unaltered metasedimentary rocks are characterized by low fluorine contents, ranging between 300 and $750 \mathrm{ppm}($ mean=485 ppm; $\mathrm{n}=34)$. Distal alteration in the metasedimentary rocks was associated with

572 lowest whole-rock and biotite fluorine contents are from the proximal alteration zone in drillhole DDH-

5731578 and correspond to strongly brecciated samples, suggesting that halogen devolatilization might have

574 been facilitated by late fluid circulation in a permeable medium. 


\subsection{Physico-chemical controls on biotite composition}

Steep gradients of sulfidation $\left(\sum a \mathrm{~S}\right)$ and oxidation $\left(f \mathrm{O}_{2}\right)$ are indicated by systematic variations in the sulfide-oxide mineral assemblage outwards from the hydrothermal fluid pathways (Section 4.3; Figs.9 and 11). These variations coincide spatially with changes in the composition of ferromagnesian silicates (Figs.11, 13-14). A strong positive correlation between the biotite Mg\# and the whole-rock sulfur content (Fig.16) suggests that increases in $\sum a \mathrm{~S}-\mathrm{fO}_{2}$ conditions affected biotite composition. Similar trends of magnesium enrichment in (Fe-Mg)-silicates have been documented for the sulfidation-oxidation haloes of many ore deposit types, including Cu- (Hezarkhani et al, 1999; Boomeri et al., 2009; Wilkinson et al., 2015) and Mo- (Gunow et al., 1980) porphyry deposits, Archean Au deposits (Heiligmann et al, 2008; Bath et al., 2013), as well as metamorphosed VMS (Nesbitt, 1986a,b; Zaleski et al., 1991; Spry, 2000) and carbonate-hosted $\mathrm{Pb}-\mathrm{Zn}$ deposits (Chabu, 1995).

\subsubsection{Thermodynamic modelling}

Thermodynamic modelling of silicate-oxide-sulfide equilibria was conducted to assess the effects of varying $\sum a \mathrm{~S}-f \mathrm{O}_{2}$ on the stability and composition of biotite in altered rocks of the Canadian Malartic deposit. Phase relationships among the main alteration minerals and aqueous sulfur species were evaluated for the system Fe-O-H-S through a series of $\mathrm{fO}_{2}$-pH binary diagrams (Fig.19) constructed for the inferred ore-forming conditions $\left(475^{\circ} \mathrm{C}\right.$ and $3 \mathrm{kbars}$; Helt et al., 2014). The HCh Unitherm software (Shvarov and Bastrakov, 1999) was used to derive thermodynamic data (log K) for reactions that define predominance fields and phase boundaries (Johnson et al., 1992; Robie and Hemingway, 1995; Shock et al., 1997; Holland and Powell, 1998). Given the absence of fluid inclusion constraints, the activity of potassium $\left(a \mathrm{~K}^{+}\right)$was set at 0.08 molal, as calculated by Helt et al. (2014) from the equilibration of a low salinity fluid $(\mathrm{NaCl}=6 \mathrm{wt} . \%)$ with microcline and albite. The $a-x$ relationships of biotite $\left(a \begin{array}{l}\text { biotite } \\ \text { annite }\end{array}\right)$ and white mica ( $\left.a \begin{array}{c}\text { white mica } \\ \text { muscovite }\end{array}\right)$ solid solutions were calculated from the thermodynamic properties of the endmembers using ideal on-site mixing models (Powell et al., 1998). The activity of the annite component in biotite was determined for characteristic compositions of metamorphic biotite in the metasedimentary rocks outside the ore shell $\left(\mathrm{Mg} \#=0.57 ; \mathrm{Al}^{\mathrm{VI}}=0.56\right.$ apfu $)$, and of biotite in the distal $\left(\mathrm{Mg} \#=0.68 ; \mathrm{Al}^{\mathrm{VI}}=0.46\right.$ apfu $)$ and proximal $\left(\mathrm{Mg} \#=0.81 ; \mathrm{Al}^{\mathrm{VI}}=0.35\right.$ apfu $)$ hydrothermal alteration zones. Consideration of the $\mathrm{Mg} \#$ 
603

604

605

606

607

608

609

610

$611\left(\log a_{\text {annite }}^{\text {biotite }}=-1.62\right.$ and -2.25 , respectively $)$ demonstrates that the biotite activity calculations were 612 influenced mainly by variations in the $\mathrm{Mg} \#$ of the biotite.

and $\mathrm{Al}^{\mathrm{VI}}$ compositional variables in the biotite activity calculations made it possible to account accurately for both the Fe-Mg and Tschermak substitutions (see Fig.14). However, the two parameters make an antithetic contribution to the calculated activity of annite in the biotite solid solution. Increasing proximity to hydrothermal fluid pathways was indeed associated with biotite compositional trends away from the annite pole towards the phlogopite-eastonite join (Fe-Mg substitution; Fig. 14A) as well as towards the annite pole away from the siderophyllite-eastonite join (Tschermak substitution; Fig.14C). The decrease in the calculated activity of the annite end-member with increasing proximity to hydrothermal corridors from metamorphic biotite outside the ore shell $\left(\log a_{\text {annite }}^{\text {biotite }}=-1.27\right)$ to distal and proximal biotite

\subsection{2. $\sum \mathrm{aS}-\mathrm{fO}_{2}$ controls on biotite composition}

A series of $f \mathrm{O}_{2}$-pH diagrams (Fig.19) illustrates the evolution of silicate-oxide-sulfide equilibria for increasing total activity of aqueous sulfur species $\left(\sum a \mathrm{~S}=0.1 ; 0.3\right.$; and $\left.1 \mathrm{~m}\right)$, covering the range of $\sum a \mathrm{~S}$ values commonly estimated for intrusion-related and orogenic-type gold mineralization in subamphibolite facies systems (e.g., Mikucki, 1998). At a low total activity of sulfur species $\left(\sum a \mathrm{~S}=0.1 \mathrm{~m}\right)$, the stability of ilmenite and the replacement of pyrite by pyrrhotite in metasedimentary rocks outside the ore shell constrain the metamorphic fluids to relatively reducing apparent conditions $\left(\log f \mathrm{O}_{2}\right.$ below -26 , i.e., $\sim 3.5 \log f \mathrm{O}_{2}$ units below the magnetite-hematite buffer). The occurrence of intermediate $\mathrm{Mg} \#$ biotite and the common association with white mica in the metamorphic assemblage suggest weakly acidic conditions ( $\mathrm{pH} \sim 4$, with neutral $\mathrm{pH}$ at $475^{\circ} \mathrm{C}$ and $3 \mathrm{kbars}$ calculated to be $\sim 4.8$ ) for metamorphism beyond the ore shell (purple star in Fig.19A). In the hydrothermal alteration assemblage, the presence of high-Mg\# biotite, microcline, phengitic white mica (in the distal assemblage), pyrite and rutile, together with the absence of pyrrhotite indicate that oxygen fugacity was higher during ore formation (constrained to $\log f \mathrm{O}_{2} \sim-21$ at $\sum a \mathrm{~S}=0.1 \mathrm{~m}$, i.e., $1.5 \log f \mathrm{O}_{2}$ units above the magnetite-hematite buffer). In altered quartz monzodiorite, replacement of magnetite by hematite and the occurrence of sulfates support a relatively elevated oxidation state for the mineralizing fluid, close to the $\mathrm{H}_{2} \mathrm{~S}-\mathrm{HSO}_{4}{ }^{-}$predominance field boundary. Stability relationships among K-silicates in hydrothermally-altered metasediments, including intense microclinization (Fig.8) and paucity or absence of white mica (Figs.6 and 11) in the proximal alteration zone, suggest that $\mathrm{pH}$ evolved to higher values $(\geq 5.2)$ upon interaction with a mildly alkaline 
632

633

634

635

636

637

638

639

640

641

642

643

644

645

646

647

648

649

650

ore-forming fluid, although increasing values of $a \mathrm{~K}^{+}$could also account for the expansion of the stability field of microcline at the expense of that of white mica at constant $\mathrm{pH}$, as will be discussed in the following section (see 7.2.1).

An increase in the activity of sulfur species associated with hydrothermal alteration results in the expansion of the pyrite stability field at the expense of pyrrhotite, hematite and magnetite (Fig.19B-C). Most importantly, higher $\sum a \mathrm{~S}$ values cause a shift in the equilibria of sulfidation reactions that involve Fe-sulfides and silicates (biotite, white mica and microcline). As such, progressive sulfidation favors the stability of pyrite (together with microcline and/or white mica) over biotite as the dominant Fe-bearing mineral phase at the conditions of gold mineralization. In proximal alteration zones, these reactions are manifested by textures documenting the replacement of biotite by microcline and by an increase in the modal proportion of microcline and pyrite at the expense of biotite and white mica (Fig.6E-J, Fig.8). Iron sequestration by pyrite, in turn, affects the stability of (Fe-Mg)-silicates and promotes the stability of more magnesian biotite compositions (Heiligmann et al., 2008). At $\sum a \mathrm{~S}=0.3 \mathrm{~m}$, intermediate $\mathrm{Mg \#}$ metamorphic biotite would not be stable at the inferred ore-forming $f \mathrm{O}_{2}-\mathrm{pH}$ conditions (green star in Fig.19B), and biotite stability would be restricted to magnesian compositions typical of distal and proximal alteration zones. At $\sum a \mathrm{~S}=1 \mathrm{~m}$, the stability of the annite end-member in biotite is further reduced at the expense of sulfides, and distal alteration zone biotite is superseded by proximal phlogopitic biotite in the ore assemblage, which would be the only stable biotite at these specific conditions (orange star in Fig.19C).

\subsection{Physico-chemical controls on white mica composition}

The investigation of the major element chemistry of white mica (EPMA) and its spectral characteristics (Lypaczewski et al., in prep.) revealed systematic variations from near end-member muscovite in the metasedimentary rocks beyond the ore shell to more phengitic compositions in hydrothermally-altered rocks (Figs.11, 17-18). In addition, the mineralogical zoning from proximal potassic (microcline-phlogopite-dominated) to distal potassic-sericitic (high-Mg\# biotite- microclinephengite) alteration zones indicates subtle changes in the stability relationships among K-bearing hydrothermal alteration minerals. These variations are interpreted to reflect changes in physico-chemical parameters, and were used to map the spatial distribution and intensity of fluid-rock interactions, and to define activity gradients towards hydrothermal fluid pathways (Halley et al., 2015). Calculations of 
equilibria involving microcline, biotite and white mica were achieved by balancing individual reactions using $\mathrm{K}^{+}, \mathrm{Fe}^{2+}$ and $\mathrm{H}^{+}$, so that phase relationships within this system could be adequately described as a

663 function of $a \mathrm{Fe}^{2+} / a^{2} \mathrm{H}^{+}$and $a \mathrm{~K}^{+} / a \mathrm{H}^{+}$activity ratios (Seedorff and Einaudi, 2004). The relative effects of

664 these parameters on the composition and stability of K-silicates were evaluated by computing phase relationships in a subset of the $\mathrm{K}-\mathrm{Fe}-\mathrm{O}-\mathrm{H}$ system using the Unitherm $\mathrm{HcH}$ software, following the same methodology described in section 7.1.1.

The white mica compositional trends associated with increasing proximity to hydrothermal fluid pathways (Fig.17) were shown to be controlled essentially by a Tschermak exchange reaction (Fig.18). In contrast to biotite, the activity of the muscovite component in white mica ( $a$ white mica muscovite $)$ was therefore determined entirely by the $\mathrm{Al}^{\mathrm{VI}}$ content of the octahedral site (Powell et al., 1998). As discussed in the previous section (see 7.1.1), the magnitude of the Fe-Mg substitution in distal and proximal alteration biotite (increase in $\mathrm{Mg} \#$ towards hydrothermal fluid pathways) essentially masked the effects of the Tschermak exchange in the biotite activity calculations, preventing any assessment of the physicochemical controls on the Tschermak substitution. Therefore, the geochemical effects on the Tschermak exchange in white mica, modelled in this section, could serve as a proxy for understanding the controls on analogous trends in biotite (e.g., compositional variations towards the annite-phlogopite join).

\subsubsection{Effects of $\mathrm{K}^{+}, \mathrm{Fe}^{2+}$ and $\mathrm{H}^{+}$activities on white mica composition}

Physico-chemical effects on the composition of white mica were investigated through the construction of a binary diagram illustrating phase equilibria among K-silicates as a function of $a \mathrm{Fe}^{2+} / a^{2} \mathrm{H}^{+}$and $a \mathrm{~K}^{+} / a \mathrm{H}^{+}$activity ratios (Fig.20). Equilibrium textures between metamorphic biotite and white mica of muscovitic composition ( $\log a$ white mica $=-0.11)$, the occurrence of ilmenite, and the absence of microcline in the metasedimentary rocks beyond the ore shell constrained geochemical conditions to relatively low values of $a \mathrm{~K}^{+} / a \mathrm{H}^{+}$, with $a \mathrm{Fe}^{2+} / a^{2} \mathrm{H}^{+}$values buffered along the univariant boundary between the muscovite and biotite stability fields (purple star in Fig.20). The presence of microcline in the distal alteration assemblage is consistent with an evolution towards higher values of $a \mathrm{~K}^{+} / a \mathrm{H}^{+}$, concurrent with a decrease in $a \mathrm{Fe}^{2+} / a^{2} \mathrm{H}^{+}$in the direction of the invariant point defined by the coexistence of microcline, phengite $(\log a \underset{\text { muscovite }}{\text { white }}=-0.25)$ and high-Mg\# biotite (green star in Fig.20). The absence or paucity of white mica from the proximal alteration assemblage in the metasedimentary rocks is further evidence for $a \mathrm{~K}^{+} / a \mathrm{H}^{+}$ conditions having increased towards hydrothermal fluid pathways with decreasing values of $a \mathrm{Fe}^{2+} / a^{2} \mathrm{H}^{+}$, 
which were buffered along the univariant boundary between microcline and phlogopitic biotite (orange star in Fig.20).

In the modelled system, the compositional trend towards a more phengitic composition with increasing proximity to hydrothermal corridors was determined entirely by the $a \mathrm{~K}^{+} / a \mathrm{H}^{+}$ratio, and is consistent with an increase in $a \mathrm{~K}^{+}$and/or $\mathrm{pH}$ (Fig.20). The overall decreasing trend in $a \mathrm{Fe}^{2+} / a^{2} \mathrm{H}^{+}$towards hydrothermal

695 fluid pathways was mainly due to sequestration of $\mathrm{Fe}^{2+}$ by pyrite. The contribution of the Tschermak

696 substitution in biotite, however, is manifested by an increase in the activity of the annite end-member with

697 increasing proximity to hydrothermal corridors, which effectively causes less aluminous biotite to be

698 stabilized at the expense of microcline at higher $\mathrm{pH}$ and/or $a \mathrm{Fe}^{2+}$ (higher $a \mathrm{Fe}^{2+} / a^{2} \mathrm{H}^{+}$). The spatial

699 variation in the composition of white mica and biotite, the decline in the intensity of microcline alteration

700 (Cf. Fig.8) and the decrease in calculated potassium mass gains (Fig.12C) are all consistent with

701 progressive rock-buffering (decrease in the fluid-rock ratio) of a mildly alkaline, potassium-rich ore-

702 forming fluid away from the hydrothermal corridors (Oliver et al., 2004; Cleverley and Oliver, 2005). The

703 transition from proximal potassic to distal potassic-sericitic alteration is interpreted to record the passage

704 of a metasomatic front along the fluid diffusion path (Korzhinskii, 1968), as white mica stabilized in

705 response to gradual equilibration of the fluid with the host-rock (progressive decrease in $a \mathrm{~K}^{+}$and/or $\mathrm{pH}$

706 away from the hydrothermal centers).

\section{Thermodynamic Modelling of Metamorphism}

708 The well-constrained positive gradient of metamorphic pressure-temperature (P-T) conditions southwards of the Canadian Malartic deposit (Piette-Lauzière, 2017) was used as a framework in which to investigate the district-scale effects of metamorphism on the composition of biotite and white mica.

711 Multicomponent phase diagrams (pseudosections) were calculated for two representative samples of 712 Pontiac metasedimentary rocks in order to model the composition of mica solid solutions under varying 713 P-T conditions.

\subsection{Mineral equilibria calculations}

Metamorphic phase diagrams were computed for P-T conditions ranging from 425 to $675^{\circ} \mathrm{C}$ and 2 to

71610 kbar using the Perple_X software (Connolly and Petrini, 2002; Connolly, 2005) in conjunction with a

717 recently updated version (ds6.2) of the internally consistent thermodynamic dataset of Holland and 
$719 \mathrm{SiO}_{2}-\mathrm{H}_{2} \mathrm{O}-\mathrm{TiO}_{2}-\mathrm{Fe}_{2} \mathrm{O}_{3}(\mathrm{MnNCKFMASHTO})$, which enabled integration of a comprehensive range of 720 mineral solutions for metasedimentary rock assemblages. Activity-composition $(a-x)$ thermodynamic 721 models used for the calculations included those for biotite, white mica, chlorite, garnet, orthopyroxene, staurolite, cordierite and melt from White et al. (2014a,b), epidote from Holland and Powell (2011),

723 ilmenite from White et al. (2000) and feldspar from Fuhrman and Lindsley (1988). As a first approximation, the system was considered to be $\mathrm{CO}_{2}$-free and saturated with respect to $\mathrm{H}_{2} \mathrm{O}$. Bulk compositions used to constrain the calculations were determined from whole-rock XRF analysis. Ferric iron $\left(\mathrm{Fe}^{3+}\right)$ was fixed to $\mathrm{Fe}^{3+} / \mathrm{Fe}_{\text {total }}=0.05$ based on the average value for metasedimentary rock from drillhole CD08-D6 (as determined by FeO titration). The latter reflects the overall reducing nature of the protolith, although erratic occurrences of magnetite in the pelitic assemblage suggest local variations in the $\mathrm{Fe}^{3+}$ content of the metasedimentary rocks.

\subsection{Petrography and mineral chemistry}

Calculations of metamorphic phase equilibria (P-T pseudosections) were constrained by bulk-rock compositions of two samples of non-altered, non-mineralized Pontiac Group metasedimentary rocks (Figs.21-22). These samples span the range from greywacke (sample K389136) to mudstone (K389232), and display distinct metamorphic assemblages. They are located 1.5 and 2.5 kilometers south of the southern edge of the Canadian Malartic open-pit, respectively (Fig.2).

Sample K389136 displays a well-developed $\mathrm{S}_{2}$ fabric defined by the alignment of elongated biotitechlorite aggregates in a matrix of poorly-sorted medium-grained quartz and feldspar (Fig.5F). The metamorphic assemblage includes garnet, and delineates the garnet-in isograd along the $\mathrm{P}_{2}$ section southwards (Fig.12A). The garnet occurs as porphyroblastic dodecahedrons ( $\sim 0.2 \mathrm{~mm}$ in diameter), and together with biotite, chlorite, plagioclase, quartz and ilmenite, corresponds to the peak metamorphic assemblage. It displays a very subtle concentric zoning (Piette-Lauzière, 2017), with a narrow range of $\mathrm{Alm}_{63 \rightarrow 62}, \operatorname{Prp}_{9 \rightarrow 8}, \mathrm{Grs}_{5}, \mathrm{Sps}_{22 \rightarrow 24}$ (from core to rim). The biotite has the following compositional characteristics: $\mathrm{Mg \#}=0.53, \mathrm{Al}_{\mathrm{tot}}=3.41 \mathrm{apf} u$ and $\mathrm{Si}=5.42 \mathrm{apf} u$ and the chlorite, which is in textural equilibrium with the biotite, classifies compositionally as ferroan clinochlore (ripidolite) with $\mathrm{Mg} \#=0.57$, $\mathrm{Al}_{\text {tot }}=5.58 \mathrm{apf} u$ and $\mathrm{Si}=5.26 \mathrm{apfu}$. The plagioclase has an average composition of $\mathrm{An}_{29}$ (oligoclase), which varies little at the thin section scale, suggesting complete re-equilibration. Retrograde features are 
restricted to the rare partial replacement of ilmenite by fine-grained rutile and titanite. Sulfides are present in minor proportions and consist of aggregates of pyrrhotite \pm (chalcopyrite-pentlandite) that are aligned parallel to the $\mathrm{S}_{2}$ foliation.

Sample K389232 is dominated by a higher-grade metamorphic assemblage that includes staurolite, garnet, white mica, biotite, chlorite, plagioclase, quartz and ilmenite (Fig.5E). The main fabric $\left(\mathrm{S}_{2}\right)$ consists of a zonal schistosity defined by the preferential orientation of phyllosilicates. The quartz was recrystallized and, together with the plagioclase $\left(\mathrm{An}_{32}\right)$, forms an equigranular mosaic of interlocked crystals with characteristic $120^{\circ}$ triple junctions (granoblastic texture). Biotite in the matrix has the compositional characteristics, $\mathrm{Mg \#}=0.54, \mathrm{Al}_{\mathrm{tot}}=3.48$ apfu and $\mathrm{Si}=5.36$ apfu; the white mica is muscovitic, with a substantial paragonite component $(\mathrm{Na}=0.30$ apfu $), \mathrm{Al}_{\mathrm{tot}=5.64}$ apfu and $\mathrm{Si}=6.13$ apfu. The garnet is subhedral in habit and displays weak core to rim zoning, with a compositional range of Alm $67 \rightarrow 69$, $\operatorname{Prp}_{13 \rightarrow 12}, \mathrm{Grs}_{6 \rightarrow 5}, \mathrm{Sps}_{13}$. Staurolite (Mg\#=0.19) occurs as homogeneously distributed poikiloblasts up to 5 $\mathrm{mm}$ in diameter, which consistently record a syn-kinematic rotation (Fig.5E). They contain trails of quartz, biotite, white mica and ilmenite inclusions that define an internal foliation, continuous with the main $\mathrm{S}_{2}$ fabric. Chlorite occurs as a replacement of staurolite and as rare rosettes that crosscut the main foliation. The chlorite is compositionally homogeneous and consists of ferroan clinochlore (ripidolite),

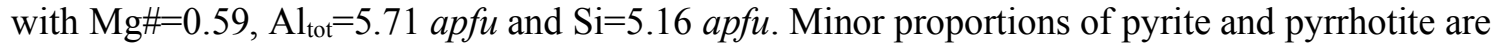
distributed parallel to the main $\mathrm{S}_{2}$ fabric.

\subsection{Pseudosection modelling}

The stability relationships among metamorphic minerals in samples K389136 and K389232 were established through the construction of the P-T pseudosections presented in Figures 21 and 22, respectively. The peak metamorphic conditions for mudstone sample K389136 (garnet-biotite-chloriteplagioclase-quartz-ilmenite assemblage) are reproduced in the pseudosection at lower amphibolite facies conditions, from 565 to $585^{\circ} \mathrm{C}$ and 2.8 to $5.0 \mathrm{kbar}$ (Fig.21A). Field evidence indicates a general lack of cordierite in the metasedimentary rocks south of the deposit; considering the variability due to protolith composition, it is therefore likely that peak metamorphic conditions were in the higher pressure range, away from the cordierite-in iso-reaction line. These conditions were further constrained by calculating compositional isopleths for the garnet core composition $\left(\mathrm{X}_{\mathrm{Ca}}=0.05\right.$ and $\left.\mathrm{Mg} \#=0.12\right)$, the intersection of which indicates metamorphism reached $\sim 570^{\circ} \mathrm{C}, 4.4-5.0 \mathrm{kbar}$. The calculated stability field of the peak 
assemblage closely coincides with the garnet-in iso-reaction line, in good agreement with the spatial proximity of sample K389136 relative to the garnet-in isograd (Fig.2). The modelled compositions of plagioclase $\left(\mathrm{An}_{29}\right)$ and chlorite $\left(\mathrm{Mg} \#=0.57, \mathrm{Al}_{\text {tot }}=5.61\right.$ apf $u$ and $\mathrm{Si}=5.04$ apfu $)$ at the inferred peak conditions match almost perfectly the measured compositions. The textural evidence of replacement of ilmenite by rutile is consistent with a retrograde evolution of conditions through the stability field of rutile at a temperature below $500{ }^{\circ} \mathrm{C}$.

The peak metamorphic assemblage of greywacke sample K389232 consists of staurolite-garnet-white mica-biotite-chlorite-plagioclase-quartz-ilmenite, which is reproduced in the pseudosection at midamphibolite facies conditions, corresponding to a P-T range from 575 to $615^{\circ} \mathrm{C}$ and 5 to $9 \mathrm{kbar}$ (Fig.22A). These constraints were further refined by calculating compositional isopleths for garnet core composition

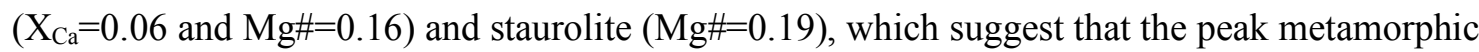
conditions reached $\sim 585^{\circ} \mathrm{C}, 5.2-6.4 \mathrm{kbar}$. This is consistent with the close spatial proximity of sample K389232 to the staurolite-in isograd line (Fig.2). The compositions of plagioclase $\left(\mathrm{An}_{32}\right)$ and chlorite $\left(\mathrm{Mg} \#=0.61, \mathrm{Al}_{\mathrm{tot}}=5.44\right.$ apf $u$ and $\left.\mathrm{Si}=5.13 \mathrm{apf} u\right)$ modelled for the sample at the above metamorphic conditions closely match those of plagioclase and chlorite as determined from electron microprobe analyses. Curved chlorite aggregates within rotated staurolite strain shadows suggests that shearing (interpreted as late $\mathrm{D}_{2}$ ) took place during the retrograde path, immediately after peak metamorphism (in the field of chlorite stability). The topology of the muscovite-out iso-reaction lines in samples K389136 (Fig.21A) and K389232 (Fig.22A) underlines the compositional controls of the sedimentary protolith composition on the white mica occurrence. In particular, the field of muscovite stability expands to higher temperature in the more aluminous mudstone (e.g., K389232).

The constraints on peak metamorphic conditions provided by samples K389136 and K389232, together with the locations of the garnet and staurolite isograds (Piette-Lauzière, 2017) permitted an evaluation of the metamorphic field gradient in the Malartic district (Figs.21-22). The absence of high grade metamorphic phases (e.g., garnet or staurolite) prevented an accurate estimate of metamorphic conditions in the upper greenschist environment immediately adjacent to the deposit. The surficial gradient was therefore extrapolated on the basis of a gradual increase in P-T conditions southwards, from upper greenschist facies $\left(450-500^{\circ} \mathrm{C}\right)$ in the vicinity of the Cadillac Larder Lake Fault Zone to midamphibolite facies $\left(>550^{\circ} \mathrm{C}\right)$ a few kilometers to the south (sample K389232). This metamorphic 
805

806

evolution is typical of Barrovian metamorphism, which is characterized by an intermediate P/T gradient; the gradient for the Malartic district is estimated to be $\sim 30^{\circ} \mathrm{C} / \mathrm{km}$.

\subsection{Predictive evolution of metamorphic mica composition}

Variations in the equilibrium metamorphic assemblage, including modal abundance and mineral chemistry, are determined entirely by the temperature, pressure and bulk composition of the system. Systematic and progressive variations in the composition of biotite and white mica with increasing metamorphic grade have been documented for a number of metamorphic sequences in metasedimentary rocks and attributed to both continuous (e.g., Mg-Fe and Tschermak substitutions) and discontinuous, isograd-related reactions (Thompson, 1979; Guidotti, 1984; Miyashiro and Shido, 1985; Pattison, 1987; Dempster, 1992; Ikeda, 1998).

Compositional isopleths were computed for biotite and white mica in samples K389136 and K389232 to model the effects of increasing metamorphic pressure and temperature conditions (Figs.21-22). In both samples, the results of the compositional modelling for the estimated peak metamorphic conditions are in good agreement with the measured compositions of the micas. In sample K389136, the model composition of peak metamorphic biotite (Fig.21B-C) is predicted to have the characteristics (the analyzed values, in apfu, are indicated in the brackets): $\mathrm{Si}=5.28$ (5.42), $\mathrm{Al}_{\mathrm{tot}}=3.19$ (3.41), $\mathrm{Fe}+\mathrm{Mg}=5.36$

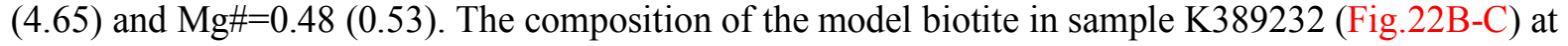
peak metamorphic conditions is estimated to be (in $a p f u$ ): $\mathrm{Si}=5.32$ (5.36), $\mathrm{Al}_{\text {tot }}=3.14$ (3.48), $\mathrm{Fe}+\mathrm{Mg}=5.41$

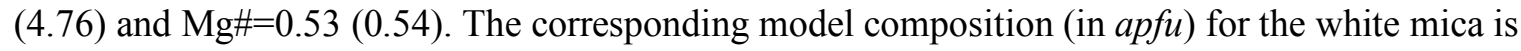

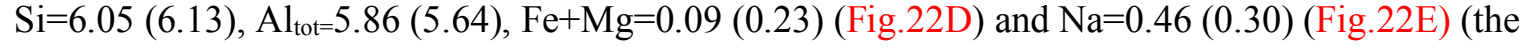
analyzed values are indicated in the brackets).

The thermodynamic modelling results (Figs.21-22) portray the main compositional variations observed in biotite and white mica outside the ore shell along the $\mathrm{P}_{2}$ section (Figs.13-14, 17-18), including the progression of the Tschermak substitution towards more aluminous compositions with increasing P-T conditions southwards. The latter was likely controlled by continuous prograde reactions between coexisting phyllosilicate phases, with biotite (and biotite+garnet at higher grade) progressively forming at the expense of white mica and/or chlorite (Cf. Miyashiro and Shido, 1985; Simpson et al., 2000). The Tschermak vector isopleth modelling in biotite (Figs.21B and 22B) and white mica (Figs.21D and 22D) shows comparable results in samples K389136 and K389232, which only diverge past the P-T 
834 limits of chlorite and muscovite stability. Minor discrepancies in the absolute estimate of the Tschermak

835 vector in biotite and white mica are accounted for mainly by differences between the calculated $\mathrm{Al}$ and

$836 \mathrm{Fe}+\mathrm{Mg}$ contents compared to the measured compositions. These inconsistencies coincide with disparities

837 between the observed and calculated chlorite and white mica modal abundances, which appear to be

838 slightly, but consistently overestimated in the output model (Piette-Lauzière, 2017). Given that the extent

839 of the Tschermak substitution in biotite and white mica is dictated entirely by exchange reactions with the

840 coexisting phyllosilicate phases, we expect the disparities in the modeled mineral modes to affect the

841 calculated magnitude of the cation exchange vectors. Such difference likely reflect inaccurate calibration

842 of the thermodynamic parameters used to constrain the phyllosilicate activity-composition models

843 (Powell et al., 2014; White et al., 2014a).

844 Isopleth modelling successfully depicts the progression of other important compositional gradients

845 observed in micas beyond the ore shell, including the steady to weakly increasing trend in biotite $\mathrm{Mg \#}$

846 composition (Fig. 14A) with increasing P-T conditions southwards (Figs.21C and 22C). In white mica, the

847 modelled trend toward paragonitic muscovite along the $\mathrm{P}_{2}$ field gradient (Figs.21E and 22E) closely

848 matches the measured increase in Na content (Fig.17F). The thermodynamic modelling results therefore

849 demonstrate that the district-scale compositional trends documented for biotite and white mica along the

850 metamorphic gradient in non-altered metasedimentary rocks were most likely the product of the

851 increasing P-T conditions southwards.

852 Discussion

\subsection{Timing relationships}

The precise timing of gold mineralization in metamorphosed terranes has long been a source of debate

855 and remains controversial in the case of many Archean deposits due to the interplay of deformation,

856 hydrothermal and metamorphic events (Marshall et al., 2000; Ridley et al., 2000; Groves et al., 2003;

857 Goldfarb et al., 2005). Deciphering the temporal relationships of ore-forming processes with respect to

858 deformation and metamorphism is nonetheless critical to the interpretation of the complex mineralogical

859 patterns that result from the superposition of these events.

860 The geometry of the Canadian Malartic deposit consists of elongate, lenticular ore zones hosted by

861 second-order structures associated with $\mathrm{D}_{2}$ deformation. The NW-SE deformation zones are manifested

862 by a series of faulted $\mathrm{S}$-shaped $\mathrm{F}_{2}$ folds, with an axial-planar cleavage oriented parallel to the regional 
foliation $\mathrm{S}_{2}$ (Fig.4). High-strain zones in sheared $\mathrm{F}_{2}$ fold hinge zones locally host fault-fill quartzdominated auriferous veins (e.g., in the Gilbert and Gouldie zones), which occur orthogonal to bedding $\left(\mathrm{S}_{0}\right)$ and subparallel to $\mathrm{S}_{2}$ (De Souza et al., 2016). Ore-stage (v2) stockwork veinlets are typically axialplanar to $F_{2}$ folds, as they were preferentially emplaced and locally transposed by the $S_{2}$ fabric; they were also locally folded and dismembered by $\mathrm{D}_{2}$ deformation. Hydrothermal alteration occurred synchronously with deformation, as demonstrated by the preferential alignment of alteration biotite and white mica parallel to the $S_{2}$ foliation, and crystallization of alteration phases (including biotite, microcline and carbonates) in pyrite pressure shadows.

A broad synchronicity of the $\mathrm{M}_{2}$ metamorphic event with respect to the $\mathrm{D}_{2}$ deformation is indicated by the axial-planar setting of the $\mathrm{S}_{2}$ foliation in $\mathrm{F}_{2}$ folds. Textural relationships of garnet and staurolite porphyroblasts in the lower amphibolite facies further suggest that peak metamorphism was coeval with, or closely followed $\mathrm{D}_{2}$ deformation (Piette-Lauzière, 2017). In addition, hydrothermal alteration at Canadian Malartic occurred under thermal conditions that were broadly compatible with those of metamorphism, as suggested by the overlap between ore formation temperature constraints $\left(\sim 475^{\circ} \mathrm{C}\right.$; Helt et al., 2014) and the P-T conditions for upper greenschist metamorphism inferred from pseudosection modelling. Mineralogical, textural and structural observations are thus consistent with a syn-kinematic $\left(\mathrm{D}_{2}\right)$, early- to syn-peak metamorphic $\left(\mathrm{M}_{2}\right)$ timing for the main ore-forming event at Canadian Malartic. This interpretation is supported by geochronological data (Fig.3), suggesting a gold mineralization event at $2664 \pm 11 \mathrm{Ma}$ (Re-Os on molybdenite; De Souza et al., 2016) and peak metamorphism at 2657 \pm 7 Ma in the amphibolite facies immediately south of the deposit (Lu-Hf on garnet; Piette-Lauzière, 2017). The time gap between the inferred ore-stage event and quartz monzodiorite emplacement (2677-2679 Ma; Clark et al., in prep.) seems to rule out a direct genetic relationship between gold mineralization and the host intrusions. The geochronological data therefore suggest a metamorphic overprint of the main oreforming event, but the errors associated with the age determinations also allow for a broad overlap between peak metamorphism and mineralization (Fig.3).

\subsection{Expression and preservation of a hydrothermal signature in the micas}

The broad alteration halo around the Canadian Malartic deposit is delineated by steep sulfidation and oxidation gradients that decrease outwards from the ore zones. These variations are manifested by abrupt transitions in sulfide and Fe-Ti oxide mineralogy away from the hydrothermal fluid pathways. Within the 
ore shell, the sulfide-oxide mineralogy in the altered metasedimentary rocks is dominated by pyrite and rutile, indicating relatively oxidizing ore-forming conditions. Rutile in altered rocks is enriched in $\mathrm{W}$ (Clark et al., in prep.) and was stabilized at the expense of ilmenite under high $\sum a \mathrm{~S}-\mathrm{fO}_{2}$ conditions through the reaction $\mathrm{FeTiO}_{3}+2 \mathrm{H}_{2} \mathrm{~S}+0.5 \mathrm{O}_{2}=\mathrm{FeS}_{2}+\mathrm{TiO}_{2}+2 \mathrm{H}_{2} \mathrm{O}$ (e.g., Nesbitt, 1986a,b). In contrast, ilmenite is the dominant oxide in metasedimentary rocks beyond the ore shell, and sulfides are characterized by variable degrees of replacement of pyrite by pyrrhotite \pm (chalcopyrite-pentlandite). This latter texture reflects the breakdown of pyrite to pyrrhotite with progressive metamorphic dehydration under reducing conditions, e.g., $\mathrm{FeS}_{2}+\mathrm{H}_{2} \mathrm{O}=\mathrm{FeS}+\mathrm{H}_{2} \mathrm{~S}+0.5 \mathrm{O}_{2}$ (Pitcairn et al., 2006; Thomas et al., 2011). In the altered rocks, the physico-chemical conditions were buffered to relatively high values of $\sum a \mathrm{~S}-f \mathrm{O}_{2}$, which inhibited the conversion of pyrite to pyrrhotite during metamorphism (e.g., Heiligmann et al., 2008).

The preservation of a sulfidation-oxidation halo around the Canadian Malartic deposit greatly affected the equilibria among sulfides, oxides and silicates during coeval and/or subsequent metamorphism. Increasing $\sum a \mathrm{~S}-f \mathrm{O}_{2}$ conditions, as well as high fluid-rock ratios proximal to the hydrothermal fluid pathways were the main factors controlling sulfur metasomatism (Fig.12B), and caused pyrite to be gradually stabilized over biotite as the dominant Fe-bearing mineral phase. The strong positive correlation between whole-rock sulfur content and biotite Mg\# (Fig.16) indicates that iron sequestration in pyrite promoted the stability of magnesian biotite compositions in altered rocks (e.g., Hezarkhani et al, 1999; Spry, 2000). The broad covariation between fluorine and Mg\# in biotite (Fig.15D) further suggests that fluorine incorporation was facilitated in biotite of magnesian composition (Fig.15A), consistent with the Fe-F avoidance feature as described by Munoz (1984). Furthermore, the positive correlation between bulk-rock and biotite fluorine contents (Fig. 15C) demonstrates that Fe-F avoidance in biotite was key to the preservation of a fluorine metasomatic halo around the deposit, which was presumably associated with the circulation of a fluorine-rich oxidized ore-forming fluid (Fig.15B).

Metamorphic pseudosection modelling indicates that the district-scale compositional trends documented along the metamorphic gradient for biotite and white mica in non-altered metasedimentary rocks, including the progression of the Tschermak substitution towards more aluminous compositions, were most likely the product of increasing metamorphic P-T conditions southwards (Figs.21-22). The continuity of these trends along the $\mathrm{P}_{2}$ section from unaltered metasedimentary rocks through to distal and 
proximal hydrothermally-altered zones further supports a late-timing for peak metamorphism with respect to alteration (Figs.13-14, 17-18). Increasing proximity to hydrothermal fluid pathways, however, was

923 manifested at the drill-hole scale by a Tschermak-controlled decrease in the total Al concentration of 924 biotite and white mica (see Fig.11), coincident with increases in $\mathrm{Si}$ and Fe+Mg contents. Equilibrium relationships among $\mathrm{K}$-silicates in hydrothermally-altered zones (e.g., progressive microclinization towards hydrothermal fluid corridors) likely buffered physico-chemical conditions during metamorphism, which preserved the original alteration zonation pattern from proximal potassic to distal potassic-sericitic zones. Decreasing activity gradients of $a \mathrm{~K}^{+}$and/or $\mathrm{pH}$ away from the mineralizing fluid pathways were the main controls on the Tschermak-exchange compositional trends and potassium metasomatism in 931 potassium-rich ore-forming fluid.

932 Mica mineral chemistry is therefore a sensitive indicator of hydrothermal and metamorphic processes 933 in the Malartic district. On the basis of the compositional characteristics presented in this study, district934 scale hyperspectral investigations of biotite and white mica (Lypaczewski et al., in prep.) permitted the 935 delineation of a $>10 \mathrm{~km}$ hydrothermal footprint extending laterally parallel to the main $\mathrm{S}_{2}$ foliation, which could be efficiently discriminated from the regional metamorphic signal. These results demonstrate that

937 micas provide a powerful and cost-efficient exploration tool, which should prove particularly useful for 938 defining mineral-chemical vectors to ore and mapping the zonation of alteration features that characterize the footprint of other major gold systems hosted in metamorphic terranes.

\section{Conclusions}

942 the mineralizing conditions at Canadian Malartic and can be used to develop vectors toward ore zones.

943 Micas record the evolution of physico-chemical conditions associated with fluid-rock interactions, as well

944 as metasomatic processes (e.g., sulfur and halogen additions). A systematic increase in biotite $\mathrm{Mg \#}$ was

945 associated with increasing $\sum a \mathrm{~S}-\mathrm{fO}_{2}$ conditions, reflecting greater degrees of sulfur metasomatism adjacent 946 to fluid pathways. The Mg-rich biotite composition associated with alteration, in turn, facilitated the 947 incorporation of fluorine (Fe-F avoidance feature), thus permitting the preservation of a fluorine 948 metasomatic halo through coeval and/or subsequent peak metamorphism. Hydrothermal alteration was 949 also manifested in biotite and white mica compositions by a Tschermak-controlled decrease in Al content, 
which resulted from decreases in $a \mathrm{~K}^{+}$and/or $\mathrm{pH}$ upon gradual buffering of the ore-forming fluid with the metasedimentary host-rock.

The delineation of vectors that are useful for exploration for Canadian Malartic-type and related deposits is complicated by the mineralogical interference patterns resulting from the overlap and/or overprint of peak metamorphism with respect to gold mineralization. Thermodynamic modelling demonstrates that the district-scale compositional trends documented along the metamorphic gradient for biotite and white mica in non-altered metasedimentary rocks, including the progression of a Tschermak exchange reaction towards more aluminous compositions, were most likely the product of the increasing P-T conditions southwards.

This study shows that biotite and white mica compositions provide a valuable tool with which to define fluid pathways in the Canadian Malartic hydrothermal system. These parameters are particularly useful, in metamorphic terranes, for mapping the zonation of alteration features that characterize the footprint of major gold deposits, as they typically offer an excellent means for defining mineral-chemical vectors to ore.

\section{Acknowledgements}

Financial support for this study was provided by grants from the Natural Sciences and Engineering Council of Canada (NSERC) and the Canada Mining Innovation Council through the NSERC Collaborative Research and Development Program. The SEG is acknowledged for providing a research grant to the first author. We are grateful to Canadian Malartic Corporation for offering logistical support, and for providing access to the drillcore database, and to François Bouchard, Kayla Helt, Carl Corriveau, Pierre de Chavigny, Johan Bergé, Matthieu Dessureault, Alain Hébert, René de Carufel, Antoine Sweet, Christian Tessier and Donald Gervais for assistance and advice during field work. Thomas Raskevicius and Guillaume Clouette-Gauthier are acknowledged for helping with fieldwork and drillcore sampling. Lang Shi is thanked for assistance with microprobe analyses. Steve Piercey and Matthew Crocker provided pXRF whole-rock analyses. We thank our fellow researchers of the Mineral Exploration Footprints Research Network (http://www.cmic-footprints.ca/) and industry sponsors for fruitful discussions throughout the course of this project: Gema Olivo, Robert Wares, Howard Poulsen, Marc Bardoux, Benoit Rivard, François Robert, Didier Béziat, Georges Beaudoin, Kurt Kyser, Jean-François Couture, Alan Galley, Michael Lesher and Charles Lafrenière-Bérubé provided continuous support and 
979 feedback. We are also indebted to John Walshe for a very thorough and constructive review. Finally, we 980 acknowledge researchers of the Targeted Geoscience Initiative (TGI-4), Stéphane De Souza, Benoit

981 Dubé, Patrick Mercier-Langevin, and geologists of the Ministère de l'Énergie et des Ressources

982 Naturelles du Québec, Pierre Pilote and Patrice Roy, for constructive discussions. NSERC-CMIC Mineral 983 Exploration Footprints Project Contribution 155. 


\section{References}

Ayati, F., F. Yavuz, M. Noghreyan, H. A. Haroni, and R. Yavuz (2008), Chemical characteristics and composition of hydrothermal biotite from the Dalli porphyry copper prospect, Arak, central province of Iran, Miner Petrol, 94(1-2), 107-122.

Ayer, J., Y. Amelin, F. Corfu, S. Kamo, J. Ketchum, K. Kwok, and N. Trowell (2002), Evolution of the southern Abitibi greenstone belt based on $\mathrm{U}-\mathrm{Pb}$ geochronology: autochthonous volcanic construction followed by plutonism, regional deformation and sedimentation, Precambrian Research, 115(1), 63-95.

Ayer, J. A., et al. (2005), Overview of results from the Greenstone Architecture Project: Discover Abitibi Initiative, Ontario Geological Survey, Open File Report 6154, 146.

Bateman, R., J. A. Ayer, B. Dubé, and M. A. Hamilton (2005), The Timmins-Porcupine gold camp, northern Ontario: the anatomy of an Archaean greenstone belt and its gold mineralization: Discover Abitibi Initiative Ontario Geological Survey, Open File Report 6158, 90

Bath, A. B., et al. (2013), Biotite and Apatite as Tools for Tracking Pathways of Oxidized Fluids in the Archean East Repulse Gold Deposit, Australia, Economic Geology, 108(4), 667-690.

Beaulieu, C. (2010), Perigranitic gold deposit of Canadian Malartic (Québec): 3D modeling contribution to metallogenic interpretation Mémoire de Maîtrise en Sciences de la Terre, Université du Québec à Montréal.

Benn, K., W. Miles, M. R. Ghassemi, and J. Gillett (1994), Crustal structure and kinematic framework of the northwestern Pontiac Subprovince, Quebec: an integrated structural and geophysical study, Canadian Journal of Earth Sciences, 31(2), 271-281.

Boomeri, M., K. Nakashima, and D. R. Lentz (2009), The Miduk porphyry Cu deposit, Kerman, Iran: A geochemical analysis of the potassic zone including halogen element systematics related to $\mathrm{Cu}$ mineralization processes, Journal of Geochemical Exploration, 103(1), 17-29.

Camiré, G. E., and J. P. Burg (1993), Late Archaean thrusting in the northwestern Pontiac Subprovince, Canadian Shield, Precambrian Research, 61(1-2), 51-66.

Camiré, G. E., M. R. Laflèche, and J. N. Ludden (1993a), Archaean metasedimentary rocks from the northwestern Pontiac Subprovince of the Canadian Shield: chemical characterization, weathering and modelling of the source areas, Precambrian Research, 62(3), 285-305.

Camiré, G. E., J. N. Ludden, M. R. Laflèche, and J.-P. Burg (1993b), Mafic and ultramafic amphibolites from the northwestern Pontiac Subprovince: chemical characterization and implications for tectonic setting, Canadian Journal of Earth Sciences, 30(6), 1110-1122.

Card, K. (1990), A review of the Superior Province of the Canadian Shield, a product of Archean accretion, Precambrian Research, 48(1-2), 99-156.

Card, K. D., and K. H. Poulsen (1998), Geology and mineral deposits of the Superior province of the Canadian Shield, Geology of Canada Series no. 7; in, Geology of the Precambrian Superior and Grenville provinces and Precambrian fossils in North America (Lucas, S. B; St-Onge, M. R. Geological Survey of Canada), p. 15-204.

Chabu, M. (1995), The geochemistry of phlogopite and chlorite from the Kipushi $\mathrm{Zn}-\mathrm{Pb}-\mathrm{Cu}$ deposit, Shaba, Zaire, The Canadian Mineralogist, 33(3), 547-558.

Clark, M. E., D. M. Carmichael, C. J. Hodgson, and M. Fu (1989), Wall-rock alteration, Victory Gold Mine, Kambalda, Western Australia: processes and P-T-X(CO2) conditions of metasomatism, Economic Geology Monograph 6, 445-459. 
Clark, R. N., T. V. V. King, M. Klejwa, G. A. Swayze, and N. Vergo (1990), High spectral resolution reflectance spectroscopy of minerals, Journal of Geophysical Research: Solid Earth, 95, 12653-12680.

Cleverley, J. S., and N. H. S. Oliver (2005), Comparing closed system, flow-through and fluid infiltration geochemical modelling: examples from $\mathrm{K}$-alteration in the Ernest Henry Fe-oxide-Cu-Au system, Geofluids, 5(4), 289-307.

Connolly, J. A. D., and K. Petrini (2002), An automated strategy for calculation of phase diagram sections and retrieval of rock properties as a function of physical conditions, Journal of Metamorphic Geology, 20(7), 697-708.

Connolly, J. A. D. (2005), Computation of phase equilibria by linear programming: A tool for geodynamic modeling and its application to subduction zone decarbonation, Earth and Planetary Science Letters, $236(1), 524-541$.

Corfu, F., S. L. Jackson, and R. H. Sutcliffe (1991), U-Pb ages and tectonic significance of late Archean alkalic magmatism and nonmarine sedimentation: Timiskaming Group, southern Abitibi belt, Ontario, Canadian Journal of Earth Sciences, 28(4), 489-503.

Corfu, F. (1993), The evolution of the southern Abitibi greenstone belt in light of precise U-Pb geochronology, Economic Geology, 88(6), 1323-1340.

Couture, J.-F., P. Pilote, N. Machado, and J.-P. Desrochers (1994), Timing of gold mineralization in the Val-d'Or District, southern Abitibi Belt; evidence for two distinct mineralizing events, Economic Geology, 89(7), 1542-1551.

Daigneault, R., W. U. Mueller, and E. H. Chown (2002), Oblique Archean subduction: accretion and exhumation of an oceanic arc during dextral transpression, Southern Volcanic Zone, Abitibi Subprovince Canada, Precambrian Research, 115(1), 261-290.

Davis, D. W., E. S. Schandl, and H. A. Wasteneys (1994), U-Pb dating of minerals in alteration halos of Superior Province massive sulfide deposits: syngenesis versus metamorphism, Contrib Mineral Petrol, $115(4), 427-437$.

Davis, D. W. (2002), U-Pb geochronology of Archean metasedimentary rocks in the Pontiac and Abitibi subprovinces, Quebec, constraints on timing, provenance and regional tectonics, Precambrian Research, 115(1), 97-117.

Davis, W. J., S. Lacroix, C. Gariépy, and N. Machado (2000), Geochronology and radiogenic isotope geochemistry of plutonic rocks from the central Abitibi subprovince: significance to the internal subdivision and plutono-tectonic evolution of the Abitibi belt, Canadian Journal of Earth Sciences, 37(23), 117-133.

De Souza, S., B. Dubé, V. J. McNicoll, C. Dupuis, P. Mercier-Langevin, R. A. Creaser, and I. M. Kjarsgaard (2016), Geology and hydrothermal alteration of the world-class Canadian Malartic gold deposit: genesis of an Archean stockwork-disseminated gold deposit in the Abitibi Greenstone Belt, Québec, Reviews in Economic Geology, Vol.19, 29.

Dempster, T. J. (1992), Zoning and recrystallization of phengitic micas: implications for metamorphic equilibration, Contrib Mineral Petrol, 109(4), 526-537.

Derry, D. R. (1939), The geology of the Canadian Malartic gold mine, N. Quebec, Economic Geology, 34(5), 495-523.

Desrochers, J.-P., and C. Hubert (1996), Structural evolution and early accretion of the Archean Malartic Composite Block, southern Abitibi greenstone belt, Quebec, Canada, Canadian Journal of Earth Sciences, 33(11), 1556-1569. 
Dimroth, E., L. Imreh, N. Goulet, and M. Rocheleau (1983a), Evolution of the south-central segment of the Archean Abitibi Belt, Quebec. Part II: Tectonic evolution and geomechanical model, Canadian Journal of Earth Sciences, 20(9), 1355-1373.

Dimroth, E., L. Imreh, N. Goulet, and M. Rocheleau (1983b), Evolution of the south-central segment of the Archean Abitibi Belt, Quebec. Part III: Plutonic and metamorphic evolution and geotectonic model, Canadian Journal of Earth Sciences, 20(9), 1374-1388.

Ducharme, Y., R. K. Stevenson, and N. Machado (1997), Sm-Nd geochemistry and U-Pb geochronology of the Preissac and Lamotte leucogranites, Abitibi Subprovince, Canadian Journal of Earth Sciences, 34(8), 1059-1071

Duke, E. F. (1994), Near infrared spectra of muscovite, Tschermak substitution, and metamorphic reaction progress: Implications for remote sensing, Geology, 22(7), 621-624.

Fallara, F., P. Simon-Ross, and R. Sansfaçon (2000), Caractérisation géochimique, pétrographique et structurale : nouveau modèle métallogénique du camp minier de Malartic, Géologie Québec, MB2000-15.

Feng, R., and R. Kerrich (1992), Geodynamic evolution of the southern Abitibi and Pontiac terranes: evidence from geochemistry of granitoid magma series (2700-2630Ma), Canadian Journal of Earth Sciences, 29(10), 2266-2286.

Feng, R., J. Fan, and R. Kerrich (1993), Noble metal abundances and characteristics of six granitic magma series, Archean Abitibi Belt, Pontiac Subprovince; relationships to metallogeny and overprinting of mesothermal gold deposits, Economic Geology, 88(6), 1376-1401.

Franklin, J. M., H. L. Gibson, I. R. Jonasson, and A. G. Galley (2005), Volcanogenic massive sulfide deposits, Economic Geology and the bulletin of the Society of Economic Geologists, 100th Anniversary Volume 1905-2005; In: Hedenquist, J.W.; Thompson, J.F.H.; Goldfarb, R.J.; and Richards, J.P. (eds.), 523-560.

Frieman, B. M., Y. D. Kuiper, N. M. Kelly, T. Monecke, and A. Kylander-Clark (2017), Constraints on the geodynamic evolution of the southern Superior Province: U-Pb LA-ICP-MS analysis of detrital zircon in successor basins of the Archean Abitibi and Pontiac subprovinces of Ontario and Quebec, Canada, Precambrian Research, 292, 398-416.

Froese, E. (1971), The graphical representation of sulfide-silicate phase equilibria, Economic Geology, 66(2), 335-341.

Fuhrman, M. L., and D. H. Lindsley (1988), Ternary-feldspar modeling and thermometry, American Mineralogist, 73(3-4), 201-215.

Gaillard, N., A. E. Williams-Jones, J. R. Clark, S. Salvi, D. Béziat, P. Lypaczewski, S. Perrouty, and R. L. Linnen (2015), Mineralogical and geochemical vectors to ore: the alteration halo of the Canadian Malartic gold deposit, Proceedings of the 13th, Biennial SGA Meeting, Nancy, France., Vol.2 461-464.

Galley, A. G., and O. Van Breemen (2002), Timing of synvolcanic magmatism in relation to base-metal mineralization, Rouyn-Noranda, Abitibi volcanic belt, Quebec, Radiogenic Age and Isotopic Studies: Report 15, Geological Survey of Canada, Current Research 2002-F8, 9p.

Gao, J.-F., S. E. Jackson, B. Dubé, D. J. Kontak, and S. De Souza (2015), Genesis of the Canadian Malartic, Côté Gold, and Musselwhite gold deposits: insights from LA-ICP-MS element mapping of pyrite, Targeted Geoscience Initiative 4: Contributions to the Understanding of Precambrian Lode Gold Deposits and implications for exploration B. Dubé and P. Mercier-Langevin; Geological Survey of Canada, Open File 7852, 157-175. 
Ghassemi, M. R. (1996), Tectonic evolution of the Late Archean Pontiac Subprovince, Superior Province, Canada: Structural, metamorphic and geochronological studies, Ph.D. thesis, University of Ottawa.

Goldfarb, R. J., T. Baker, B. Dube, D. I. Groves, C. J. R. Hart, and P. Gosselin (2005), Distribution, character, and genesis of gold deposits in metamorphic terranes, Economic Geology and the bulletin of the Society of Economic Geologists, 100th Anniversary Volume 1905-2005; In: Hedenquist, J.W.; Thompson, J.F.H.; Goldfarb, R.J.; and Richards, J.P. (eds.), 407-450.

Goulet, N. (1978), Stratigraphy and structural relationships across the Cadillac-Larder lake fault, RouynBeauchastel area, Québec, Ministère des Ressources Naturelles du Québec, DP-602, 141.

Groves, D. I., R. J. Goldfarb, F. Robert, and C. J. R. Hart (2003), Gold Deposits in Metamorphic Belts: Overview of Current Understanding, Outstanding Problems, Future Research, and Exploration Significance, Economic Geology, 98(1), 1-29.

Guidotti, C. V. (1984), Micas in metamorphic rocks, in Micas, Bailey, S.W. (Ed.), Reviews in Mineralogy, Vol.13, Mineralogical Society of America, 357-467.

Gunning, H. C., and J. W. Ambrose (1943), Région de Malartic, Québec, Commission géologique du Canada, Mémoire 222, 162.

Gunow, A. J., S. Ludington, and J. L. Munoz (1980), Fluorine in micas from the Henderson molybdenite deposit, Colorado, Economic Geology, 75(8), 1127-1137.

Halley, S., J. H. Dilles, and R. M. Tosdal (2015), Footprints: hydrothermal alteration and geochemical dispersion around porphyry copper deposits, SEG newsletter, Vol.100.

Heiligmann, M., A. E. Williams-Jones, and J. R. Clark (2008), The Role of Sulfate-Sulfide-OxideSilicate Equilibria in the Metamorphism of Hydrothermal Alteration at the Hemlo Gold Deposit, Ontario, Economic Geology, 103(2), 335-351.

Helt, K. M., A. E. Williams-Jones, J. R. Clark, B. A. Wing, and R. P. Wares (2014), Constraints on the Genesis of the Archean Oxidized, Intrusion-Related Canadian Malartic Gold Deposit, Quebec, Canada, Economic Geology, 109(3), 713-735.

Henry, D. J., C. V. Guidotti, and J. A. Thomson (2005), The Ti-saturation surface for low-to-medium pressure metapelitic biotites: Implications for geothermometry and Ti-substitution mechanisms, American Mineralogist, 90(2-3), 316-328.

Hezarkhani, A., E. A. Williams-Jones, and H. C. Gammons (1999), Factors controlling copper solubility and chalcopyrite deposition in the Sungun porphyry copper deposit, Iran, Mineralium Deposita, 34(8), 770-783.

Holland, T. J. B., and R. Powell (1998), An internally consistent thermodynamic data set for phases of petrological interest, Journal of Metamorphic Geology, 16(3), 309-343.

Holland, T. J. B., and R. Powell (2011), An improved and extended internally consistent thermodynamic dataset for phases of petrological interest, involving a new equation of state for solids, Journal of Metamorphic Geology, 29(3), 333-383.

Hunt, G. R. (1977), Spectral signatures of particulate minerals in the visible and near infrared, Geophysics, 42(3), 501-513.

Ikeda, T. (1998), Progressive sequence of reactions of the Ryoke metamorphism in the Yanai district, southwest Japan: the formation of cordierite, Journal of Metamorphic Geology, 16(1), 39-52. 
Johnson, J. W., E. H. Oelkers, and H. C. Helgeson (1992), SUPCRT92: A software package for calculating the standard molal thermodynamic properties of minerals, gases, aqueous species, and reactions from 1 to 5000 bar and 0 to $1000^{\circ} \mathrm{C}$, Computers \& Geosciences, 18(7), 899-947.

Jolly, W. T. (1978), Metamorphic history of the Archean Abitibi belt, Metamorphism in the Canadian Shield; Edited by J.A. Fraser and W.W. Heywood., Geological Survey of Canada (Paper 78-10), 63-78.

Kimura, G., J. N. Ludden, J. P. Desrochers, and R. Hori (1993), A model of ocean-crust accretion for the Superior province, Canada, Lithos, 30(3), 337-355.

Korzhinskii, D. S. (1968), The theory of metasomatic zoning, Mineralium Deposita, 3(3), 222-231.

Machado, N., M. Rive, C. Gariépy, and A. Simard (1991), U-Pb geochronology of granitoids from the Pontiac Subprovince: preliminary results, Geological Association of Canada, Program with Abstracts, 16(78).

MacLean, W. H., and T. J. Barrett (1993), Lithogeochemical techniques using immobile elements, Journal of Geochemical Exploration, 48(2), 109-133.

Marshall, B., and P. G. Spry (2000), Discriminating between regional metamorphic remobilization and syntectonic emplacement in the genesis of massive sulfide ores, Reviews in Economic Geology, Vol.11, $39-79$.

McCuaig, C. T., and R. Kerrich (1998), P-T-t-deformation - fluid characteristics of lode gold deposits: evidence from alteration systematics, Ore Geology Reviews, 12(6), 381-453.

McLeod, R. L., A. R. Gabell, A. A. Green, and V. Gardavsky (1987), Chlorite infrared spectral data as proximity indicators of volcanic massive sulphide mineralisation, Proc. PACRIM Congress, Gold Coast, Australia, 321-324.

Mercier-Langevin, P., B. Dubé, M. D. Hannington, D. W. Davis, B. Lafrance, and G. Gosselin (2007), The LaRonde Penna Au-Rich Volcanogenic Massive Sulfide Deposit, Abitibi Greenstone Belt, Quebec: Part I. Geology and Geochronology, Economic Geology, 102(4), 585-609.

Mikucki, E. J., and J. R. Ridley (1993), The hydrothermal fluid of Archean lode-gold deposits at different metamorphic grades: compositional constraints from ore and wallrock alteration assemblages, Mineralium Deposita, 28(6), 469-481.

Mikucki, E. J. (1998), Hydrothermal transport and depositional processes in Archean lode-gold systems: A review, Ore Geology Reviews, 13(1-5), 307-321.

Miyashiro, A., and F. Shido (1985), Tschermak Substitution in Low- and Middle-grade Pelitic Schists, Journal of Petrology, 26(2), 449-487.

Morasse, S., H. A. Wasteneys, M. Cormier, H. Helmstaedt, and R. Mason (1995), A pre-2686 Ma intrusion-related gold deposit at the Kiena Mine, Val d'Or, Quebec, southern Abitibi Subprovince, Economic Geology, 90(5), 1310-1321.

Mortensen, J. K. (1993), U-Pb geochronology of the eastern Abitibi Subprovince. Part 2: Noranda Kirkland Lake area, Canadian Journal of Earth Sciences, 30(1), 29-41.

Mortensen, J. K., and K. D. Card (1993), U-Pb age constraints for the magmatic and tectonic evolution of the Pontiac Subprovince, Quebec, Canadian Journal of Earth Sciences, 30, 1970-1980.

Munoz, J. L. (1984), F-OH and Cl-OH exchange in micas with applications to hydrothermal ore deposits, in Micas, Bailey, S.W. (Ed.), Reviews in Mineralogy, Vol.13, Mineralogical Society of America, 469-493. 
Munoz, J. L. (1992), F and Cl contents of hydrothermal biotites: a reevaluation, GSA Abstract, Prog. 22(A135).

Nesbitt, B. E., and W. C. Kelly (1980), Metamorphic zonation of sulfides, oxides, and graphite in and around the orebodies at Ducktown, Tennessee, Economic Geology, 75(7), 1010-1021.

Nesbitt, B. E. (1986a), Oxide-sulfide-silicate equilibria associated with metamorphosed ore deposits; Part I, Theoretical considerations, Economic Geology, 81(4), 831-840.

Nesbitt, B. E. (1986b), Oxide-sulfide-silicate equilibria associated with metamorphosed ore deposits; Part II, Pelitic and felsic volcanic terrains, Economic Geology, 81(4), 841-856.

Neumayr, P., J. Walshe, S. Hagemann, K. Petersen, A. Roache, P. Frikken, L. Horn, and S. Halley (2008), Oxidized and reduced mineral assemblages in greenstone belt rocks of the St. Ives gold camp, Western Australia: vectors to high-grade ore bodies in Archaean gold deposits?, Mineralium Deposita, 43(3), 363-371.

Oliver, N. H. S., J. S. Cleverley, G. Mark, P. J. Pollard, B. Fu, L. J. Marshall, M. J. Rubenach, P. J. Williams, and T. Baker (2004), Modeling the Role of Sodic Alteration in the Genesis of Iron OxideCopper-Gold Deposits, Eastern Mount Isa Block, Australia, Economic Geology, 99(6), 1145-1176.

Pamer, L. (2013), Determination of Fluoride and Chloride Concentrations in Geological Materials by Ion Selective Electrode, Geoscience Laboratories, Ontario Geological Survey.

Pattison, R. M. D. (1987), Variations in $\mathrm{Mg} /(\mathrm{Mg}+\mathrm{Fe}), \mathrm{F}$, and $(\mathrm{Fe}, \mathrm{Mg}) \mathrm{Si}=2 \mathrm{Al}$ in pelitic minerals in the Ballachulish thermal aureole, Scotland, American Mineralogist, 72, 255-272.

Pauling, L. (1929), The principles determining the structure of complex ionic crystals, Journal of the American Chemical Society, 51(4), 1010-1026.

Pearce, M. A., A. J. R. White, L. A. Fisher, R. M. Hough, and J. S. Cleverley (2015), Gold deposition caused by carbonation of biotite during late-stage fluid flow, Lithos, 239, 114-127.

Perrouty, S., et al. (2017), Structural setting for Canadian Malartic style of gold mineralization in the Pontiac Subprovince, south of the Cadillac Larder Lake Deformation Zone, Québec, Canada, Ore Geology Reviews, 84, 185-201.

Piercey, S. J., and M. C. Devine (2014), Analysis of powdered reference materials and known samples with a benchtop, field portable X-ray fluorescence (pXRF) spectrometer: evaluation of performance and potential applications for exploration lithogeochemistry, Geochemistry: Exploration, Environment, Analysis, 14(2), 139-148.

Piette-Lauzière, N. (2017), Métamorphisme régional du nord-est de la Sous-province de Pontiac, Abitibi, Québec, Mémoire de Maîtrise en Sciences de la Terre, Université Laval.

Pilote, P., J. F. Couture, J. P. Desrochers, N. Machado, and P. Pelz (1993), Minéralisations aurifères multiphasées dans la région de Val d 'Or : l'exemple de la mine Norlartic, Ministère de l'Énergie et des Ressources, Québec Rapport DV 93-03, 61-66.

Pilote, P. (2014), Géologie Malartic, Ministère des Ressources Naturelles du Québec. Scale 1:20000, MB 2000-09, Map CG-32D01D-2013-01.

Pilote, P., R. Daigneault, J. David, and V. McNicoll (2014), L'architecture des groupes de Malartic, de Piché et de Cadillac et de la Faille de Cadillac, Abitibi : révision géologique, nouvelles datations et interprétations, Abstract DV 2014-07. 
Pitcairn, I. K., D. A. H. Teagle, D. Craw, G. R. Olivo, R. Kerrich, and T. S. Brewer (2006), Sources of Metals and Fluids in Orogenic Gold Deposits: Insights from the Otago and Alpine Schists, New Zealand, Economic Geology, 101(8), 1525-1546.

Powell, W. G., D. M. Carmichael, and C. J. Hodgson (1995), Conditions and timing of metamorphism in the southern Abitibi greenstone belt, Quebec, Canadian Journal of Earth Sciences, 32(6), 787-805.

Powell, R., R. W. White, E. C. R. Green, T. J. B. Holland, and J. F. A. Diener (2014), On parameterizing thermodynamic descriptions of minerals for petrological calculations, Journal of Metamorphic Geology, $32(3), 245-260$.

Ridley, J., D. I. Groves, and J. T. Knight (2000), Gold deposits in amphibolite and granulite facies terranes of the Archean Yilgarn Craton, Western Australia: evidence and implications of synmetamorphic mineralization, Reviews in Economic Geology, Vol.11, 265-290.

Robert, F., and K. H. Poulsen (1997), World-class Archaean gold deposits in Canada: An overview, Australian Journal of Earth Sciences, 44(3), 329-351.

Robert, F. (2001), Syenite-associated disseminated gold deposits in the Abitibi greenstone belt, Canada, Mineralium Deposita, 36(6), 503-516.

Robert, F., K. H. Poulsen, K. F. Cassidy, and C. J. Hodgson (2005), Gold Metallogeny of the Superior and Yilgarn Cratons, Economic Geology and the bulletin of the Society of Economic Geologists, 100th Anniversary Volume 1905-2005; In: Hedenquist, J.W.; Thompson, J.F.H.; Goldfarb, R.J.; and Richards, J.P. (eds.), 1001-1033.

Robie, R. A., and B. S. Hemingway (1995), Thermodynamic properties of minerals and related substances at $298.15 \mathrm{~K}$ and $1 \mathrm{bar}\left(10^{\wedge} 5\right.$ pascals $)$ pressure and at higher temperatures, Report Rep. 2131.

Rosenberg, L. J., G. P. Spry, E. C. Jacobson, and M. F. Vokes (2000), The effects of sulfidation and oxidation during metamorphism on compositionally varied rocks adjacent to the Bleikvassli $\mathrm{Zn}-\mathrm{Pb}-(\mathrm{Cu})$ deposit, Nordland, Norway, Mineralium Deposita, 35(8), 714-726.

Sansfaçon, R. (1986), The Malartic district, in Hubert, C., and Robert, F., eds., Structure and gold, Rouyn to Val d'Or, Québec: Geological Association of Canada-Mineralogical Association of Canada Canadian Geophysical Union Joint Annual Meeting, Field Trip 14 Guidebook, Structure and gold, Rouyn to Val d'Or, Québec, 27-41.

Sansfaçon, R., M. Grant, and P. Trudel (1987a), Géologie de la mine Barnat - Sladen Malartic - District de Val d'Or, Série des manuscripts bruts - Direction Générale de l'Exploration Géologique et Minérale, $M B 87-41$.

Sansfaçon, R., M. Grant, and P. Trudel (1987b), Géologie de la mine Canadian Malartic - District de Val d'Or, Série des manuscripts bruts - Direction Générale de l'Exploration Géologique et Minérale, MB8726.

Sansfaçon, R., and C. Hubert (1990), The Malartic Gold District, Abitibi greenstone belt, Québec: Geological setting, structure and timing of gold emplacement Barnat, East-Malartic, Canadian Malartic and Sladen Mines. In: The northwestern Quebec polymetallic belt: a summary of 60 years of mining exploration, Rive, M., Verpealst, P., Gagnon, Y., Lulin, J.M., Riverin, G., Simard, A. (Eds.), Special Vol. 43., Canadian Institute of Mining and Metallurgy, 221-235.

Scott, C. R., W. U. Mueller, and P. Pilote (2002), Physical volcanology, stratigraphy, and lithogeochemistry of an Archean volcanic arc: evolution from plume-related volcanism to arc rifting of SE Abitibi Greenstone Belt, Val d'Or, Canada, Precambrian Research, 115(1-4), 223-260. 
Seedorff, E., and M. T. Einaudi (2004), Henderson Porphyry Molybdenum System, Colorado: I. Sequence and Abundance of Hydrothermal Mineral Assemblages, Flow Paths of Evolving Fluids, and Evolutionary Style, Economic Geology, 99(1), 3-37.

Selby, D., and B. E. Nesbitt (2000), Chemical composition of biotite from the Casino porphyry $\mathrm{Cu}-\mathrm{Au}-$ Mo mineralization, Yukon, Canada: evaluation of magmatic and hydrothermal fluid chemistry, Chemical Geology, 171(1-2), 77-93.

Shock, E. L., D. C. Sassani, M. Willis, and D. A. Sverjensky (1997), Inorganic species in geologic fluids: Correlations among standard molal thermodynamic properties of aqueous ions and hydroxide complexes, Geochimica et Cosmochimica Acta, 61(5), 907-950.

Shvarov, Y. V., and E. Bastrakov (1999), HCh: a software package for geochemical equilibrium modelling, User's guide. Australian Geological Survey Organisation. Science and Resources, Record 1999/25, $61 \mathrm{pp}$.

Simard, M., D. Gaboury, R. Daigneault, and P. Mercier-Langevin (2013), Multistage gold mineralization at the Lapa mine, Abitibi Subprovince: insights into auriferous hydrothermal and metasomatic processes in the Cadillac-Larder Lake Fault Zone, Mineralium Deposita, 48(7), 883-905.

Simpson, H. G. D., B. A. Thompson, and D. J. A. Connolly (2000), Phase relations, singularities and thermobarometry of metamorphic assemblages containing phengite, chlorite, biotite, K-feldspar, quartz and H2O, Contrib Mineral Petrol, 139(5), 555-569.

Spry, P. G. (2000), Sulfidation and oxidation haloes as guides in the exploration for metamorphosed massive sulfide ores, Reviews in Economic Geology, Vol.11, 149-161.

Sutcliffe, R. H., C. T. Barrie, D. R. Burrows, and G. P. Beakhouse (1993), Plutonism in the southern Abitibi Subprovince; a tectonic and petrogenetic framework, Economic Geology, 88(6), 1359-1375.

Thomas, H. V., R. R. Large, S. W. Bull, V. Maslennikov, R. F. Berry, R. Fraser, S. Froud, and R. Moye (2011), Pyrite and Pyrrhotite Textures and Composition in Sediments, Laminated Quartz Veins, and Reefs at Bendigo Gold Mine, Australia: Insights for Ore Genesis, Economic Geology, 106(1), 1-31.

Thompson (1979), The Tschermak substitution and reactions in pelitic schists, Problems in Physicochemical Petrology, Vol.1 (Zharikov, V. A., Fonorev, V. I, \& Korikovskii, J. P. (eds.), Academy of Sciences, Moscow, 146-159.

Thompson, P. H. (2005), A New Metamorphic Framework for Gold Exploration in the TimminsKirkland Lake Area, Western Abitibi Greenstone Belt: Discover Abitibi Initiative, Ontario Geological Survey, Open File Report 6162, 104.

Thurston, P. C., J. A. Ayer, J. Goutier, and M. A. Hamilton (2008), Depositional Gaps in Abitibi Greenstone Belt Stratigraphy: A Key to Exploration for Syngenetic Mineralization, Economic Geology, 103(6), 1097-1134.

Trudel, P., and R. Sansfaçon (1987), Géologie de la Mine East Malartic - Région de Val d'Or, Série des manuscripts bruts - Direction Générale de l'Exploration Géologique et Minérale, MM 87-25.

Trudel, P., and P. Sauvé (1992), Synthèse des caractéristiques géologiques des gisements d'or du district de Malartic, Direction Générale de l'Exploration Géologique et Minérale, MM 89-04.

White, R. W., R. Powell, T. J. B. Holland, and B. A. Worley (2000), The effect of TiO2 and Fe2O3 on metapelitic assemblages at greenschist and amphibolite facies conditions: mineral equilibria calculations in the system $\mathrm{K} 2 \mathrm{O}-\mathrm{FeO}-\mathrm{MgO}-\mathrm{A} 12 \mathrm{O} 3-\mathrm{SiO} 2-\mathrm{H} 2 \mathrm{O}-\mathrm{TiO} 2-\mathrm{Fe} 2 \mathrm{O} 3$, Journal of Metamorphic Geology, 18(5), 497-511. 
White, R. W., R. Powell, T. J. B. Holland, T. E. Johnson, and E. C. R. Green (2014), New mineral activity-composition relations for thermodynamic calculations in metapelitic systems, Journal of Metamorphic Geology, 32(3), 261-286.

White, R. W., R. Powell, and T. E. Johnson (2014), The effect of Mn on mineral stability in metapelites revisited: new a-x relations for manganese-bearing minerals, Journal of Metamorphic Geology, 32(8), 809-828.

Wilkinson, J. J., Z. Chang, D. R. Cooke, M. J. Baker, C. C. Wilkinson, S. Inglis, H. Chen, and J. Bruce Gemmell (2015), The chlorite proximitor: A new tool for detecting porphyry ore deposits, Journal of Geochemical Exploration, 152, 10-26.

Wilkinson, L., A. R. Cruden, and T. E. Krogh (1999), Timing and kinematics of Timiskaming deformation within the Larder Lake - Cadillac deformation zone, southwest Abitibi greenstone belt, Ontario, Canada, Canadian Journal of Earth Sciences, 36(4), 627-647.

Williams-Jones, A. E., R. J. Bowell, and A. A. Migdisov (2009), Gold in Solution, Elements, 5(5), 281287.

Wong, L., D. W. Davis, T. E. Krogh, and F. Robert (1991), U-Pb zircon and rutile chronology of Archean greenstone formation and gold mineralization in the Val d'Or region, Quebec, Earth and Planetary Science Letters, 104(2), 325-336.

Zaleski, E., E. Froese, and T. M. Gordon (1991), Metamorphic petrology of Fe-Zn-Mg-Al alteration at the Linda volcanogenic massive sulfide deposit, Snow Lake, Manitoba, The Canadian Mineralogist, 29(4), 995-1017.

Zaleski, E., O. Van Breemen, and V. L. Peterson (1999), Geological evolution of the Manitouwadge greenstone belt and Wawa-Quetico subprovince boundary, Superior Province, Ontario, constrained by U$\mathrm{Pb}$ zircon dates of supracrustal and plutonic rocks, Canadian Journal of Earth Sciences, 36(6), 945-966.

Zhu, C., and D. A. Sverjensky (1992), F-Cl-OH partitioning between biotite and apatite, Geochimica et Cosmochimica Acta, 56(9), 3435-3467 


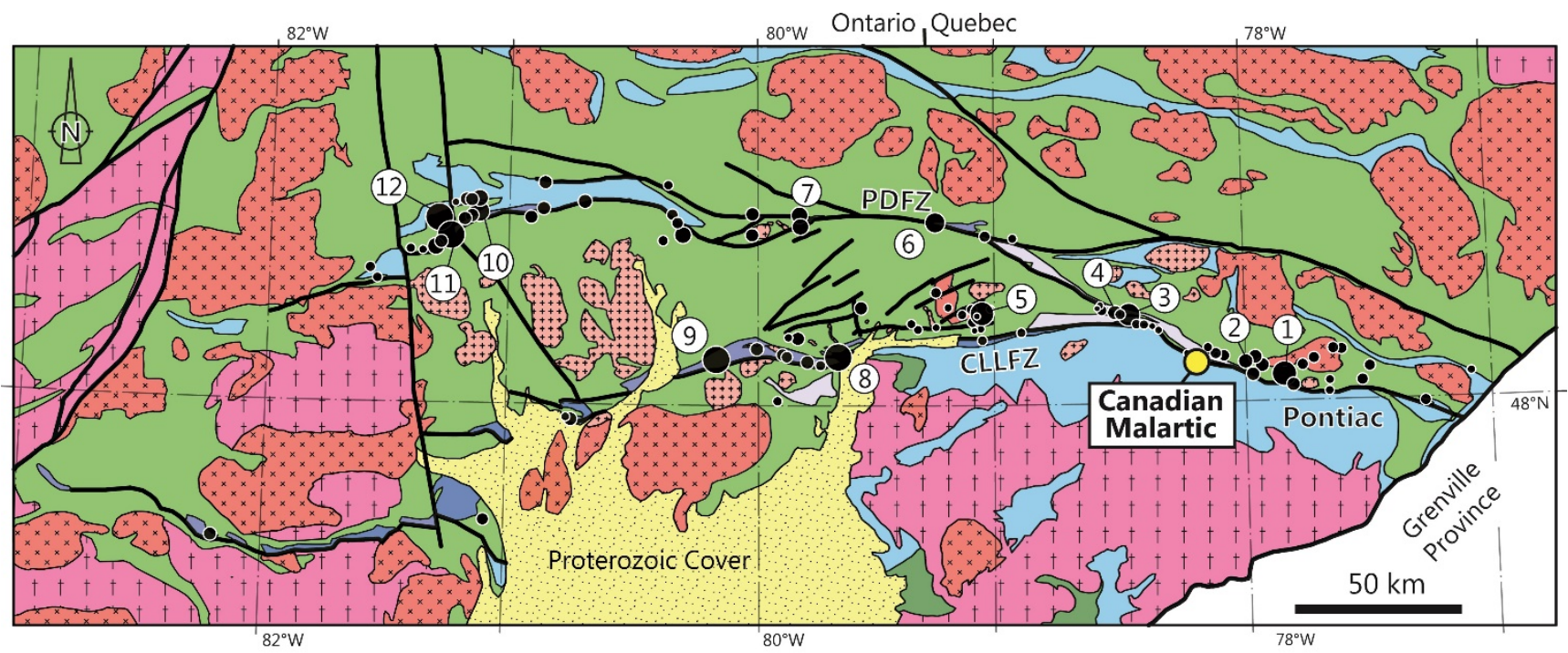

\section{Granitic units

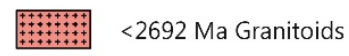

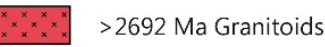 \\ $+\dagger$ Gneiss}

\section{Gold deposits}

1 Sigma-Lamaque 2 Camflo, Kiena

3 LaRonde-Penna

\section{Sedimentary units}

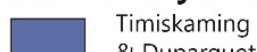

\& Duparquet

Cadillac

\& Kewagama

Porcupine \& Pontiac
4 Doyon

5 Horne

6 Beattie
7 Holloway 8 Kerr Addison 9 Kirkland Lake

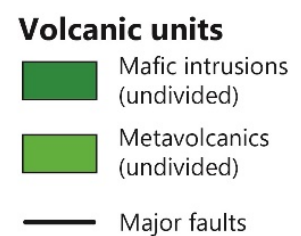

\section{Volcanic units}

Mafic intrusion

(undivided)

(undivided)

Major fault

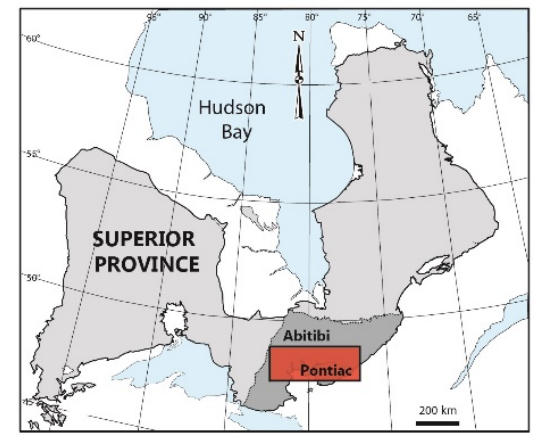

Figure 1: Geological map of the Val d'Or-Timmins gold belt displaying the major lithostratigraphic units of the southern Abitibi and Pontiac subprovinces. The Cadillac-Larder Lake Fault Zone (CLLFZ) delineates the contact between the Pontiac and Abitibi subprovinces. The Porcupine-Destor Fault Zone (PDFZ) separates the Northern (NVZ) and Southern (SVZ) volcanic zones of the Abitibi. The most significantly endowed gold deposits are preferentially distributed along these two structures. Modified from Robert et al., 2005 (Compiled from MERQOGS 1983, Robert and Poulsen, 1997, Ayer et al., 2002, Thurston et al., 2008). 


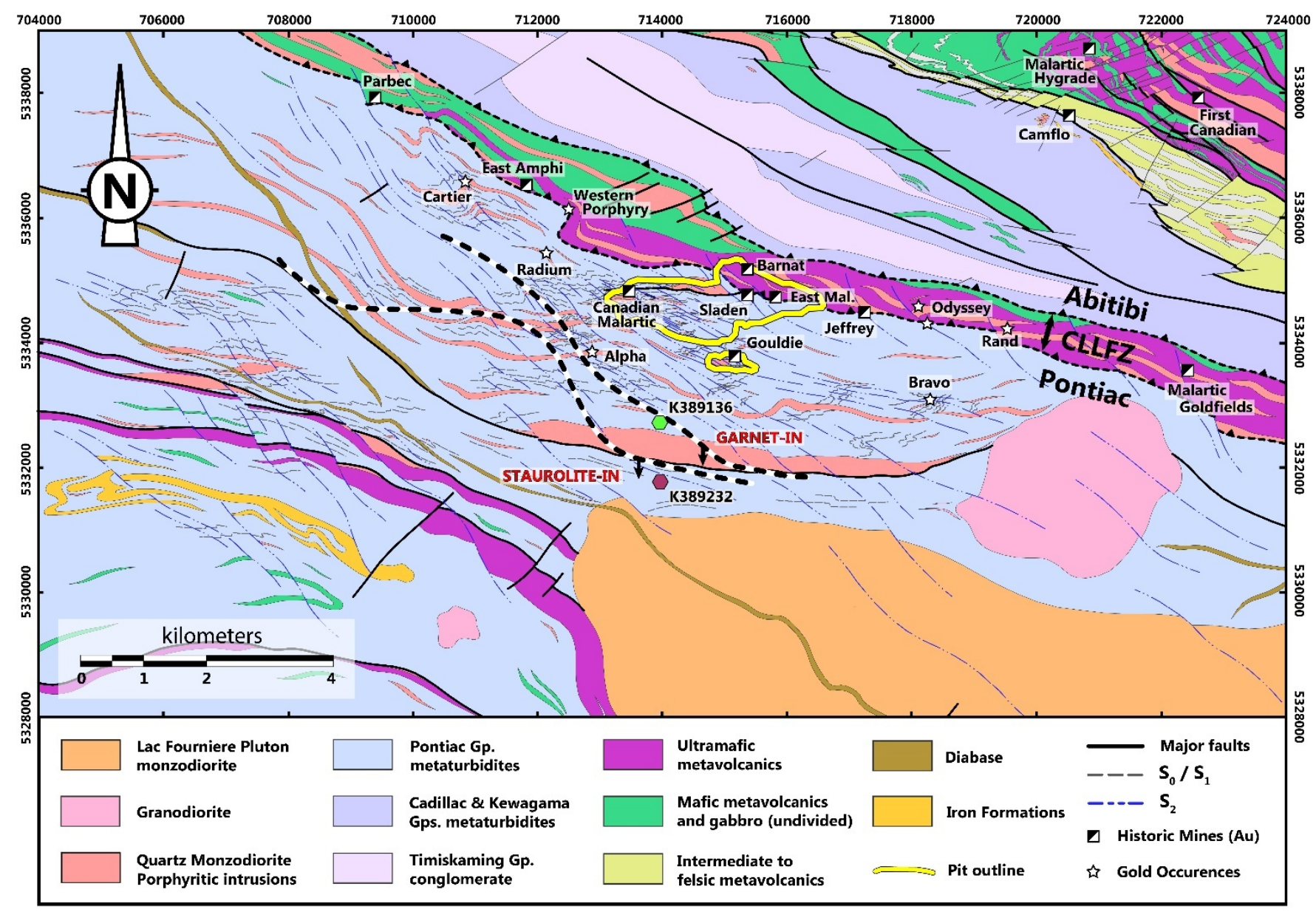

Figure 2: Geological map of the Canadian Malartic district (modified from Perrouty et al., 2017; compiled after Derry, 1939; Gunning and Ambrose, 1943; Minerais Lac Limited, unpublished reports and maps; Sansfaçon et al., 1987a,b; Fallara et al., 2000; MERNQ airborne magnetic and outcrop data, SIGEOM Database, 2016). The map displays the main metamorphic features, including garnet-and staurolite-in isograds, as well as $S_{0-1}$ and $S_{2}$ foliations. The outline of the Canadian Malartic open-pit mine is represented as a yellow line. The locations of historic gold mines and occurrences are also shown. Coordinates are in UTM (NAD83-17N). 


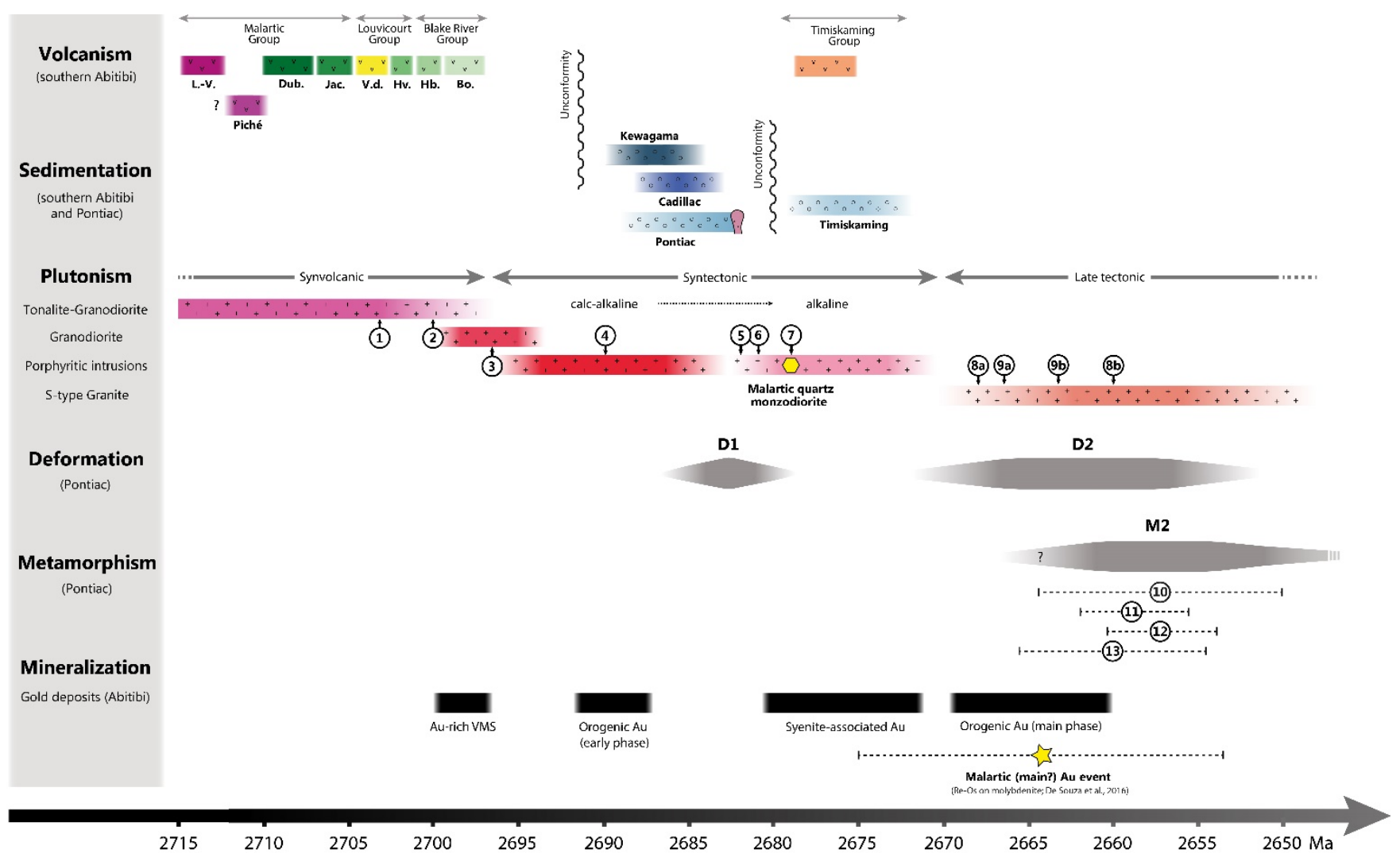

Figure 3: Chronological sequence of volcanic, sedimentary, magmatic, deformation, metamorphic and oreforming events in the Pontiac and Southern Abitibi Subprovinces (modified from Bateman et al., 2005; Robert et al., 2005; Pilote et al., 2014). General geochronological constraints are derived from Mortensen and Card, 1993; Ayer et al., 2002; Scott et al., 2002; Davis et al., 2002; Ayer et al., 2005; Frieman et al., 2017 and references therein. Numbers represent geochronological data for specific magmatic and metamorphic events, with associated errors indicated as brackets. 1: Lac Flavrian pluton (Galley and Van Breemen, 2002); 2:

Bourlamaque batholith (Wong et al., 1991); 3: Round Lake hornblende-granodiorite (Mortensen; 1993); 4: Lac Dufault pluton (Mortensen; 1993); 5: Lac Fournière pluton (Davis, 2002); 6: Lac Fréchette pluton (Mortensen and Card, 1993); 7: Canadian Malartic quartz monzodiorite (Clark et al., in prep.); 8a-b: Preissac pluton, muscovite-garnet monzogranite (Ducharme et al., 1997); 9a-b: Decelles complex, pegmatite units (Mortensen and Card, 1993); 10: Lu-Hf on garnet (Pontiac Group), Malartic area (Piette-Lauzière, 2017); 11: U-Pb on monazite, Kidd Creek mine (Davis et al., 1994); 12: ${ }^{40} \mathrm{Ar}{ }^{39} \mathrm{Ar}$ on biotite, Destor area (Powell et al., 1995); 13: U$\mathrm{Pb}$ on titanite, Lac Opasatica orthogneiss (Machado et al., 1991). Abbreviations (lithostratigraphic formations): Bo.: Bousquet; Dub.: Dubuisson; Hb.: Hébécourt; Hv.: Héva; Jac.: Jacola; L.-V.: La Motte-Vassan; V.d.: Val d'Or 

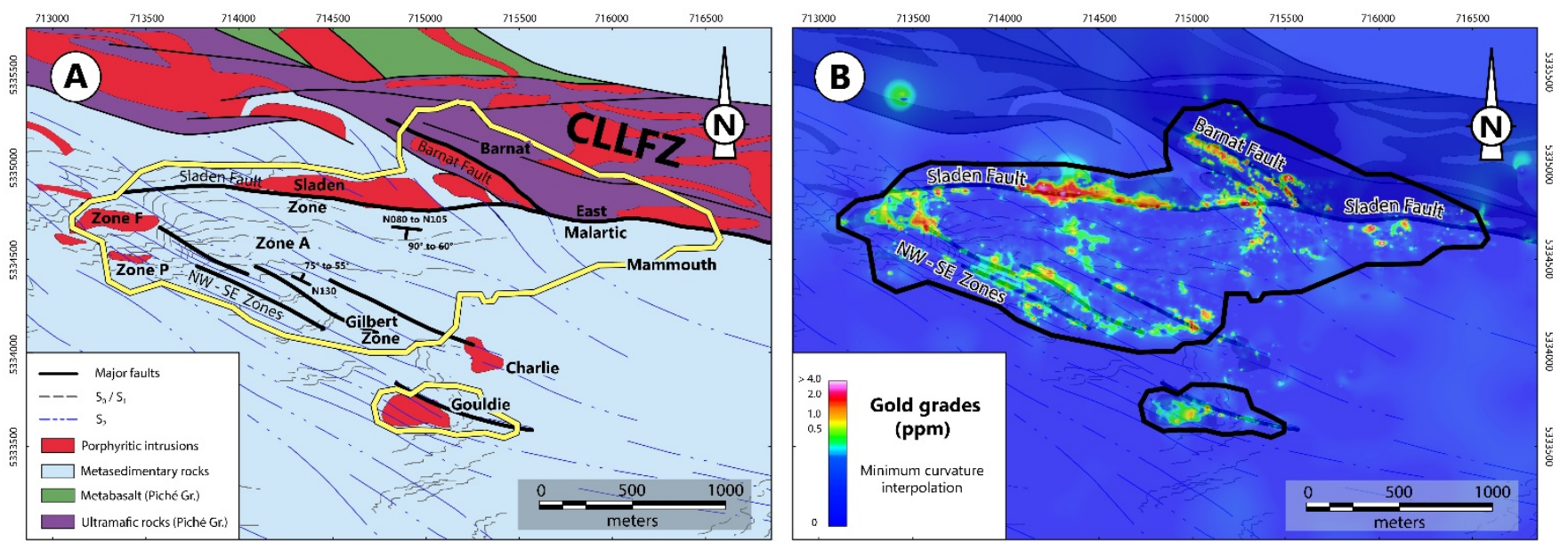

Figure 4: A. Lithological/structural map of the Canadian Malartic gold deposit (adapted from Pilote, 2014; and field mapping). The structures that acted as the main hydrothermal pathways for mineralizing fluids are highlighted as bold black lines (i.e., Sladen and Barnat Faults, NW-SE deformation zones). The trace of the sedimentary bedding $\left(S_{0-1}\right)$ and the main $S_{2}$ foliation are from Perrouty et al., 2017; B. Distribution of gold grades in the Canadian Malartic deposit (all lithologies combined). Note the close spatial association of gold mineralization with the main hydrothermal fluid pathways (interpolated from Canadian Malartic Corporation gold assay data). 

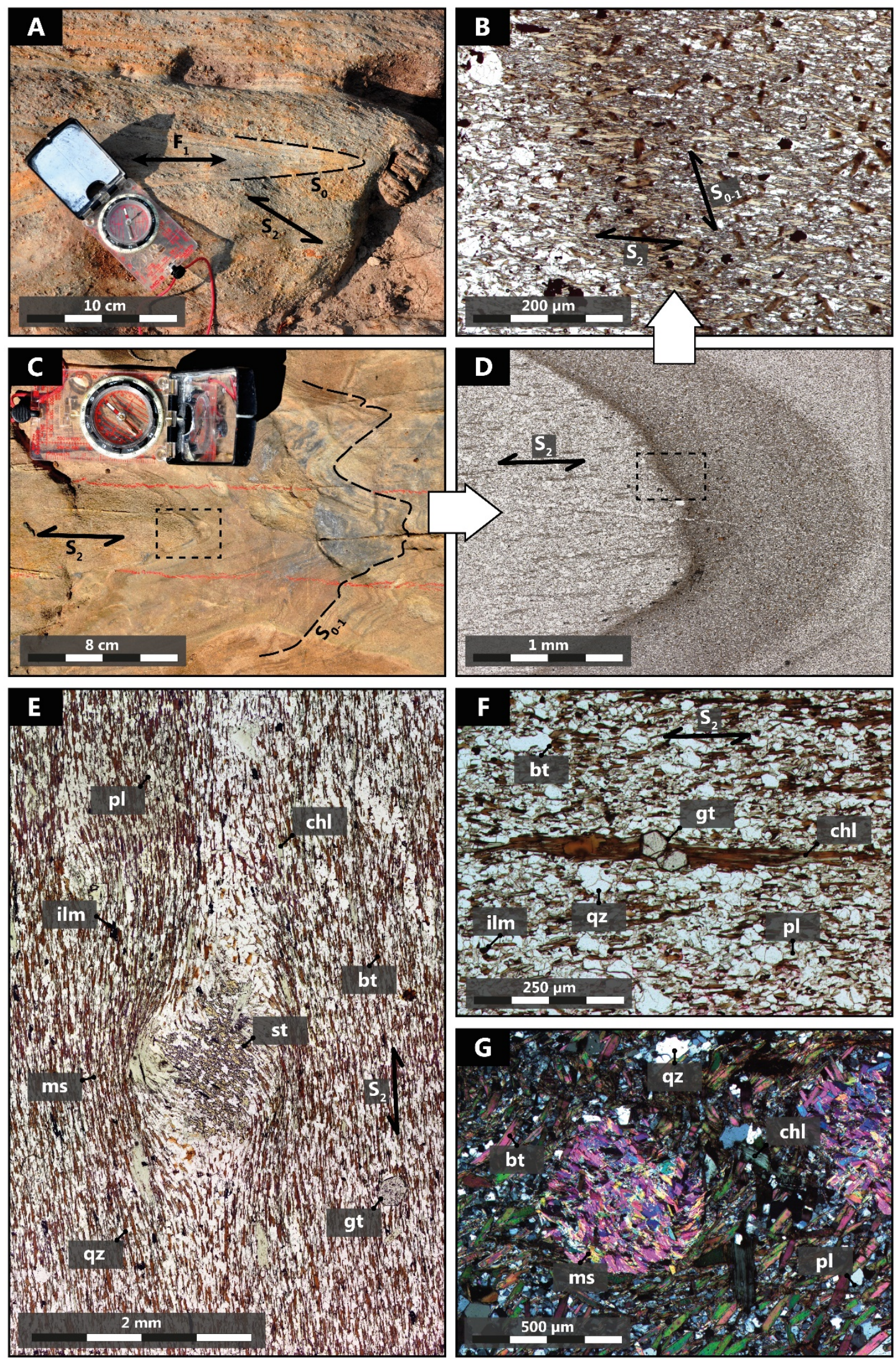
Figure 5: Metamorphic and textural characteristics of unaltered Pontiac Group metasedimentary rocks from the Malartic district. $\boldsymbol{A}$ : isoclinal $F_{1}$ fold overprinted by penetrative regional $S_{2}$ foliation; $\boldsymbol{B}-D$ : relationship between $S_{2}$ and $S_{0-1}$ fabrics in a $F_{2}$ fold hinge, from outcrop $(C)$ to thin-section $(D)$ to microscopic scale $(B)$. The $S_{1}$ foliation is a poorly-preserved fabric defined by oriented relict biotite at a high angle to the $S_{2}$ foliation; $\boldsymbol{E}$ : photomicrograph of mudstone sample K389232 (see location in Fig.2). The main fabric $\left(S_{2}\right)$ is defined by the preferential orientation of phyllosilicates (biotite, muscovite and chlorite). The peak metamorphic assemblage is representative of mid-amphibolite facies $P$-T conditions, as defined by the occurrence of staurolite and almandine garnet. Staurolite poikiloblasts record syn-kinematic rotation (interpreted as late $D_{2}$ ); $\boldsymbol{F}$ : photomicrograph of lower-amphibolite facies greywacke sample K389136 (see location in Fig.2). The $S_{2}$ foliation is defined by elongated biotite and chlorite, which together with garnet, plagioclase and ilmenite reflect the peak metamorphic assemblage; $\boldsymbol{G}$ : randomly oriented aggregates of muscovite in pseudomorphs after an unidentified prograde metamorphic mineral (cordierite?) in garnet-staurolite bearing siltstone. Mineral abbreviations: bt: biotite; chl: chlorite; gt: garnet; ilm: ilmenite; ms: muscovite; pl: plagioclase; qz: quartz; st: staurolite. 

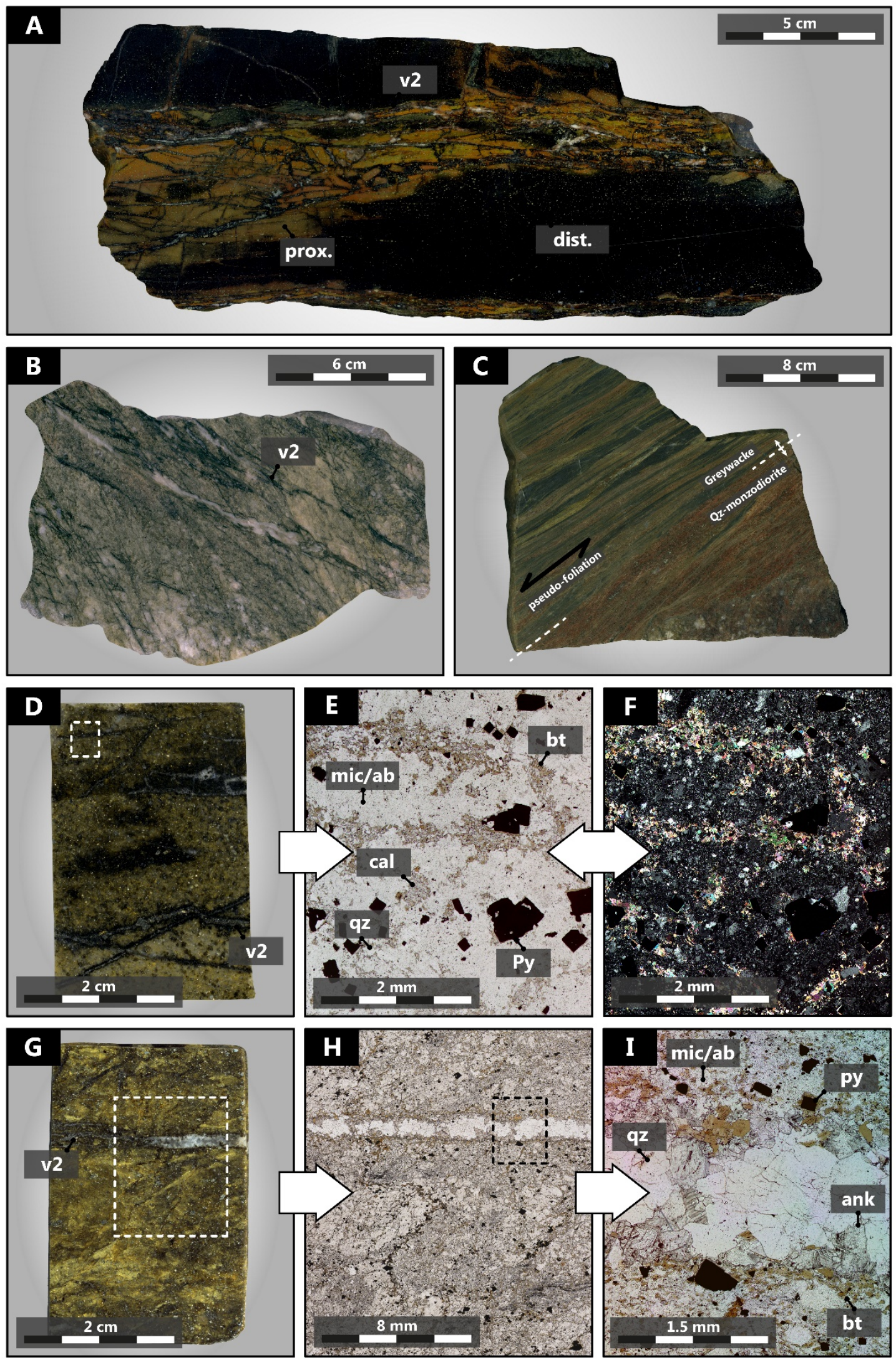
Figure 6: Representative textural and mineralogical features of the proximal alteration assemblage. A:

Hydrothermally-cemented, open-space filled stockwork breccia associated with intense ore-stage quartz-biotitecarbonate-microcline \pm pyrite (v2) veining in greywacke. Proximal yellowish/brown replacement occurs as an alteration envelope around $v 2$ veinlets, and transitions outwards to a distal alteration assemblage; B: Proximal alteration in quartz monzodiorite consists of a beige/pinkish-colored replacement assemblage that obliterates the host-rock porphyritic texture. It is associated with dense stockwork veining and occurs an alteration halo adjacent to ore-stage ( $v 2)$ veinlets; $\boldsymbol{C}$ : Innermost proximal alteration at the contact between greywacke and quartz monzodiorite porphyry (Sladen Fault zone). This facies is characterized by a mylonitic fabric (ductile deformation) associated with intense replacement-type alteration; $\boldsymbol{D}$-F: Pervasive proximal alteration in greywacke, from thin-section (D) to microscopic scale (E: plane light; F: cross-polarized light). Stringers and fracture zones of phlogopite-carbonates-quartz-pyrite-rutile (v2 stage) develop interstitially between patches of microcrystalline $(<10 \mu \mathrm{m})$ microcline-albite \pm quartz; $\boldsymbol{G}$ - I: Beige/brown replacement-type alteration in greywacke, from thin-section $(G)$ to microscopic scale (H-I, plane light). Ore-stage quartz-biotite-calcite-ankerite-microclinepyrite veinlets (v2) with narrow biotite-calcite \pm pyrite selvages. Mineral abbreviations: ab: albite; ank: ankerite; bt: biotite; cal: calcite; mic: microcline; py: pyrite; qz: quartz. 

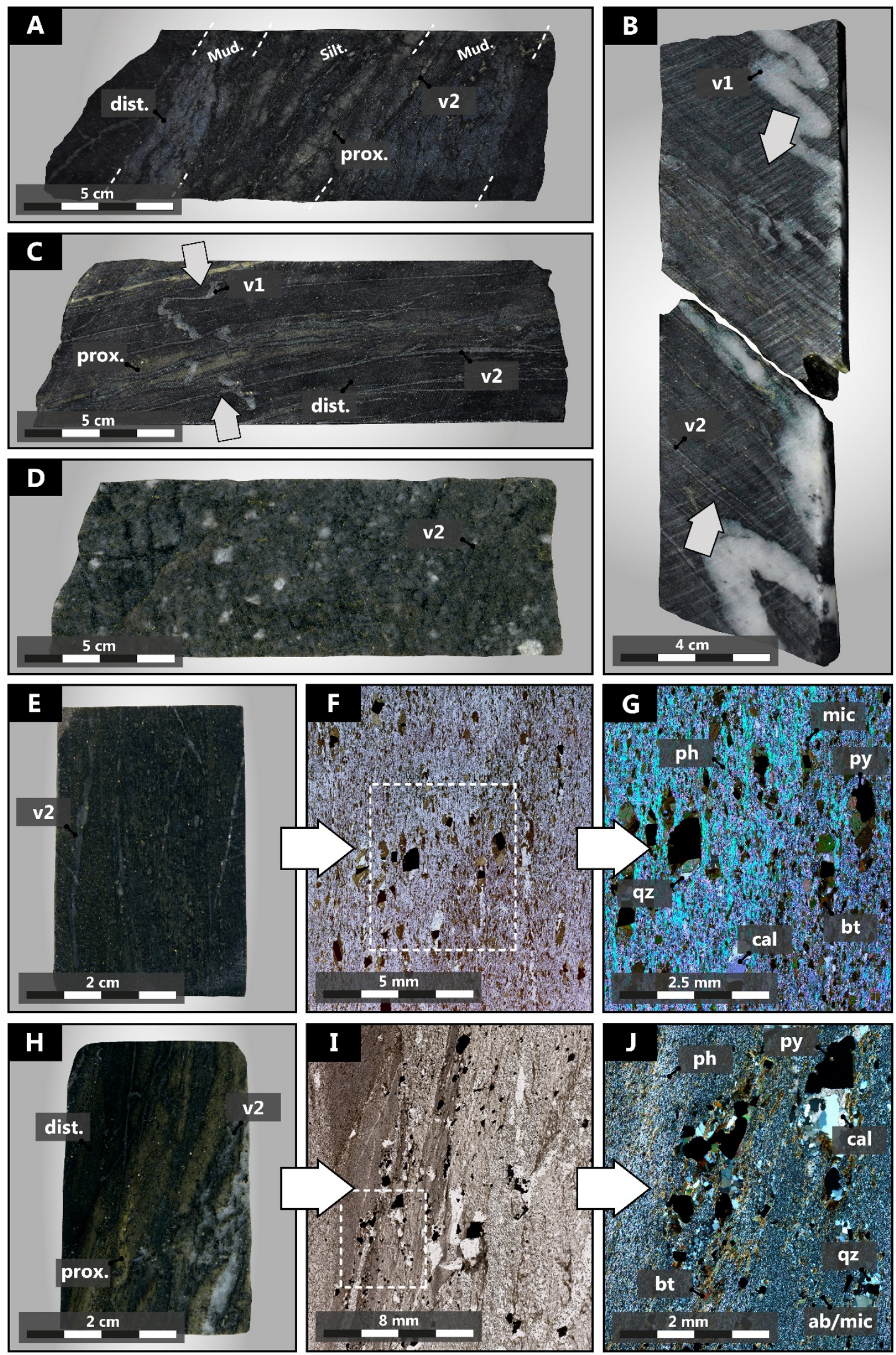
Figure 7: Representative textural and mineralogical features of the distal hydrothermal alteration assemblage. A: Quartz-biotite-carbonate-microcline \pm albite-pyrite ore-stage stockwork veining (v2) in a metasedimentary mudstone-siltstone sequence. Proximal beige (microcline/albite-dominated) replacement occurs locally as an alteration envelope around $v 2$ veinlets, and transitions outwards to a blue/grey (sericitic) distal alteration assemblage. Sericitization was preferentially developed in the fine-grained mudstone facies; $\boldsymbol{B}$ - $\boldsymbol{C}$ : Distal alteration in siltstone ( $B$ - from the Gouldie Zone) and greywacke ( $C$-from the Gilbert Zone). Main-stage stockwork veinlets (v2) and associated alteration features preferentially occur parallel to the main foliation $\left(S_{2}\right)$ and are axial planar with respect to $F_{2}$ folding (arrows represent the apparent $D_{2}$ shortening direction); $\boldsymbol{D}$ : Medium-grey distal alteration in quartz monzodiorite occurs as a network of coalesced biotite \pm chloritecarbonate-quartz-microcline-pyrite (v2) stringers interstitial to igneous feldspar phenocrysts. $\boldsymbol{E}$-G: Stockworkassociated distal alteration in siltstone, from thin-section (E) to microscopic scale (F: plane light; G: crosspolarized light). Alteration phases (including quartz, biotite, microcline and carbonates) systematically crystallize in pyrite pressure shadows, which are preferentially oriented parallel to the pseudo-foliation defined by mainstage white mica and biotite; $\boldsymbol{H}$-J: Protolith-controlled transition from proximal to distal alteration facies, from thin-section (H) to microscopic scale (I: plane light; J: cross-polarized light). Biotite forms stringers oriented orthogonally to the $D_{2}$ principal stress and crystallizes in pyrite pressure shadows. Mineral abbreviations: ab: albite; bt: biotite; cal: calcite; mic: microcline; ph: phengite; py: pyrite; qz: quartz. 

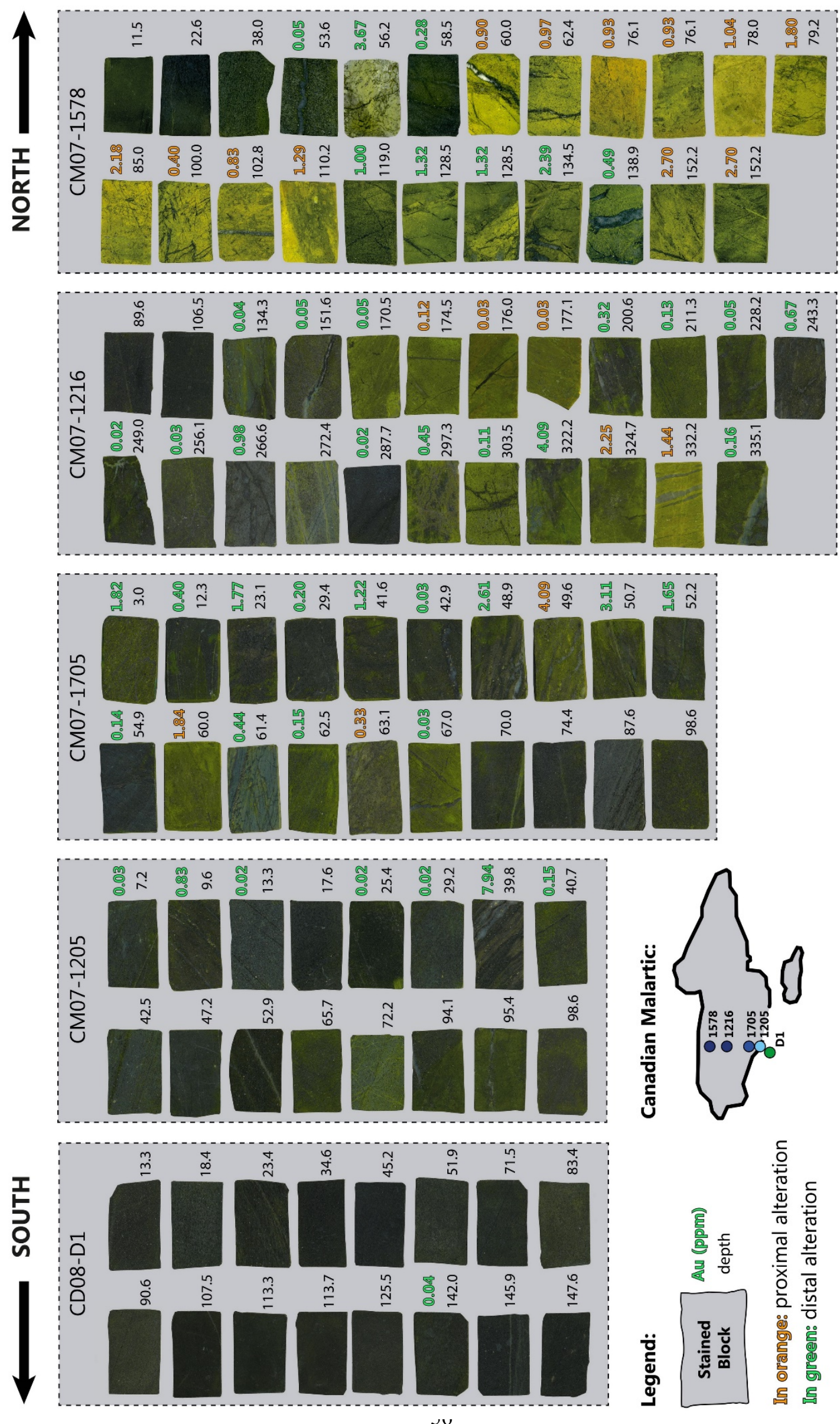
Figure 8: Thin section blocks of metasedimentary rocks (n=98) from drillholes DDH 1578, 1216, 1705, 1205 and D1 (see Fig.12A for locations) were stained using sodium cobaltrinite to identify and evaluate K-feldspar alteration (in yellow). The blocks are displayed with increasing depth down-hole. Gold grades (>20 ppb) are color-coded as a function of the alteration characteristics (proximal alteration in orange, distal alteration in green). Potassic alteration (in the form of pervasive microclinization) displays a close association with gold mineralization and intensifies with increasing proximity to the main hydrothermal fluid pathways. 

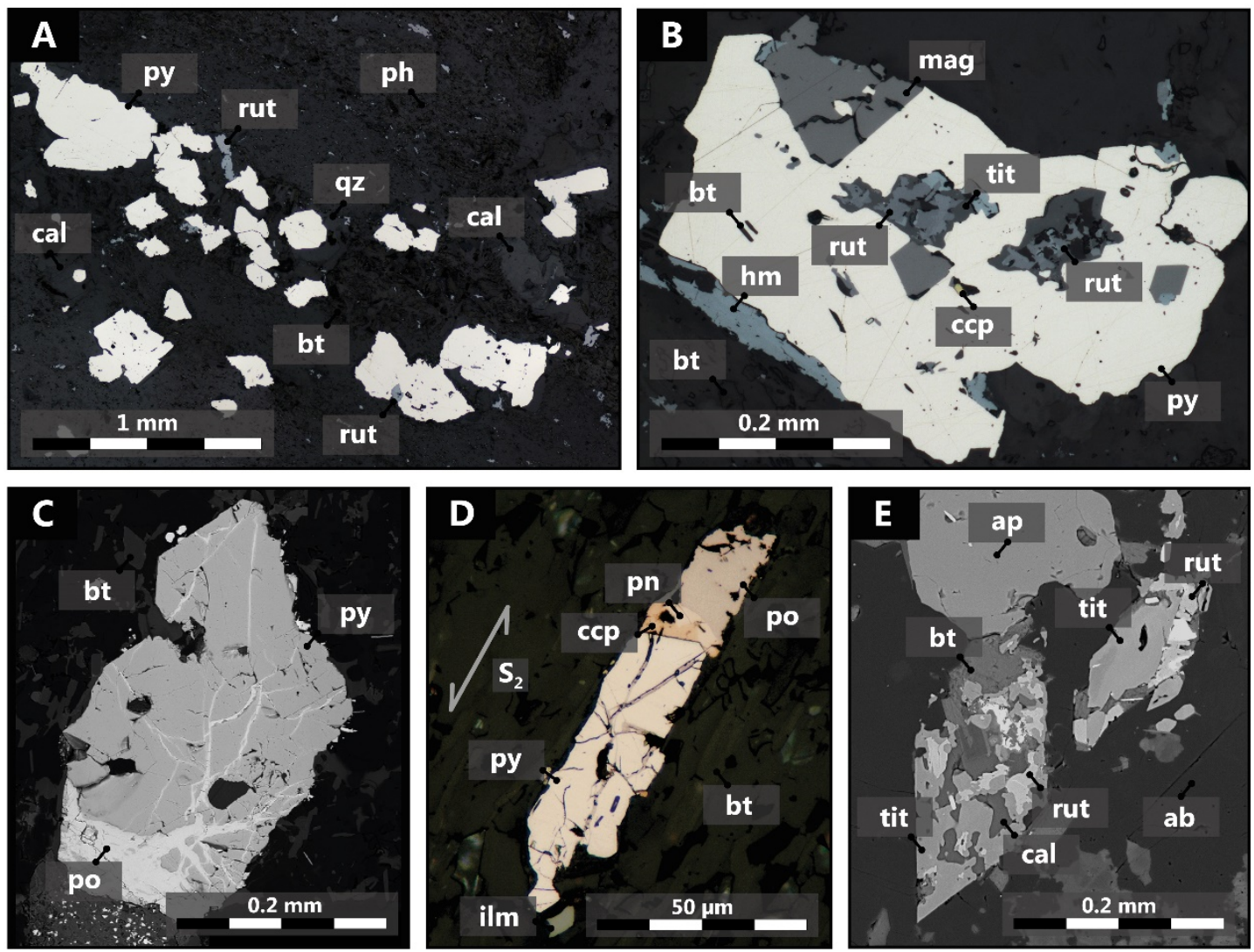

Figure 9: Representative textural relationships for sulfide-oxide associations in the Malartic district. Systematic transitions in Fe-sulfide and (Fe-Ti)-oxide mineralogy are used as a framework for monitoring changes in physico-chemical parameters (e.g., $\sum a \mathrm{~S}$ and/or $\mathrm{fO}_{2}$ ). A: Disseminated pyrite associated with rutile in distallyaltered greywacke (reflected light); B: Euhedral magnetite and titanite in igneous rocks are overgrown and partially replaced by pyrite-hematite-rutile in proximally-altered quartz monzodiorite (reflected light); $\boldsymbol{C}$ : Backscattered electron image showing partial replacement of pyrite by pyrrhotite in greywacke beyond the oreshell. This texture is interpreted to reflect the breakdown of pyrite to pyrrhotite during prograde metamorphism; D: Elongated pyrite grain in mudstone outside the alteration zone marks the main $S_{2}$ foliation and is replaced/overgrown by pyrrhotite-chalcopyrite-pentlandite (reflected light); $\boldsymbol{E}$ : Backscattered image of primary titanite partially replaced by rutile-calcite \pm (biotite-pyrite) in altered quartz monzodiorite. Mineral abbreviations: ab: albite; ap: apatite; bt: biotite; cal: calcite; ccp: chalcopyrite; hm: hematite; mag: magnetite; mic: microcline; ph: phengite; pn: pentlandite; po: pyrrhotite; py: pyrite; qz: quartz; rut: rutile; tit: titanite. 

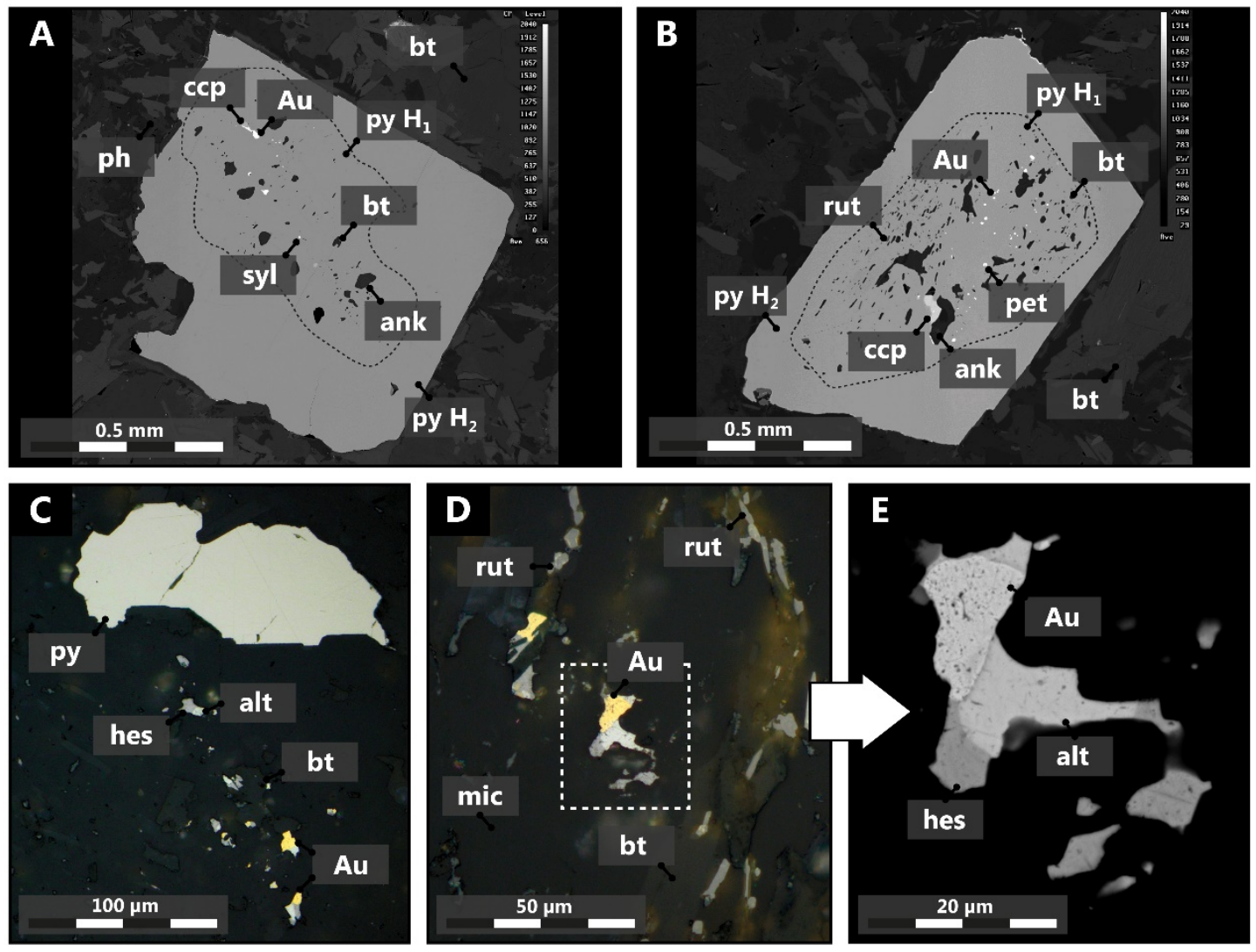

Figure 10: Representative ore textures from the Canadian Malartic deposit. A-B: Backscattered electron images of zoned subhedral pyrite grains, which consist of an inclusion-rich core $\left(H_{1}\right)$ overgrown by an inclusion-free rim ( $\left.\mathrm{H}_{2}\right)$. Inclusions of native gold and $\mathrm{Au}$-(Ag-Pb)-bearing tellurides (petzite, sylvanite, calaverite), as well as biotite and ankerite are restricted to the pyrite core; $\mathrm{C}$ : Photomicrograph (reflected light) of native gold and (Ag-Pb)bearing tellurides, in close proximity to pyrite; D: Photomicrograph (reflected light) of native gold and tellurides (hessite and altaite) within silicates (microcline and biotite), adjacent to rutile (yellow internal reflections) ; $\boldsymbol{E}$ : Backscattered electron image (inset from D) detailing the textures of native gold, hessite and altaite. Mineral abbreviations: alt: altaite; ank: ankerite; Au: gold; bt: biotite; ccp: chalcopyrite; hes: hessite; pet: petzite; mic: microcline; ph: phengite; py: pyrite; rut: rutile; syl: sylvanite. 

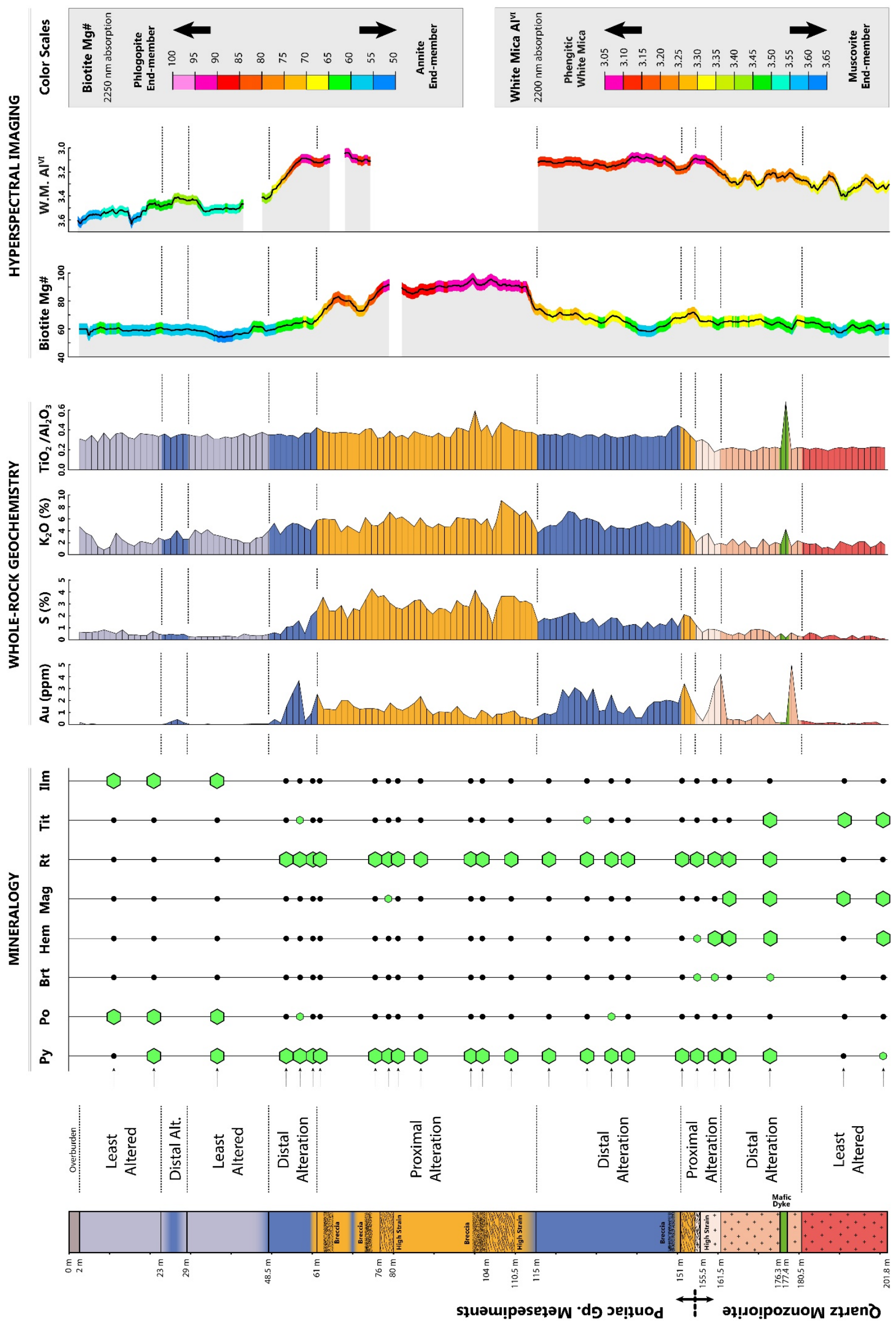
Figure 11: Mineralogical, geochemical and hyperspectral variations down DDH-1578 (see location in Fig. 12A) typify the zonation of alteration adjacent to the Sladen Fault. Hydrothermally-altered metasedimentary rocks contain pyrite and rutile as the main Fe-sulfide and (Fe-Ti)-oxide phases. In contrast, metasedimentary rocks beyond the alteration zone are characterized by a pyrite-pyrrhotite-ilmenite assemblage. Hydrothermal alteration associated with gold mineralization is characterized by increasing concentrations of $\mathrm{S}$ and $\mathrm{K}_{2} \mathrm{O}$ from unaltered metasedimentary rocks through distal to proximal alteration zones, which coincide spatially with changes in oxide-sulfide mineralogy. The $\mathrm{TiO}_{2} / \mathrm{Al}_{2} \mathrm{O}_{3}$ ratio of immobile elements was used to discriminate between the different host-rock lithologies. Mineralogical and geochemical variations are correlated with changes in biotite $M g \#$ and white mica $A l^{V I}$ content. The hyperspectral profiles emphasize the zonal distribution of alteration, which is evident in the systematic increase in biotite $\mathrm{Mg \#}\left[\mathrm{molar} \mathrm{Mg} /\left(\mathrm{Fe}_{\text {total }}+\mathrm{Mg}\right)\right](2250 \mathrm{~nm}$ absorption) and in the phengitic component of white mica (2250 $\mathrm{nm}$ absorption) towards hydrothermal fluid pathways (decrease in Al ${ }^{V I}$ content). The width of the color bar represents the standard error associated with the regression. The oxidesulfide mineralogy was determined through thin section optical microscopy and scanning electron analysis. Concentrations of $\mathrm{Al}_{2} \mathrm{O}_{3}, \mathrm{TiO}_{2}, \mathrm{~K}_{2} \mathrm{O}$ and $\mathrm{S}$ were measured by $\mathrm{pXRF}$ analysis at the Memorial University of Newfoundland (analytical procedure as in Piercey and Devine, 2014) and cross-calibrated using whole-rock analyses determined from conventional methods. Mineral abbreviations: brt: barite; hem: hematite; ilm: ilmenite; mag: magnetite; po: pyrrhotite; py: pyrite; rut: rutile; tit: titanite. 

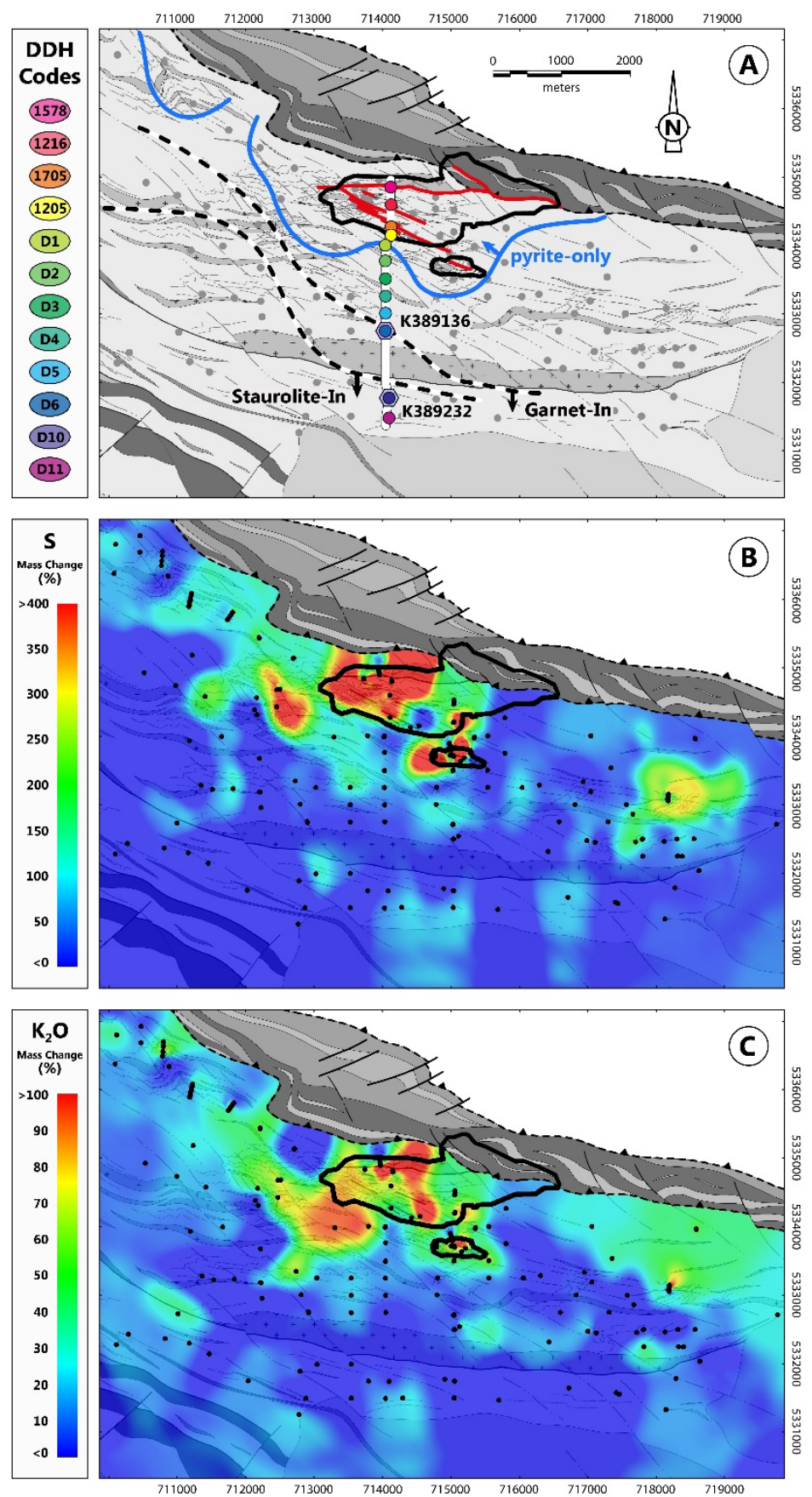

Figure 12. A: Lithological/structural map (A) of the Canadian Malartic gold district (adapted from Perrouty et al., 2017). Samples investigated for mica mineral chemistry were collected from a series of drillholes (represented as colored circles) that define $a \sim 3.5 \mathrm{~km}$ north-south cross-section $\left(P_{2}\right)$ extending from the ore shell towards the Lac Fournière pluton to the south. The extent of the hydrothermal sulfidation/oxidation halo in metasedimentary rocks is outlined by the outermost distribution of pyriteonly (as the only Fe-sulfide) samples (see text). The blue line delineates an envelope that contains $<50 \%$ of the investigated surficial samples (grey dots), but includes $>75 \%$ of the pyrite-only samples; $\boldsymbol{B}-\boldsymbol{C}$ : Maps illustrating sulfur (B) and potassium (C) mass changes in metasedimentary rocks from the Canadian Malartic district (in \%, relative to least altered rocks). A lithogeochemical zoning with respect to gold mineralization is evident from increasing $\mathrm{S}$ and $\mathrm{K}_{2} \mathrm{O}$ mass gains towards the deposit. 

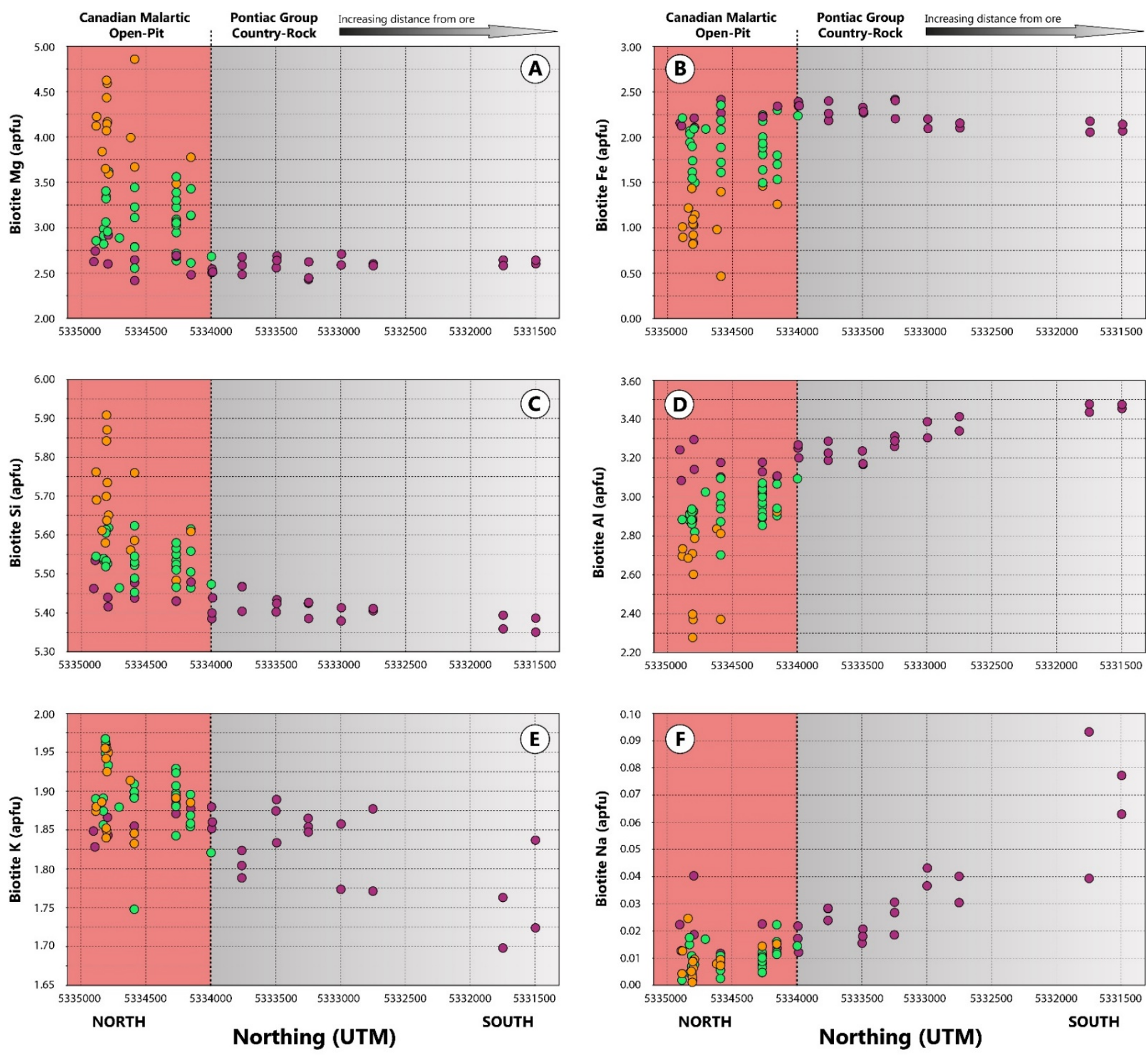

Proximal potassic alteration

Distal potassic-sericitic alteration

Non-mineralized, least-altered Pontiac country-rock 
Figure 13: Average biotite composition (atoms per formula unit) in Pontiac Group metasedimentary rocks as a function of distance from the Canadian Malartic ore zone (pink-colored) along the north-south $\mathrm{P}_{2}$ section (see map in Fig.12A). A total of 78 samples were investigated and segregated into three categories according to alteration characteristics, from least altered (purple), through distally-altered (green) to proximally-altered metasedimentary rocks (orange). Biotite from the proximal and distal alteration zones has higher Mg and lower Fe concentrations than metamorphic biotite beyond the ore-shell (A and $\boldsymbol{B}$, respectively). There is a broad decrease in biotite $\mathrm{Si}(\boldsymbol{C})$ and $\mathrm{Fe}+\mathrm{Mg}$ contents, matched by a progressive increase in $\mathrm{Al}(\boldsymbol{D})$ with increasing distance southwards (towards higher metamorphic grade). Compositional variations in the interlayer site consist of a general decrease in the $K$ content $(\boldsymbol{E})$, coincident with a progressive increase in $N a(\boldsymbol{F})$ along the north-south $P_{2}$ section southwards. 

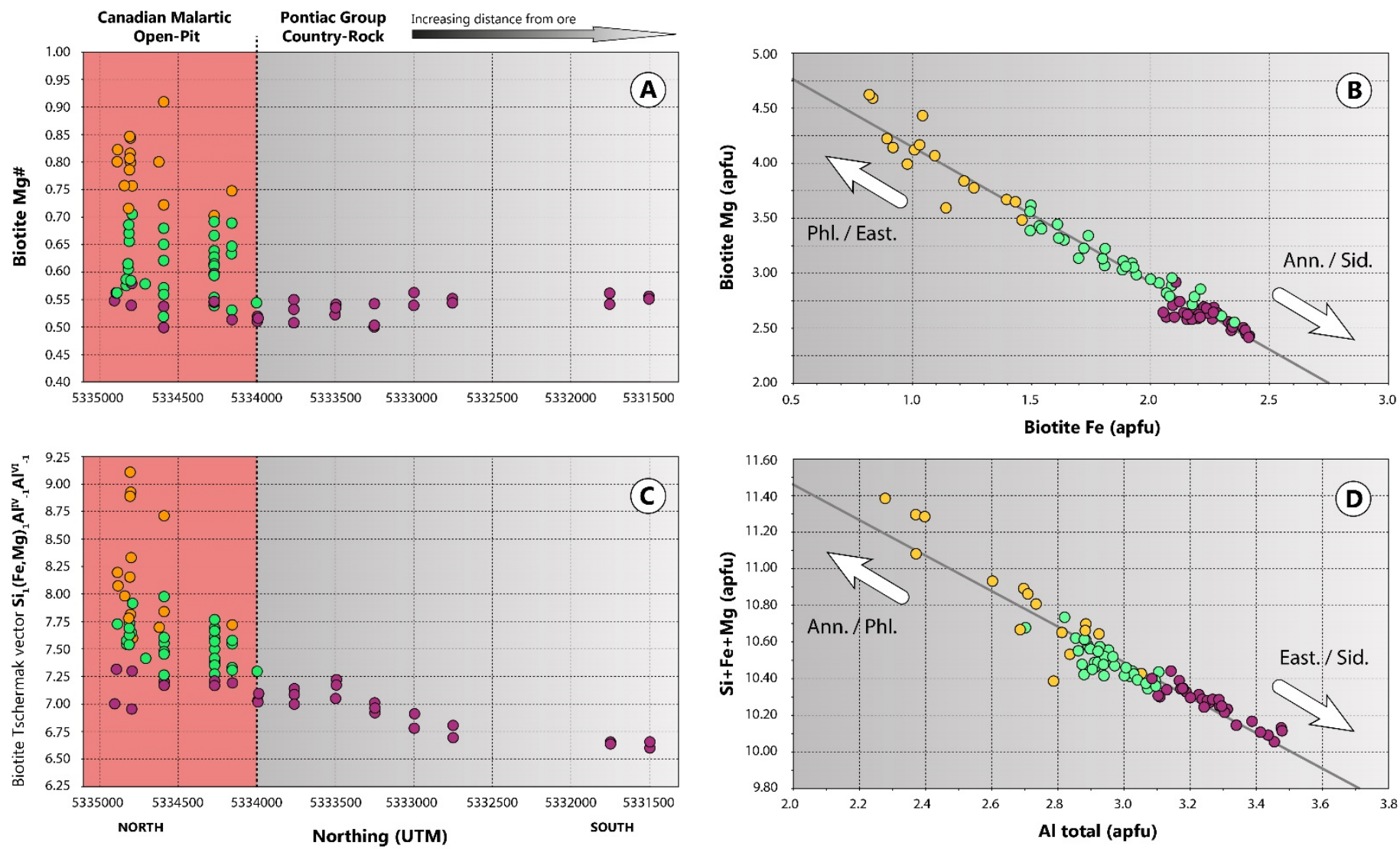

Figure 14: Compositional variations of biotite ( $\mathrm{Fe}-\mathrm{Mg}$ and Tschermak exchanges) in Pontiac Group metasedimentary rocks as a function of distance from the Canadian Malartic deposit (pink-colored) along the $P_{2}$ section (see map in Fig. 12A). Alteration characteristics are indicated from least altered (purple), to distally altered (green) and proximally altered metasedimentary rocks (orange). A: Biotite is phlogopitic within the proximal alteration zone $(0.72<M g \#<0.92)$ and is also enriched in $M g$ relative to Fe in the distal alteration zone $(0.52<M g \#<0.72)$. By contrast, metamorphic biotite consistently has intermediate $\mathrm{Mg \#}$ compositions $(0.45<M g \#<0.58)$, which display a weak trend increasing southwards. B: A linear distribution and near-unity negative slope of $-0.79\left(r^{2}=0.97\right)$ for Fe versus $\mathrm{Mg}$ indicates that variations in the biotite $\mathrm{Mg \#}$ are due mainly to the substitution $\mathrm{Fe}^{2+} \Leftrightarrow \mathrm{Mg}$ (annite-phlogopite solid solution). C: Hydrothermal alteration is reflected by a decrease in biotite Al content away from the siderophyllite-eastonite join, associated with an increase in Si and $\mathrm{Fe}+\mathrm{Mg}$. Metamorphic biotite beyond the ore zone displays a progressive decrease in the extent of Tschermak exchange (towards more aluminous compositions) with increasing distance southwards (corresponding with increasing metamorphic grade). D: Correlation $\left(r^{2}=0.90\right)$ and near-unity negative slope $(m=-0.97)$ for $(\mathrm{Fe}+\mathrm{Mg}+\mathrm{Si})$ vs. total Al indicates that variations in biotite $\mathrm{Al}$, Si and $\mathrm{Fe}+\mathrm{Mg}$ concentrations are mainly controlled by Tschermak substitution [Si ${ }_{1}\left(\mathrm{Fe}, \mathrm{Mg}{ }_{1} \mathrm{Al}^{I V}{ }_{-1} \mathrm{Al}^{V I}{ }_{-1}\right]$. Mineral abbreviations: Ann.: annite; East.: Eastonite; Phl.: phlogopite; Sid.: siderophyllite. 

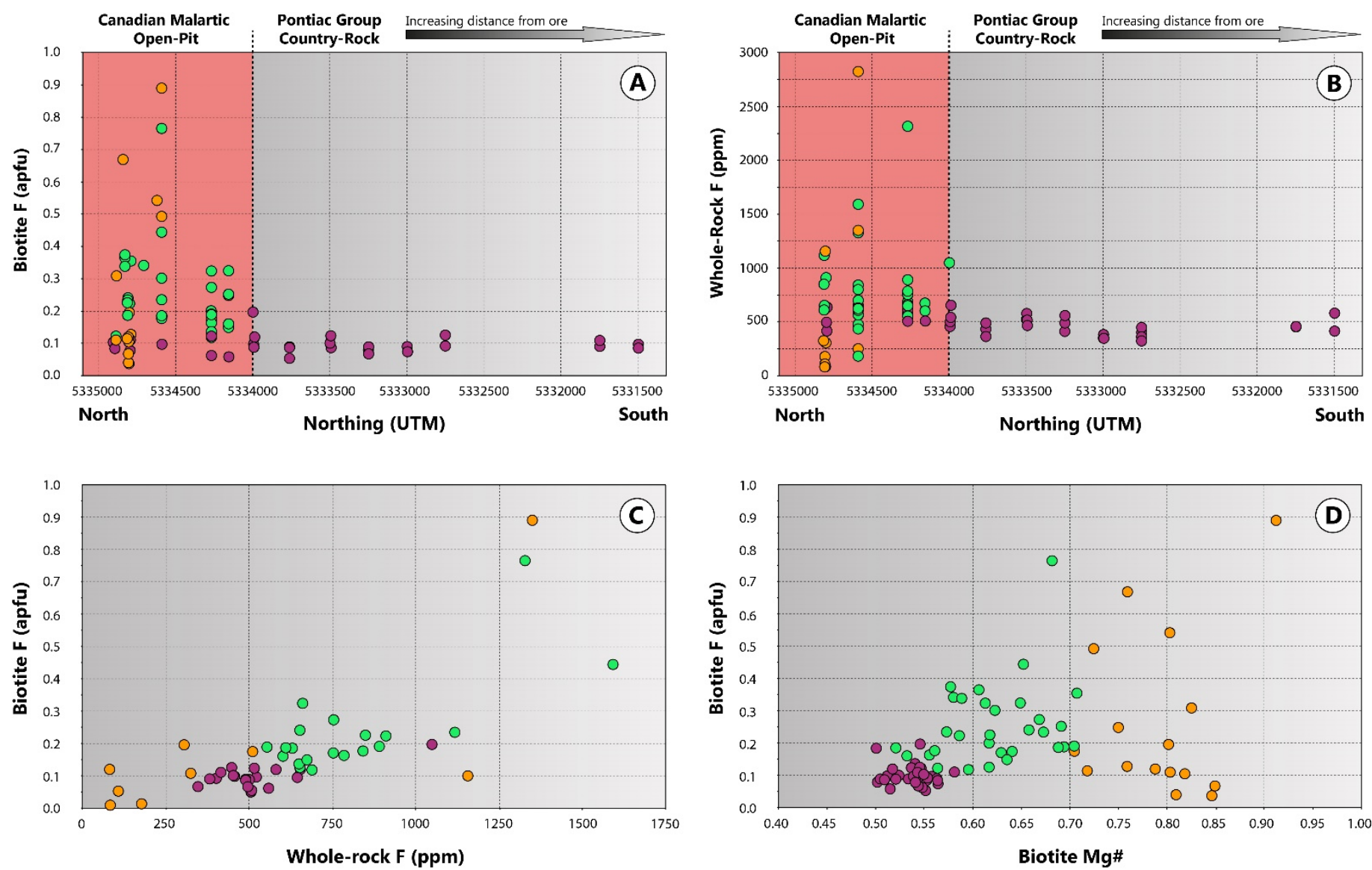

Figure 15: Variations of biotite and whole-rock fluorine compositions in Pontiac Group metasedimentary rocks. Samples were segregated into three categories according to their alteration characteristics, from least altered (purple), through distally altered (green) to proximally altered (orange) metasedimentary rocks A: The fluorine concentration of biotite outside the ore zone is generally low (0.05-0.20 apfu) and is nearly three times higher in the distal (0.12-0.77 apfu), and proximal (0.04-0.89 apfu) alteration zones. The latter is characterized by a greater degree of scattering due to unusually low fluorine contents for proximally-altered samples from the DDH1578 drill-hole (see location in Fig. 12A). B: Whole-rock fluorine composition $(n=79)$ as a function of distance along the $P_{2}$ section. Unaltered metasedimentary rocks are characterized by low fluorine contents, ranging between 300 and $750 \mathrm{ppm}$ (mean $=485 \mathrm{ppm} ; n=34$ ). Distal alteration in the metasedimentary rocks was associated with significant increases in fluorine content (325-2350 ppm; mean $=809 \mathrm{ppm})$. Fluorine in the proximal alteration zone is highly variable, ranging from 84 to $2825 \mathrm{ppm}$ (mean=733 ppm; $n=9$ ). C: Average fluorine in biotite (in apfu) as a function of whole-rock fluorine concentration (in ppm). A broad covariation between these variables suggests that incorporation of fluorine in biotite was an important factor controlling the whole-rock fluorine budget. D: Average fluorine concentration (in apfu) against Mg\# in biotite showing a broad covariation that is consistent with the crystal-chemical Fe-F avoidance principle. 


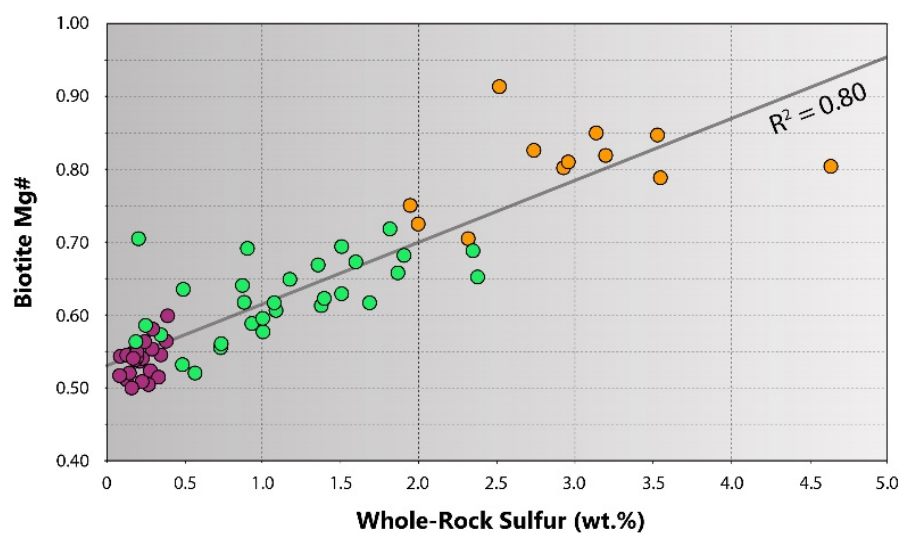

Figure 16: Average $\mathrm{Mg \#}$ in biotite as a function of whole-rock sulfur concentration (a proxy for hostrock pyritization) in Pontiac Group metasedimentary rocks. A strong positive linear relationship between these variables $\left(r^{2}=0.80\right)$ indicates that increasing sulfur metasomatism towards hydrothermal fluid pathways was associated with progressively more magnesian biotite compositions. Alteration characteristics are indicated for least altered (purple), distally altered (green) and proximally altered (orange) metasedimentary rocks. 

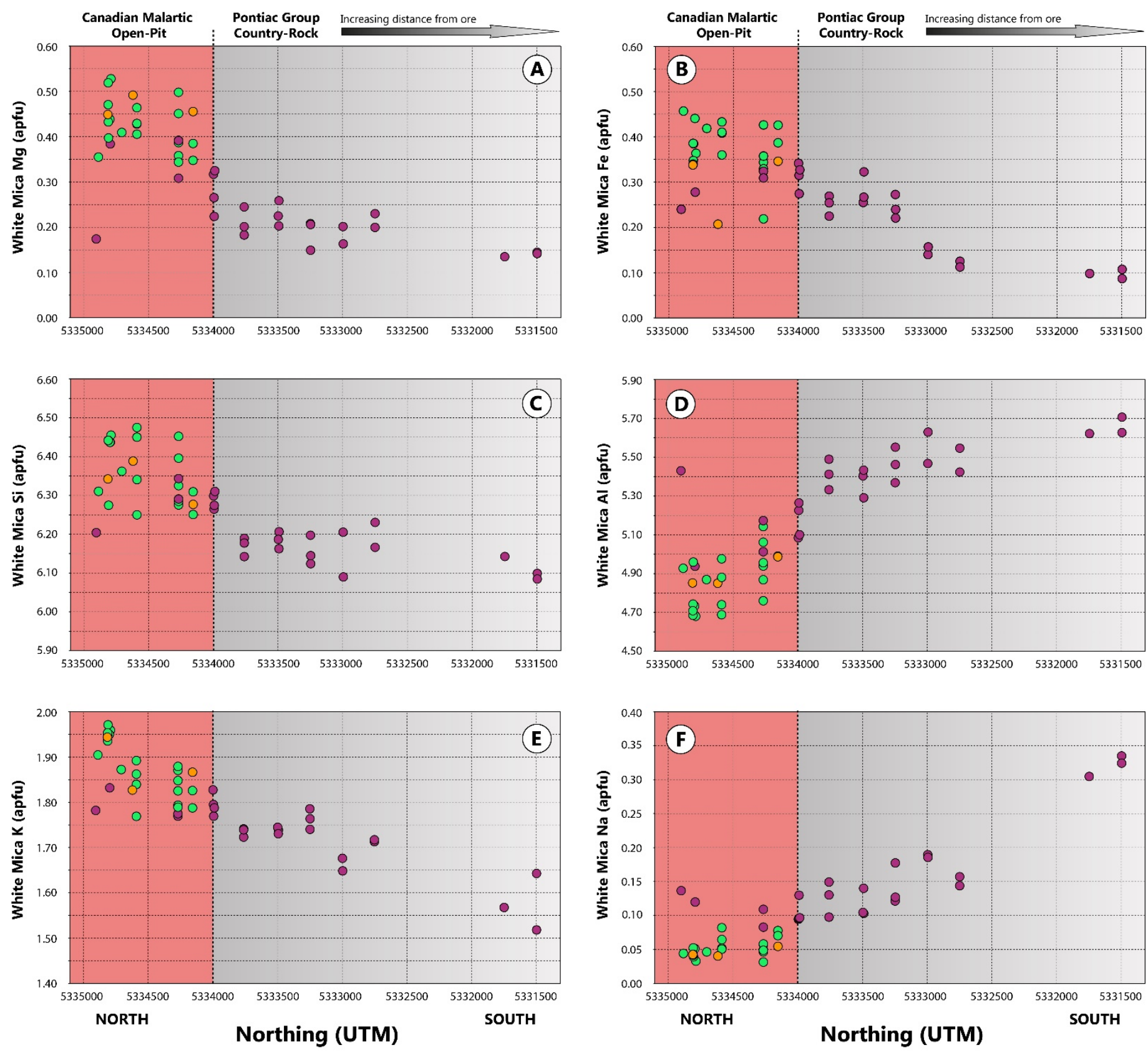

Proximal potassic alteration

$\bigcirc$ Distal potassic-sericitic alteration

Non-mineralized, least-altered Pontiac country-rock 
Figure 17: Average white mica composition (atoms per formula unit) in Pontiac Group metasedimentary rocks as a function of distance from the Canadian Malartic deposit (pink-colored) along the north-south $P_{2}$ section (see map in Fig.12A). A total of 47 samples were investigated and segregated into three categories according to their alteration characteristics, from least altered (purple), through distally altered (green) to proximally altered (orange) metasedimentary rocks. White mica from the proximal and distal alteration zones has higher Mg, Fe and Si concentrations (phengitic muscovite) than white mica beyond the ore-shell (A and $\boldsymbol{B}$, respectively). There is a steady trend toward end-member muscovite composition southwards, indicated by a progressive increase in Al (D) and decreases in $\mathrm{Si}(\boldsymbol{C})$ and $\mathrm{Fe}+\mathrm{Mg}$. The interlayer site composition is strongly correlated with increasing distance away from the deposit; there is a general decrease in K concentration southwards $(\boldsymbol{E})$, coincident with an increase in $\mathrm{Na}(\boldsymbol{F})$. 

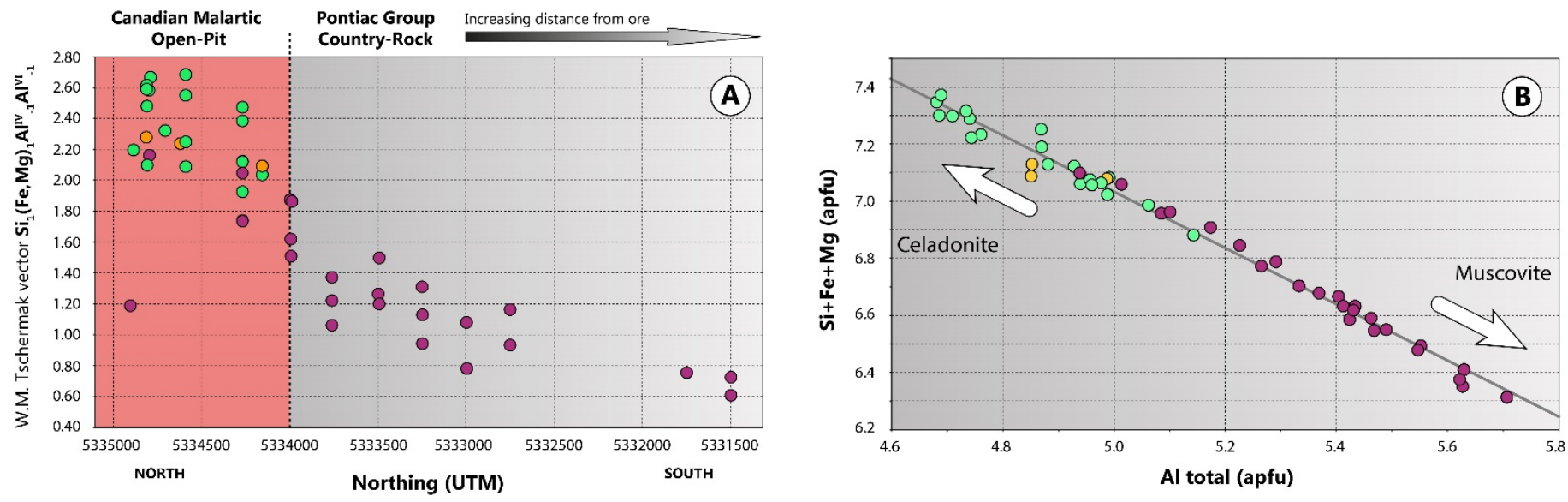

Figure 18: A: Compositional variation of white mica (Tschermak exchange, in atoms per formula unit) in Pontiac Group metasedimentary rocks as a function of distance from the Canadian Malartic ore zone (pink-colored) along the north-south $P_{2}$ section (see location in Fig.12A). The alteration color code is the same as in Fig. 13. B: A linear distribution and near-unity negative slope of $-0.99\left(r^{2}=0.99\right)$ for $(F e+M g+S i) v$. total Al indicate that variations in white mica $\mathrm{Al}$, Si and $\mathrm{Fe}+\mathrm{Mg}$ are mainly controlled by Tschermak substitution $\left[\mathrm{Si}_{1}(\mathrm{Fe}, \mathrm{Mg})_{1} \mathrm{Al} \mathrm{l}^{\mathrm{V}}\right.$. $\left.{ }_{1} \mathrm{Al}^{\mathrm{VI}}{ }_{-1}\right]$. Hydrothermal alteration is associated with a decrease in Al content, and an increase in $\mathrm{Si}$ and $\mathrm{Fe}+\mathrm{Mg}$ (towards phengite). There is a decrease in the extent of the Tschermak exchange in metamorphic white mica beyond the ore-shell (towards the muscovite end-member) with increasing distance southwards (corresponding with an increase in metamorphic grade). 

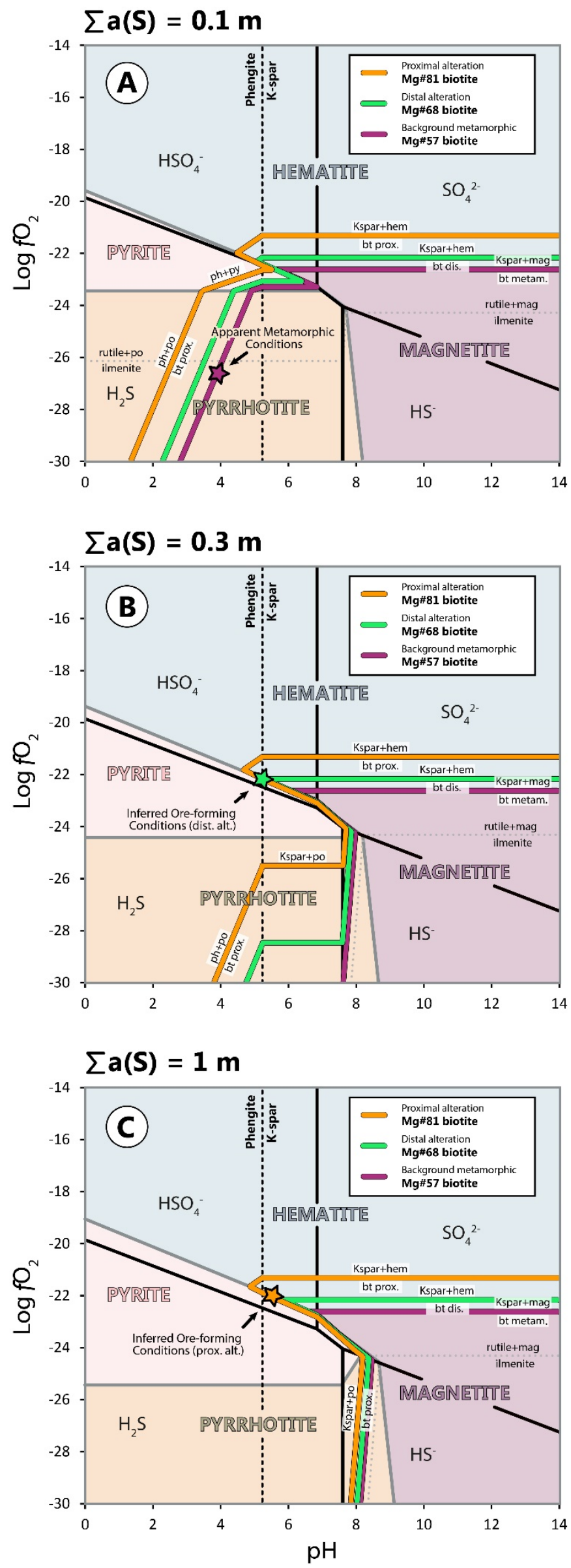

Figure 19: $\log \left(\mathrm{fO}_{2}\right)$-pH diagrams illustrating silicateoxide-sulfide equilibria under increasing total activities of sulfur species $\left(\sum a S=0.1 ; 0.3\right.$; and $\left.1 \mathrm{~m}\right)$ at the inferred conditions of ore formation $\left(475^{\circ} \mathrm{C}\right.$ and $3 \mathrm{kbar}$; Helt et al. 2014). The activity of potassium $\left(a K^{+}\right)$was fixed at $0.08 \mathrm{~m}$ (op. cit.). The activity of the annite component in biotite was determined for characteristic compositions of metamorphic biotite in metasedimentary rocks outside the ore shell and of hydrothermal biotite in the distal and proximal alteration zones (see text for calculation details). Corresponding iso-reaction contours (phase boundaries) for specific biotite compositions are represented using the same colour-code as in Fig. 13. Inferred physico-chemical conditions are schematically symbolized as stars for the non-altered metamorphic assemblage (purple), and for the distal (green) and proximal (orange) alteration zones. 


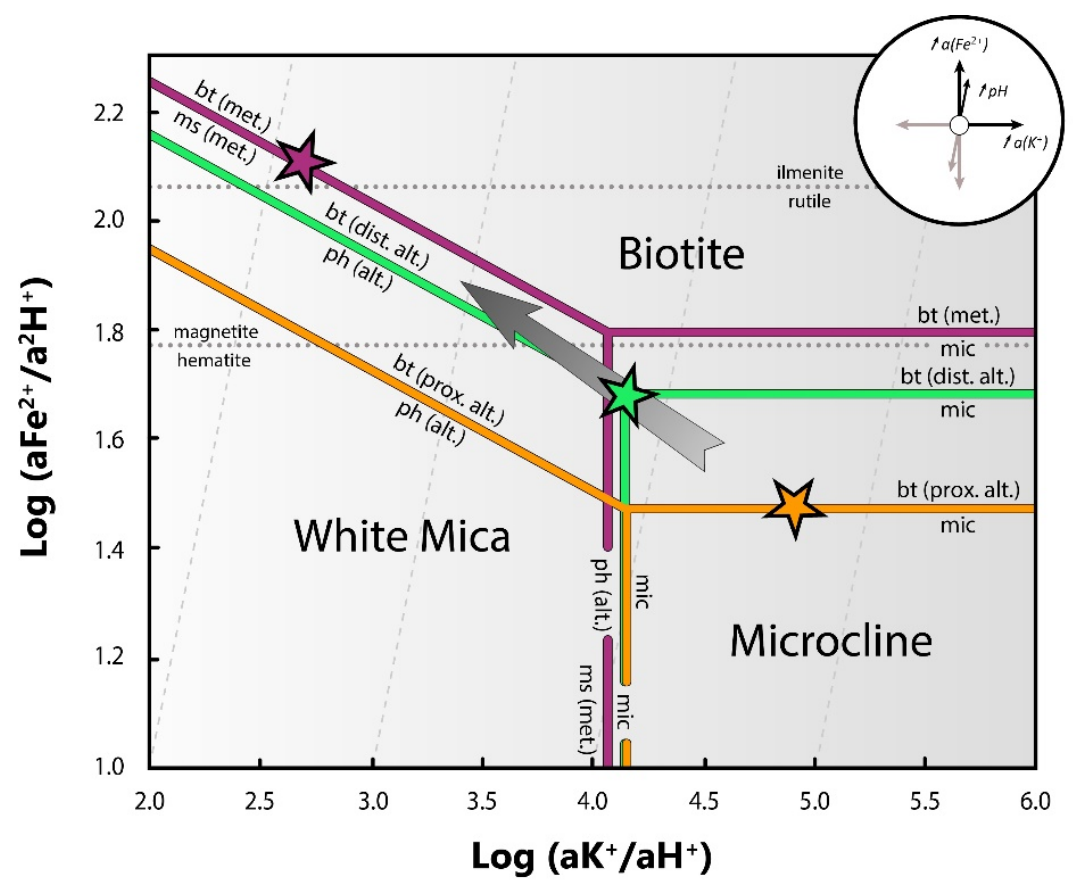

Figure 20: $\log \left(a \mathrm{Fe}^{2+} / \mathrm{a}^{2} \mathrm{H}^{+}\right)$vs. $\log \left(a \mathrm{~K}^{+} / a H^{+}\right)$diagram showing stability relationships between hydrothermal alteration $K$-silicates (biotite, white mica and microcline) in greywacke at the estimated conditions of ore formation $\left(475^{\circ} \mathrm{C}\right.$ and $3 \mathrm{kbar}$; Helt et al. 2014). Inferred physico-chemical conditions are schematically represented as stars for the non-altered metamorphic assemblage (purple), and for the distal (green) and proximal (orange) alteration zones. The arrow indicates the proposed activity gradient between the hydrothermal pathway and the host-rock. The apparent increase in the activity of aFe $e^{2+} / a^{2} \mathrm{H}^{+}$is interpreted to reflect decreasing sulfur content (a proxy for pyritization) with distance from the hydrothermal corridors. 

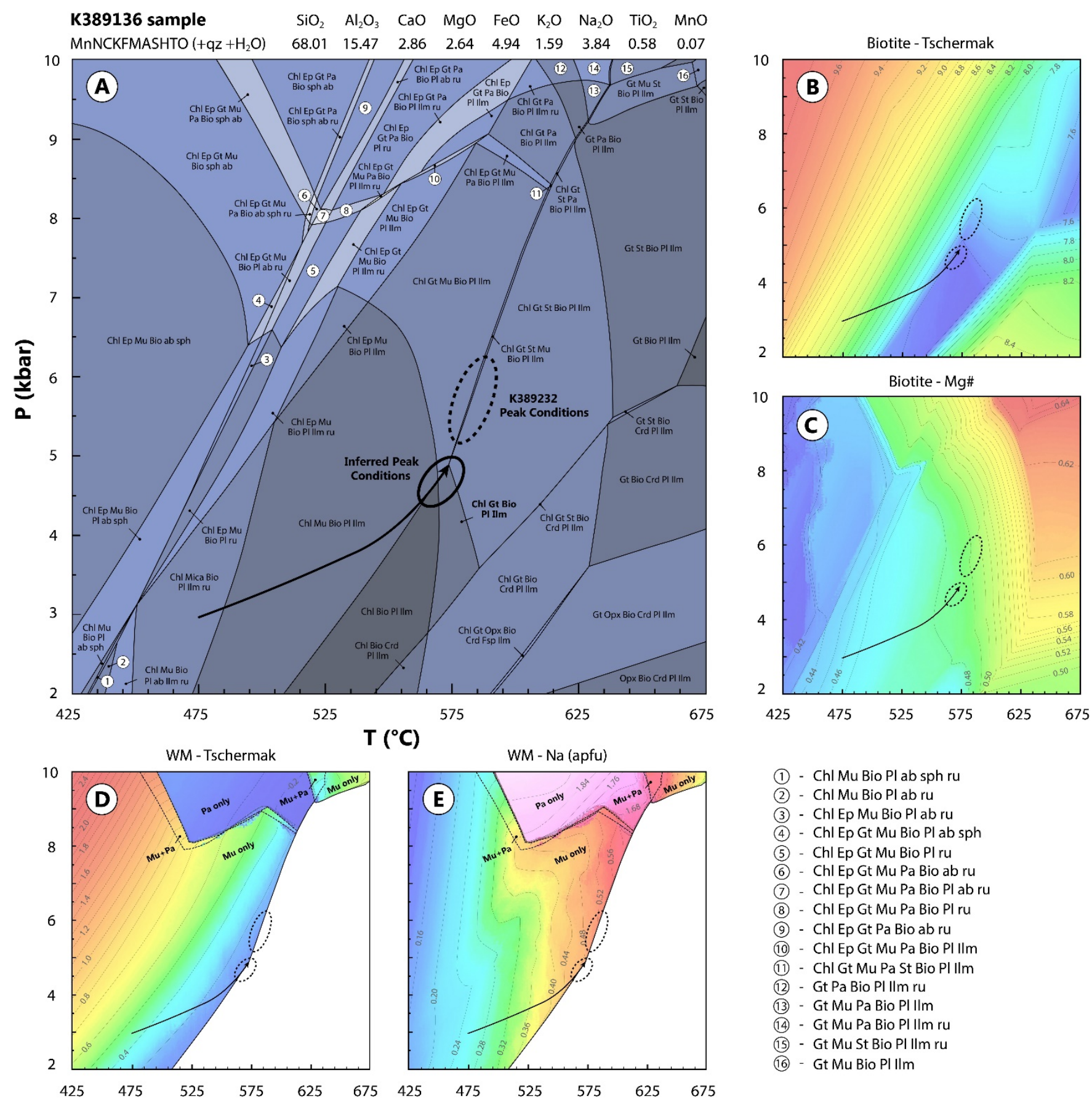

Figure 21: A: P-T Pseudosection constructed for a typical Pontiac Group greywacke (sample K389136) in the MnNCKFMASHTO system. The plain ellipse corresponds to the inferred peak metamorphic conditions (the dotted ellipse refers to the inferred peak conditions in sample K389232; see Fig.22). The arrow represents the proposed surficial metamorphic gradient along the $P_{2}$ section southwards (see location in Fig. 12A). B-C: Calculated

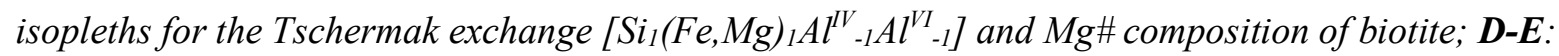

Compositional isopleths for the Tschermak exchange and Na content of white mica. Mineral abbreviations: ab: albite; bio: biotite; chl: chlorite; crd: cordierite; ep: epidote; gt: garnet; ilm: ilmenite; mu: muscovite; opx: orthopyroxene; pa: paragonite; pl: plagioclase; qz: quartz; ru: rutile; sph: titanite; st: staurolite. 

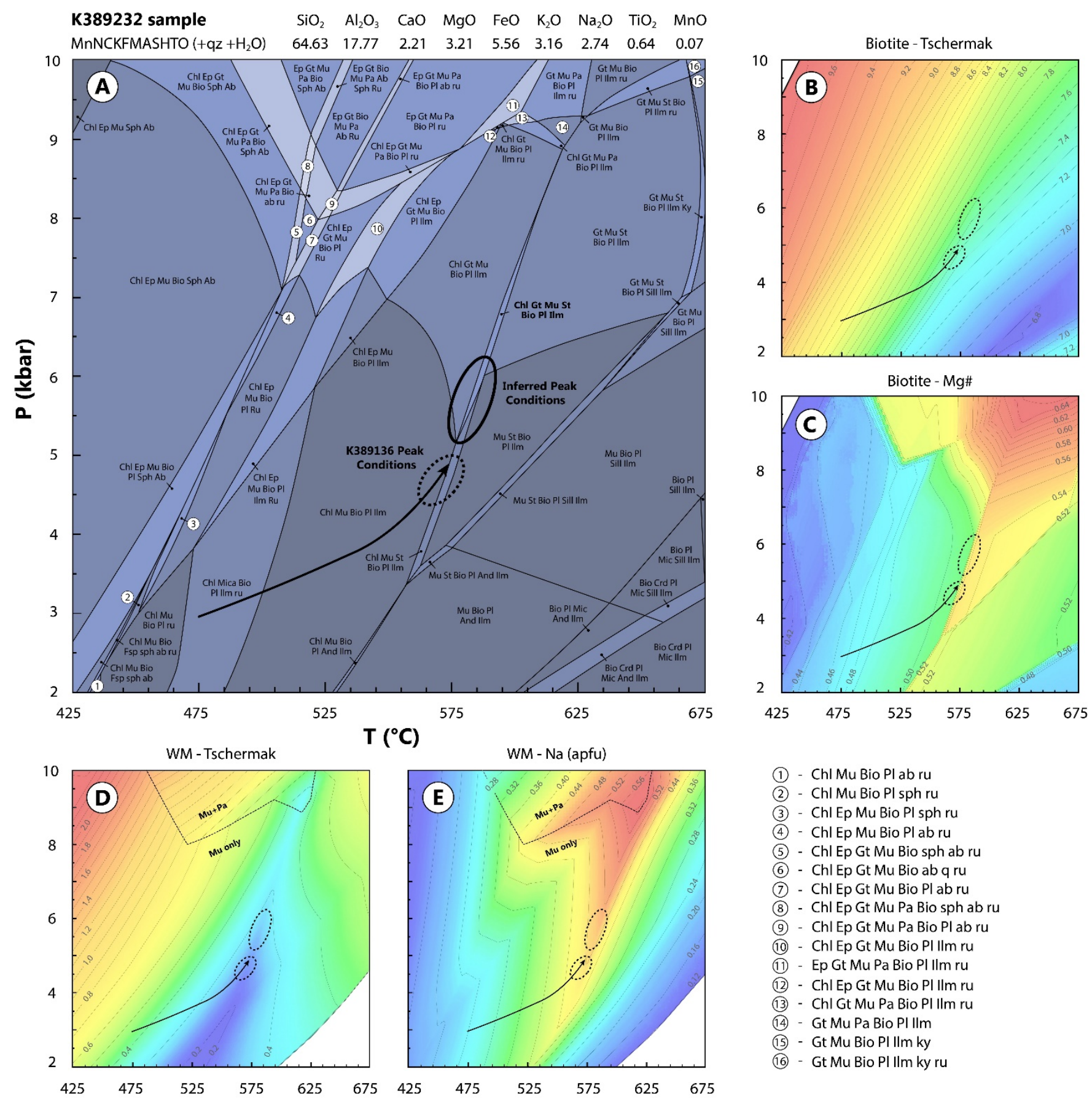

(1) - Chl Mu Bio Pl ab ru

(2) - Chl Mu Bio PI sph ru

(3) - Chl Ep Mu Bio PI sph ru

(4) - Chl Ep Mu Bio Pl ab ru

(5) - Chl Ep Gt Mu Bio sph ab ru

(6) - Chl Ep Gt Mu Bio ab q ru

(7) - Chl Ep Gt Mu Bio Pl ab ru

(8) - Chl Ep Gt Mu Pa Bio sph ab ru

(9) - Chl Ep Gt Mu Pa Bio Pl ab ru

(10) - ChI Ep Gt Mu Bio PI IIm ru

(11) - Ep Gt MuPa Bio PI Ilm ru

(12) - Chl Ep Gt Mu Bio PI Ilm ru

(13) - Chl Gt Mu Pa Bio PI Ilm ru

(14) - Gt Mu Pa Bio PI IIm

(15) - Gt Mu Bio PI IIm ky

(16) - Gt Mu Bio PI Ilm ky ru

Figure 22: A: P-T Pseudosection constructed for a typical Pontiac Group mudstone (sample K389232) in the MnNCKFMASHTO system. The plain ellipse corresponds to the inferred peak metamorphic conditions (the dotted ellipse refers to the inferred peak conditions in sample K389136; see Fig.21). The arrow represents the proposed surficial metamorphic gradient along the $P_{2}$ section southwards (see location in Fig. 12A). B-C: Calculated isopleths for the Tschermak exchange $\left[\mathrm{Si}_{1}(\mathrm{Fe}, \mathrm{Mg})_{1} \mathrm{Al}^{I V}{ }_{-1} \mathrm{Al} \mathrm{I}_{-1}\right]$ and $\mathrm{Mg} \#$ composition of biotite; D-E:

Compositional isopleths for the Tschermak exchange and Na content of white mica. Mineral abbreviations are identical to those used in Fig.21. 
Table 1: Representative biotite compositions from Pontiac Group metasedimentary rocks in the Canadian Malartic district (microprobe analysis).

\begin{tabular}{|c|c|c|c|c|c|c|c|c|c|c|}
\hline \multirow{2}{*}{$\begin{array}{l}\text { Alteration } \\
\text { Metamorphic Zone } \\
\text { Biotite Generation }\end{array}$} & \multirow{2}{*}{\multicolumn{2}{|c|}{$\begin{array}{c}\begin{array}{c}\text { Proximal Alteration } \\
\text { Biotite Zone }\end{array} \\
\text { Alteration biotite }\end{array}$}} & \multirow{2}{*}{\multicolumn{2}{|c|}{$\begin{array}{c}\begin{array}{c}\text { Distal Alteration } \\
\text { Biotite Zone }\end{array} \\
\text { Alteration biotite }\end{array}$}} & \multicolumn{2}{|c|}{$\begin{array}{l}\text { Least Altered } \\
\text { Biotite Zone }\end{array}$} & \multicolumn{2}{|c|}{$\begin{array}{l}\text { Least Altered } \\
\text { Garnet Zone }\end{array}$} & \multicolumn{2}{|c|}{$\begin{array}{l}\text { Least Altered } \\
\text { Staurolite Zone }\end{array}$} \\
\hline & & & & & $\mathrm{S}_{1}$ biotite & $\mathrm{S}_{2}$ biotite & $\mathrm{S}_{1}$ biotite & $\mathrm{S}_{2}$ biotite & $\mathrm{S}_{2}$ biotite & $\mathrm{S}_{2}$ biotite \\
\hline Sample & K389202 & K389918 & K389926 & K389016 & D2-149.0 & D2-149.0 & K389608 & K389608 & K389232 & D11-106.5 \\
\hline Drill Hole & CM07-1216 & CM07-1578 & CM07-1578 & CM07-1705 & CD08-D2 & CD08-D2 & Outcrop & Outcrop & CD08-D10 & CD08-D11 \\
\hline (in wt.\%) & 41.13 & 39.47 & 37.83 & 38.13 & 35.96 & 36.02 & 35.79 & 35.97 & 36.12 & 36.51 \\
\hline $\mathrm{TiO}_{2}$ & 0.96 & 1.51 & 1.64 & 2.11 & 1.62 & 1.64 & 1.46 & 1.53 & 1.67 & 1.49 \\
\hline $\mathrm{Al}_{2} \mathrm{O}_{3}$ & 14.96 & 15.96 & 16.66 & 15.37 & 18.04 & 17.93 & 19.59 & 19.45 & 19.72 & 19.79 \\
\hline $\mathrm{FeO}^{*}$ & 4.11 & 8.66 & 13.34 & 12.74 & 17.45 & 17.62 & 17.59 & 17.85 & 17.14 & 16.29 \\
\hline $\mathrm{MnO}$ & 0.09 & 0.10 & 0.21 & 0.25 & 0.17 & 0.18 & 0.18 & 0.18 & 0.11 & 0.06 \\
\hline $\mathrm{MgO}$ & 23.19 & 19.15 & 15.18 & 16.32 & 11.55 & 11.68 & 11.58 & 11.45 & 11.26 & 11.75 \\
\hline $\mathrm{CaO}$ & $<0.03$ & 0.10 & $<0.03$ & $<0.03$ & $<0.03$ & $<0.03$ & $<0.03$ & $<0.03$ & $<0.04$ & $<0.03$ \\
\hline $\mathrm{Na}_{2} \mathrm{O}$ & 0.05 & 0.04 & $<0.03$ & 0.04 & 0.09 & $<0.03$ & 0.17 & 0.17 & 0.22 & 0.30 \\
\hline $\mathrm{K}_{2} \mathrm{O}$ & 10.36 & 10.57 & 10.34 & 9.85 & 9.33 & 9.45 & 8.74 & 9.05 & 9.03 & 9.81 \\
\hline $\mathrm{BaO}$ & $<0.05$ & $<0.05$ & $<0.05$ & 0.06 & 0.19 & 0.20 & 0.12 & 0.13 & 0.17 & 0.20 \\
\hline $\mathrm{Cr}_{2} \mathrm{O}_{3}$ & 0.14 & 0.12 & $<0.12$ & 0.15 & 0.11 & 0.11 & $<0.09$ & 0.09 & $<0.56$ & $<0.56$ \\
\hline $\mathrm{ZrO}_{2}$ & $<0.05$ & $<0.06$ & $<0.06$ & $<0.06$ & $<0.06$ & $<0.06$ & $<0.05$ & $<0.06$ & $<0.06$ & $<0.06$ \\
\hline $\mathrm{F}$ & 2.01 & 0.50 & 0.54 & 0.65 & 0.19 & 0.20 & 0.22 & 0.27 & 0.21 & 0.20 \\
\hline $\mathrm{Cl}$ & $<0.01$ & $<0.01$ & $<0.01$ & $<0.01$ & $<0.01$ & $<0.01$ & $<0.01$ & $<0.01$ & $<0.01$ & $<0.01$ \\
\hline $\mathrm{O}=\mathrm{F}, \mathrm{Cl}$ & 0.85 & 0.21 & 0.23 & 0.27 & 0.08 & 0.08 & 0.09 & 0.11 & 0.09 & 0.08 \\
\hline Total & 96.20 & 95.99 & 95.64 & 95.44 & 94.63 & 94.98 & 95.43 & 96.03 & 95.67 & 96.33 \\
\hline \multicolumn{11}{|c|}{ Atoms per formula unit calculated on the basis of $20 \mathrm{O}+4(\mathrm{OH}, \mathrm{F}, \mathrm{Cl})$} \\
\hline $\mathrm{Si}$ & 5.72 & 5.67 & 5.59 & 5.61 & 5.47 & 5.46 & 5.37 & 5.37 & 5.40 & 5.41 \\
\hline $\mathrm{Al}^{\mathrm{IV}}$ & 2.28 & 2.33 & 2.41 & 2.39 & 2.53 & 2.54 & 2.63 & 2.63 & 2.60 & 2.59 \\
\hline $\mathrm{Al}^{\mathrm{VI}}$ & 0.17 & 0.37 & 0.49 & 0.44 & 0.70 & 0.67 & 0.83 & 0.80 & 0.87 & 0.87 \\
\hline $\mathrm{Fe}$ & 0.48 & 1.04 & 1.65 & 1.57 & 2.22 & 2.23 & 2.21 & 2.23 & 2.14 & 2.02 \\
\hline $\mathrm{Mg}$ & 4.81 & 4.10 & 3.34 & 3.37 & 2.62 & 2.64 & 2.59 & 2.55 & 2.51 & 2.60 \\
\hline $\mathrm{Ti}$ & 0.11 & 0.16 & 0.18 & 0.23 & 0.18 & 0.19 & 0.16 & 0.17 & 0.19 & 0.17 \\
\hline $\mathrm{Mn}$ & 0.01 & 0.01 & 0.03 & 0.03 & 0.02 & 0.02 & 0.02 & 0.02 & 0.01 & 0.01 \\
\hline $\mathrm{Cr}$ & 0.02 & 0.01 & - & 0.02 & 0.01 & 0.01 & - & 0.01 & - & - \\
\hline K & 1.84 & 1.94 & 1.95 & 1.85 & 1.81 & 1.83 & 1.67 & 1.73 & 1.72 & 1.86 \\
\hline $\mathrm{Na}$ & 0.01 & 0.01 & - & 0.01 & 0.03 & - & 0.05 & 0.05 & 0.06 & 0.09 \\
\hline $\mathrm{Ca}$ & - & 0.02 & - & - & - & - & - & - & - & - \\
\hline $\mathrm{Ba}$ & - & - & - & 0.00 & 0.01 & 0.01 & 0.01 & 0.01 & 0.01 & 0.01 \\
\hline $\mathrm{OH}^{* *}$ & 3.12 & 3.77 & 3.75 & 3.70 & 3.91 & 3.90 & 3.90 & 3.87 & 3.90 & 3.91 \\
\hline $\mathrm{F}$ & 0.88 & 0.23 & 0.25 & 0.30 & 0.09 & 0.10 & 0.10 & 0.13 & 0.10 & 0.09 \\
\hline $\mathrm{Cl}$ & - & - & - & - & - & - & - & - & - & - \\
\hline $\mathrm{X}_{\mathrm{Mg}}$ & 0.91 & 0.80 & 0.67 & 0.68 & 0.54 & 0.54 & 0.54 & 0.53 & 0.54 & 0.56 \\
\hline $\log \left(f \mathrm{H}_{2} \mathrm{O}\right) /(f \mathrm{HF})$ & 5.41 & 5.88 & 5.64 & 5.56 & 5.91 & 5.88 & 5.83 & 5.73 & 5.83 & 5.89 \\
\hline
\end{tabular}

* Total iron expressed as $\mathrm{FeO}$

** OH is calculated assuming full site occupancy 
Table 2: Representative white mica compositions from Pontiac Group metasedimentary rocks in the Canadian Malartic district (microprobe analysis).

\begin{tabular}{|c|c|c|c|c|c|c|c|c|c|c|}
\hline \multirow{2}{*}{$\begin{array}{l}\begin{array}{l}\text { Alteration } \\
\text { Metamorphic Zone }\end{array} \\
\text { White Mica Generation }\end{array}$} & \multirow{2}{*}{\multicolumn{2}{|c|}{$\begin{array}{c}\begin{array}{c}\text { Proximal Alteration } \\
\text { Biotite Zone }\end{array} \\
\text { Alteration WM }\end{array}$}} & \multirow{2}{*}{\multicolumn{2}{|c|}{$\begin{array}{c}\begin{array}{c}\text { Distal Alteration } \\
\text { Biotite Zone }\end{array} \\
\text { Alteration WM }\end{array}$}} & \multicolumn{2}{|c|}{$\begin{array}{l}\text { Least Altered } \\
\text { Biotite Zone }\end{array}$} & \multicolumn{2}{|c|}{$\begin{array}{l}\text { Least Altered } \\
\text { Garnet Zone }\end{array}$} & \multicolumn{2}{|c|}{$\begin{array}{l}\text { Least Altered } \\
\text { Staurolite Zone }\end{array}$} \\
\hline & & & & & $\mathrm{S}_{1} \mathrm{WM}$ & $\mathrm{S}_{2} \mathrm{WM}$ & $\mathrm{S}_{1} \mathrm{WM}$ & $\mathrm{S}_{2} \mathrm{WM}$ & $\mathrm{S}_{2} \mathrm{WM}$ & $\mathrm{S}_{2} \mathrm{WM}$ \\
\hline Sample & K389929 & $986-152.7$ & K389926 & K389016 & D4-40.00 & D4-40.00 & K389608 & K389608 & K389232 & D11-106.5 \\
\hline Drill Hole & CM07-1578 & CM06-986 & CM07-1578 & CM07-1705 & CD08-D4 & CD08-D4 & Outcrop & Outcrop & CD08-D10 & CD08-D11 \\
\hline (in wt.\%) & 47.21 & 48.64 & 47.79 & 47.39 & 45.18 & 45.97 & 46.63 & 46.73 & 46.15 & 46.00 \\
\hline $\mathrm{TiO}_{2}$ & 0.96 & 1.13 & 0.98 & 1.15 & 0.33 & 0.44 & 0.43 & 0.45 & 0.40 & 0.38 \\
\hline $\mathrm{Al}_{2} \mathrm{O}_{3}$ & 30.62 & 31.15 & 30.45 & 31.91 & 35.30 & 34.85 & 34.90 & 34.92 & 35.91 & 36.51 \\
\hline $\mathrm{FeO}^{*}$ & 2.94 & 1.96 & 3.12 & 3.08 & 2.19 & 2.08 & 1.13 & 1.12 & 0.92 & 0.91 \\
\hline $\mathrm{MnO}$ & $<0.05$ & $<0.05$ & $<0.05$ & $<0.05$ & $<0.05$ & $<0.05$ & $<0.05$ & $<0.05$ & $<0.05$ & $<0.05$ \\
\hline $\mathrm{MgO}$ & 2.25 & 2.53 & 2.28 & 1.97 & 0.62 & 0.88 & 0.93 & 0.96 & 0.70 & 0.64 \\
\hline $\mathrm{CaO}$ & $<0.03$ & 0.05 & $<0.03$ & $<0.03$ & 0.04 & 0.03 & $<0.03$ & $<0.03$ & $<0.03$ & $<0.03$ \\
\hline $\mathrm{Na}_{2} \mathrm{O}$ & 0.19 & 0.15 & 0.21 & 0.18 & 0.59 & 0.59 & 0.80 & 0.79 & 1.24 & 1.43 \\
\hline $\mathrm{K}_{2} \mathrm{O}$ & 11.10 & 10.92 & 11.20 & 10.69 & 10.23 & 10.06 & 9.79 & 9.95 & 9.26 & 9.54 \\
\hline $\mathrm{BaO}$ & 0.10 & 0.08 & 0.22 & 0.24 & 0.75 & 0.69 & 0.41 & 0.43 & 0.53 & 0.68 \\
\hline $\mathrm{Cr}_{2} \mathrm{O}_{3}$ & 0.17 & 0.44 & $<0.11$ & 0.30 & $<0.08$ & $<0.08$ & $<0.08$ & $<0.08$ & $<0.56$ & $<0.50$ \\
\hline $\mathrm{ZrO}_{2}$ & $<0.05$ & $<0.06$ & $<0.05$ & $<0.05$ & $<0.05$ & $<0.05$ & $<0.05$ & $<0.05$ & $<0.06$ & $<0.06$ \\
\hline F & $<0.14$ & $<0.13$ & 0.14 & $<0.12$ & $<0.14$ & 0.14 & $<0.14$ & $<0.14$ & $<0.16$ & $<0.15$ \\
\hline $\mathrm{Cl}$ & $<0.01$ & $<0.01$ & $<0.01$ & $<0.01$ & $<0.01$ & $<0.01$ & $<0.01$ & $<0.01$ & $<0.01$ & $<0.01$ \\
\hline $\mathrm{O}=\mathrm{F}, \mathrm{Cl}$ & 0.00 & 0.01 & 0.06 & 0.03 & 0.00 & 0.06 & 0.00 & 0.04 & 0.05 & 0.00 \\
\hline Total & 95.56 & 97.05 & 96.47 & 96.97 & 95.32 & 95.70 & 95.10 & 95.42 & 95.75 & 96.26 \\
\hline \multicolumn{11}{|c|}{ Atoms per formula unit calculated on the basis of $20 \mathrm{O}+4(\mathrm{OH}, \mathrm{F}, \mathrm{Cl})$} \\
\hline $\mathrm{Si}$ & 6.36 & 6.40 & 6.39 & 6.29 & 6.08 & 6.14 & 6.21 & 6.21 & 6.13 & 6.08 \\
\hline $\mathrm{Al}^{\mathrm{IV}}$ & 1.64 & 1.60 & 1.61 & 1.71 & 1.92 & 1.86 & 1.79 & 1.79 & 1.87 & 1.92 \\
\hline $\mathrm{Al}^{\mathrm{VI}}$ & 3.22 & 3.23 & 3.19 & 3.27 & 3.68 & 3.62 & 3.69 & 3.68 & 3.76 & 3.76 \\
\hline $\mathrm{Fe}$ & 0.33 & 0.22 & 0.35 & 0.34 & 0.25 & 0.23 & 0.13 & 0.12 & 0.10 & 0.10 \\
\hline $\mathrm{Mg}$ & 0.45 & 0.50 & 0.45 & 0.39 & 0.13 & 0.18 & 0.18 & 0.19 & 0.14 & 0.13 \\
\hline $\mathrm{Ti}$ & 0.10 & 0.11 & 0.10 & 0.11 & 0.03 & 0.04 & 0.04 & 0.05 & 0.04 & 0.04 \\
\hline $\mathrm{Mn}$ & - & - & - & - & - & - & - & - & - & - \\
\hline $\mathrm{Cr}$ & 0.01 & 0.05 & - & 0.03 & - & - & - & - & - & - \\
\hline $\mathrm{K}$ & 1.91 & 1.83 & 1.91 & 1.81 & 1.76 & 1.71 & 1.66 & 1.69 & 1.57 & 1.61 \\
\hline $\mathrm{Na}$ & 0.05 & 0.04 & 0.05 & 0.05 & 0.16 & 0.15 & 0.21 & 0.20 & 0.32 & 0.37 \\
\hline $\mathrm{Ca}$ & - & 0.01 & - & - & 0.01 & 0.00 & - & - & - & - \\
\hline $\mathrm{Ba}$ & 0.01 & 0.00 & 0.01 & 0.01 & 0.04 & 0.04 & 0.02 & 0.02 & 0.03 & 0.04 \\
\hline $\mathrm{OH}^{* *}$ & 4.00 & 4.00 & 3.94 & 4.00 & 4.00 & 3.94 & 4.00 & 4.00 & 4.00 & 4.00 \\
\hline $\mathrm{F}$ & - & - & 0.06 & - & - & 0.06 & - & - & - & - \\
\hline $\mathrm{Cl}$ & - & - & - & - & - & - & - & - & - & - \\
\hline$X_{M g}$ & 0.58 & 0.70 & 0.57 & 0.53 & 0.37 & 0.43 & 0.59 & 0.60 & 0.57 & 0.56 \\
\hline
\end{tabular}

* Total iron expressed as $\mathrm{FeO}$

** OH is calculated assuming full site occupancy 